Augusto Cesar Crivellari

\title{
Caracterização estrutural das hemiceluloses de paredes celulares de cana-de-açúcar
}

\section{Characterization of the sugarcane cell wall hemicelluloses}

São Paulo 
2012

Augusto Cesar Crivellari

Caracterização estrutural das hemiceluloses de paredes celulares de cana-de-açúcar

\section{Charaterization of the sugarcane cell wall hemiceluloses}

\section{VERSÃO ORIGINAL CORRIGIDA \\ O ORIGINAL ENCONTRA-SE DISPONÍVEL NA BIBLIOTECA DO IB-USP}

Dissertação apresentada ao Instituto de

Biociências da Universidade de São Paulo, para a obtenção de Título de Mestre em Ciências Biológicas, na Área de Botânica.

Orientador: Prof. Dr. Marcos Silveira Buckeridge

São Paulo 
Crivellari, Augusto Cesar

Caracterização estrutural das hemiceluloses de paredes celulares de cana-de-açúcar.

$93 \mathrm{p}$.

Dissertação (Mestrado) - Instituto de Biociências da Universidade de São Paulo. Departamento de Botânica.

1. Arabinoxilano 2. Xiloglucano 3. Hemiceluloses 4. Parede Celular 5. Cana-de-açúcar 6. Etanol celulósico. Universidade de São Paulo. Instituto de Biociências. Departamento de Botânica.

2012

\section{Comissão Julgadora:}

Prof.(a) $\operatorname{Dr}(a)$ :

Prof.(a) $\operatorname{Dr}(a)$ :

Prof. Dr. Marcos Silveira Buckeridge

Orientador 
Dedico esse trabalho,

Aos meus pais, pelos ENORMES esforços dedicados a mim e meus estudos;

Ao meu irmão, pela plena disposição em ajudar e a constante torcida;

À Mafinha minha vó madrinha;

Ao Junião pelo espelho e inspiração;

E à minha linda Thalita por toda ajuda. Sem ela a vida teria menos graça. 
"O homem é do tamanho do seu sonho..."

Livro do Desassossego, Fernando Pessoa 


\section{Agradecimentos}

Ao Instituto de Biociências, em Especial ao Departamento de Botânica IB-USP;

À FAPESP pela Bolsa de Estudo concedida;

Ao Professor Dr. Marcos Silveira Buckeridge pelos constantes conselhos, pelos exemplos e pela amizade;

À Professora Dra. Magdalena Rossi pela ajuda na qualificação;

Ao Professor Sandro Marana pelo auxílio com a expressão da XTH;

À inestimável ajuda do time do CTBE, em especial ao Dr. Roberto Ruller, que também contribuiu com a qualificação;

Ao Sávio pela grande ajuda com as sequência da XTH;

Ao time do Laboratório de Carboidratos do laboratório de Cambridge, em especial ao Prof. Dr. Paul Dupree;

À Dra. Theodora Thryphona, ou Dorita, pela enorme ajuda com os experimentos de espectrometria e pela amizade;

À todo o time do Lafieco, em especial as meninas (Amanda, Bru, Cris, Débora, Drika, Eglee, Eveline e Vivi) e o Wandeco que tanto me apoiaram e me ajudaram;

Ao Guilherme M. Q. Cruz, Musquito, pela ajuda a todo momento e pela amizade;

A todos amigos que participaram, conscientemente ou não, e contribuíram com esse trabalho, oferecendo amizade e apoio a todo momento. 


\section{Sumário}

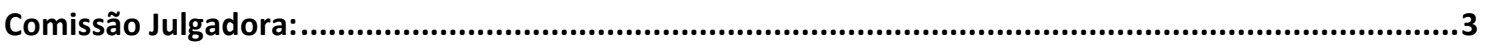

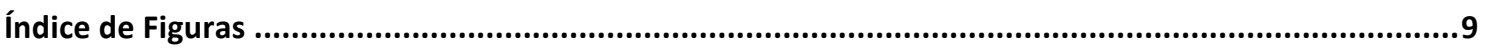

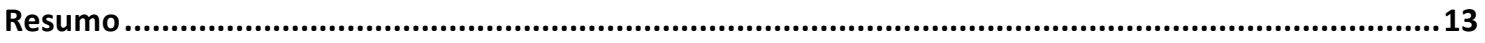

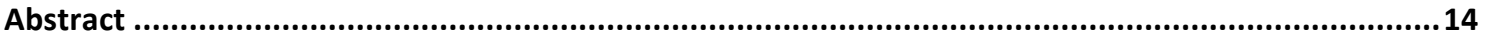

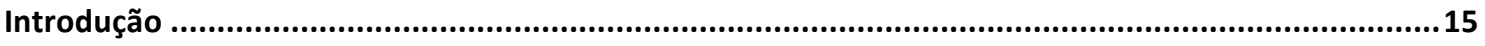

Cana-de-açúcar: do Bioetanol de sacarose à quarta geração..................................................... 15

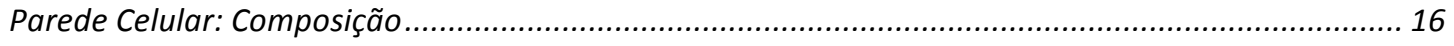

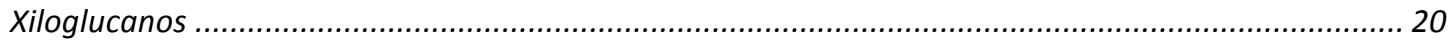

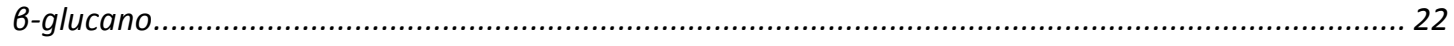

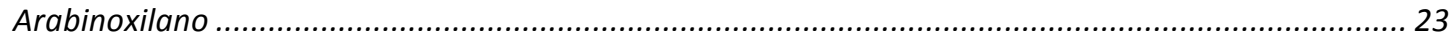

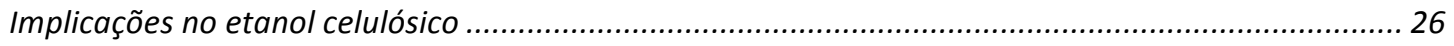

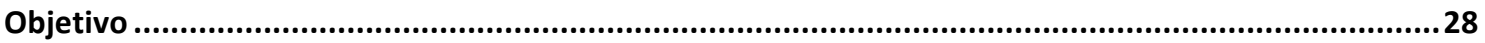

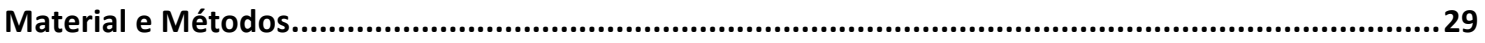

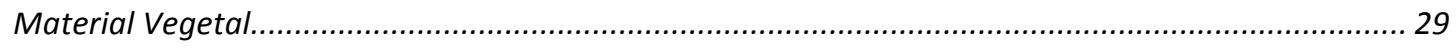

Estrutura fina das principais hemiceluloses da parede celular de cana-de-açúcar ........................... 29

Extração da parede celular de colmo e folha de cana-de-açúcar.................................................... 30

Análise de oligossacarídeos por Cromatografia Aniônica de Alta Performance com deteç̧ão por Amperométrica Pulsada (HPAEC-PAD) ...................................................................................... 31

Fracionamento da parede celular de colmo de cana-de-açúcar e análise da estrutura fina do xiloglucano e arabinoxilano.

Análise dos oligossacarídeos provenientes da digestão enzimática das frações $1 M$ e $4 M$ da parede de celular de colmo de cana-de-açúcar com xilanase e celulase por espectrometria de massas (MALDITOF).

Alíquotas das misturas dos oligossacarídeos provenientes da digestão enzimática das frações $1 \mathrm{M}$ e $4 \mathrm{M}$ do fracionamento químico de colmo de cana-de-açúcar foram analisados em HPAEC-PAD (seguindo a metodologia descrita no item Análise de oligossacarídeos por Cromatografia Aniônica de Alta Performance com deteç̧ão por Amperométrica Pulsada (HPAEC-PAD)) antes do encaminhamento das amostras ao MALDI-TOF. Em conjunto, as duas técnicas possibilitaram a identificação dos principais oligossacarídeos da mistura.

Análise oligossacarídeos provenientes da digestão enzimática das frações $1 \mathrm{M}$ e $4 \mathrm{M}$ da parede de celular de colmo de cana-de-açúcar com xilanase por eletroforese de carboidratos em gel de poliacrilamida (PACE).

Digestão enzimática sequencial utilizando liquenase e xilanase em parede celular de colmo de canade-açúcar. 
Comparação da composição e estrutura da parede celular de colmo e folha de cana-de-açúcar......

Digestão enzimática sequencial utilizando liquenase e xilanase em parede celular de colmo de canade-açúcar.

Análise estrutural dos oligossacarídeos de xiloglucano e arabinoxilanos obtidos por digestão enzimática por espectrométrica de massa (MALDI-TOF).....

Análise estrutural dos oligossacarídeos produzidos pela digestão enzimática das frações 1 e $4 M$ por

PACE .

Discussão

Estrutura fina da Parede de cana-de-açúcar: diferenças entre folha e colmo e possíveis consequências biotecnológicas. Xiloglucano, b-glucano e arabinoxilano. ............................................................ 69

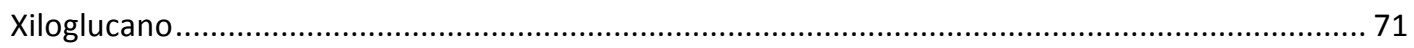

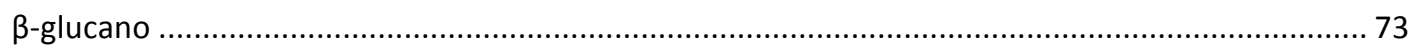

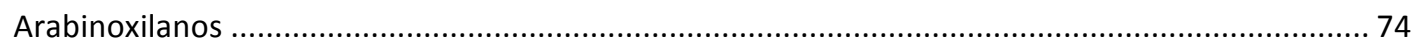

Interações entre hemiceluloses e a limitações para hidrólise enzimática ....................................... 82

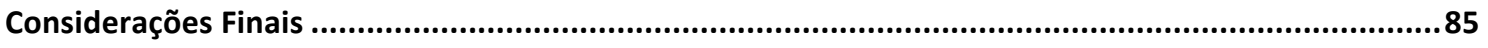

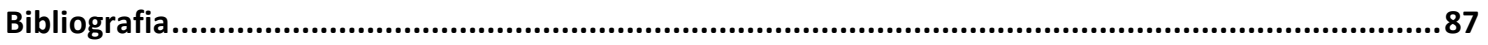

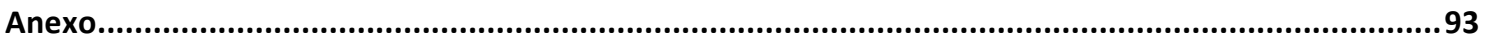




\section{Índice de Figuras}

Figura 1 - Arquitetura das paredes celulares dos tipos I e II segundo as ideias de Nick Carpita e David Gibeaut em 1993. Na parede do tipo I, o domínio celulose-hemicelulose é composto por xiloglucanos com diferentes tipos de ramificações que the conferem diferentes níveis de adesão às microfibrilas (tons de laranja). A proporção entre celulose, hemicelulose e pectinas é equilibrada. Na parede do tipo II, a principal hemicelulose é o arabinoxilano (azul). Acredita-se que quando ele é sintetizado as ramificações com arabinose são retiradas quando na parede celular. O polímero menos ramificado adere fortemente às microfibrilas (azul claro), enquanto o mais ramificado adere fracamente (azul escuro). Diferentemente dos xiloglucanos, os arabinoxilanos parecem se ligar entre si por compostos fenólicos, que são mais abundantes nas paredes celulares do tipo II. Nas paredes do tipo II, a proporção de pectina é menor do que celulose e hemicelulose. (Fonte: adaptado de Buckeridge et al., 2008).

Figura 2 - Oligossacarídeos típicos obtidos através de hidrólise enzimática de xiloglucanos com celulase. Cadeia de glucoses (esferas azuis), com ramificações com xiloses (esferas vermelhas) e estas com galactoses terminais (esferas verdes). A nomenclatura do oligossacarídeo sempre se dá pelo último sacarídeo em cada subunidade, ou seja, (A) XXXG, (B) XLXG, (C) XXLG e por fim (D) XLLG, respectivamente (Fry et al., 1993)... 22

Figura 3 - Esquema exemplificando a ligação entre os resíduos de glucose em uma molécula de $\beta$ glucano. Ligações lineares $\beta-1 \rightarrow 4$ são interrompidas por ligações $\beta-1 \rightarrow 3$, as quais mudam o sentido da molécula, como exemplificado após o quinto resíduo acima (ligações $\beta-1 \rightarrow 3$ indicadas por setas)

Figura 4 - Principais ramificações dos arabinoxilanos de paredes celulares de gramíneas. As cadeias de xilano são representadas pelas linhas pontilhada e os resíduos de arabinose (Ara) podem apresentar: grupos acetila (1), éster de ácido ferúlico ligado ao arabinoxilano (2), arabinose ligada diretamente à lignina (3) ou diferulatos formando ligações cruzadas entre polissacarídeos (4) e ésteres de ácido ferúlico ligados à lignina (5). Fonte: Buanafina (2009). 24

Figura 5 - Concentração de acetato de sódio ao longo de uma corrida visando a separação dos oligossacarídeos e a posterior detecção no amperômetro. Sistema HPAED-PAD, Dionex® ICS-3000, com coluna CarboPac PA-100 .....32

Figura 6 - Digestões de parede celular de colmo e folha, com celulase (B), liquenase (C) ou xilanase (D). (A) controle sem adição de enzima. (B), com a atividade da celulase, são observados fragmentos que podem indicar a presença de xiloglucano: (a) glucose, (b) isoprimeverose, (c) celobiose, (d) oligossacarídeo XXG, $\left({ }^{*}\right)$ picos de retenção semelhantes à digestão com xilanase entre 7,5 a 12,5 minutos. (C), digestão com liquenase observa-se os 
picos de (e) trissacarídeo, (f) tetrassacarídeo e (g) pentassacarídeos de glucose. (D), a digestão com xilanase produziu uma serie homóloga de oligossacarídeos que lembram fragmentos de xilanos. As digestões ocorreram em pH 5.0, em tampão acetato de amônio e com 0,5U de enzima. A reação era interrompida com $5 \mathrm{~min}$ de fervura. Os cromatogramas foram obtidos em um HPAEC-PAD Dionex® ICS-3000

Figura 7 - Injeção de padrão de isoprimeverose indicando um pico preponderante em 5,567 min. O perfil cromatográfico foi obtido em HPAECPAD Dionex® ICS-3000, no mesmo programa em que foram corridas todas as outras amostras.

Figura 8 - Coinjeção de glucose e isoprimeverose com amostra de digestão de parede celular de colmo digerido com celulase. Esta coinjeção visou dar suporte à afirmação de que os picos com tempos de retenção de 3,74 (a) e 5,54 (b) são glucose e isoprimeverose respectivamente. O cromatograma foi obtido em um HPAEC-PAD Dionex® ICS-3000, no mesmo programa em que foram corridas todas as outras amostras.

Figura 9 - Controles do experimento da digestão sequencial. Letra ${ }_{1}\left(A_{1}, B_{1}, C_{1}\right.$ e $\left.D_{1}\right)$ corresponde à digestão de $0-24$ horas; Letra $\left(A_{2}, B_{2}, C_{2}\right.$ e $\left.D_{2}\right)$ corresponde à digestão de 24-48 horas. (A) ausência de enzima em ambos os ciclos de digestão; (B) ambos os ciclos de digestão enzimática com Liquenase; (C) ambos os ciclos de digestão enzimática com Xilanase; (D) ambos os ciclos de digestão enzimática com Liquenase e Xilanase concomitantemente. (a) trissacarídeo típico de $\beta$-glucano, (b) tetrassacarídeo típico de $\beta$-glucano e (c) pentassacarídeo típico de $\beta$-glucano. $(\rightarrow$ ) picos com tempo de retenção únicos do tratamento com lichanase e xilanase concomitante. As digestões ocorreram em pH 5.0, em tampão acetato de amônio e com 0,5U/mL de enzima (quando presente). Antes de uma nova enzima ser adicionada, a reação era interrompida com 5 minutos de fervura. Os cromatogramas foram obtidos por HPAEC-PAD Dionex® ICS-3000.

Figura 10 - Digestão seqüencial à amostra de parede celular de colmo de cana-de-açúcar. Letra ${ }_{1}\left(A_{1}, B_{1}, C_{1}\right.$ e $\left.D_{1}\right)$ corresponde à digestão de 0-24 horas; Letra $_{2}\left(A_{2}, B_{2}, C_{2}\right.$ e $\left.D_{2}\right)$ corresponde à digestão de 24-48 horas. (A) digestão seqüencial iniciada $(0-24 \mathrm{~h})$ com enzima Liquenase $\left(A_{1}\right)$, seguida $(24-48 \mathrm{~h})$ de digestão com Xilanase $\left(A_{2}\right)$; $(B)$ digestão seqüencial iniciada $(0-24 \mathrm{~h}) \mathrm{com}$ enzima Xilanase $\left(B_{1}\right)$, seguida (24-48h) de digestão com Liquenase $\left(B_{2}\right) .(\rightarrow)$ picos com tempo de retenção diferentes dos controles com uma única enzima, ou seja, picos novos. As digestões ocorreram em pH 5.0, em tampão acetato de amônio e com 0,5U/mL de enzima. Antes de uma nova enzima ser adicionada, a reação era interrompida com 5 minutos de fervura. Os cromatogramas foram obtidos por análise em HPAEC-PAD Dionex® ICS-3000. 
Figura 11 - Perfis cromatográficos das hidrólises enzimáticas das frações $1 \mathrm{M} \mathrm{e}$ $4 \mathrm{M}$ da parede celular de colmo de cana-de-açúcar com as enzimas xilanase (A e B) e celulase (C e D). (A) Perfil dos oligossacarídeos provenientes da digestão da fração $1 \mathrm{M}$ com Xilanase; (B) Perfil dos oligossacarídeos provenientes da digestão da fração 4M com Xilanase; (C) Perfil dos oligossacarídeos provenientes da digestão da fração $1 \mathrm{M}$ com Celulase; (D) Perfil dos oligossacarídeos provenientes da digestão da fração 4M com Celulase. (a) Oligossacarídeos com diversidade e intensidade diferentes entre (A) e (B); (b) Oligossacarídeos com diversidade e intensidade diferentes entre (C) e (D); (c), (d), (e) principais oligossacarídeos que apresentam diferenças de intensidade entre (C) e (D). 56

Figura 12 - Cromatogramas da espectrometria de massas (MALDI-TOF) das hidrólises enzimáticas das frações $1 \mathrm{M}$ e $4 \mathrm{M}$ da parede celular de colmo de cana-de-açúcar com as enzimas xilanase (A e B) e celulase (C e D). (A) Perfil das massas dos oligossacarídeos provenientes da digestão da fração $1 \mathrm{M} \mathrm{com}$ Xilanase, sendo os retângulos em sequência Pentose 5 até Pentose 14; (B) Perfil das massas dos oligossacarídeos provenientes da digestão da fração $4 \mathrm{M}$ com Xilanase, sendo os retângulos em sequência Pentose 4 até Pentose 9 ; (C) Perfil das massas dos oligossacarídeos provenientes da digestão da fração $1 \mathrm{M}$ com Celulase, sendo os retângulos em sequência XXG, XXGG; (D) Perfil das massas dos oligossacarídeos provenientes da digestão da fração $4 \mathrm{M} \mathrm{com}$ Celulase, sendo os retângulos em sequência XXG, XXGG, XXGGG/XLGG, $X X X G, X L X G / X X L G$ e XXXXG . Retângulos e Setas em A e B: massas mensuradas que variam, entre si, na forma de uma progressão aritmética, sempre com o acréscimo de 132 a massa anterior; Retângulo em C e D: massas mensuradas que não variam, na forma de uma progressão aritmética, ora a o acréscimo de 132, ora de 162 a massa anterior.

Figura 13 - Corrida preparativa de TLC. Local onde as bandas foram reveladas, visando determinar em que local a sílica deveria ser raspada para que se isolassem os oligossacarídeos. Digestão com xilanase da fração $4 \mathrm{M}$ da parede celular de colmo de cana-de-açúcar

Figura 14 - Cromatografia de troca aniônica de alta performance (HPAEACPAD) de cada uma das 6 bandas raspadas da TLC da digestão com xilanase da fração $1 \mathrm{M}$, Notar que a escala das bandas 4, 5 e 6 é 10 vezes menor que da banda 1, 2 e 3, para melhor visualização.

Figura 15 - Cromatografia de troca aniônica de alta performance (HPAEACPAD) de cada uma das 8 bandas raspada na TLC da digestão com xilanase da fração 4M. Notar que a escala das bandas 4, 5, 6, 7 e 8 é 2 vezes menor que da banda 1, 2 e 3, para melhor visualização.

Figura 17 - Gel de Poliacrilamida de PACE das bandas purificadas em TLC da hidrólise enzimática da fração 4M com Xilanase. (Ladder) Padrão de oligossacarídeos de xilano com número de resíduos conhecidos, variando de 1 
xilose a 6 xiloses; (Crude 4M) Fração 4M não digerida com a xilanase; (B1 a B8) Bandas purificadas em TLC da hidrólise enzimática da fração $1 \mathrm{M}$ com Xilanase, onde B1 migrou mais na placa de sílica (TLC), ou seja, ficou mais alta em relação a base e a B8 teve a menor migração na placa de sílica (TLC); Retângulo: oligossacarídeos das bandas "purificadas" com migração semelhante ao padrão de oligossacarídeos de xilano

Figura 18 - Análises em PACE das bandas purificadas em TLC B1, B3 e B4 das digestões das frações $1 \mathrm{M}$ e $4 \mathrm{M}$ com Xilanase submetidas a novas digestões com 2 arabinofuranosidases (família GH51 e GH62). (A) Pace das bandas B1 e B3 purificadas em TLC, provenientes da digestão da fração $1 \mathrm{M}$ com Xilanase; (B) Pace da banda B4 purificada em TLC, proveniente da digestão da fração $1 \mathrm{M}$ com Xilanase, e das bandas B1, B3 e B4 purificadas em TLC proveniente da digestão da fração $4 \mathrm{M}$ com Xilanase. Setas (A, E, G, I): bandas presentes na fração $1 \mathrm{M}$ ou $4 \mathrm{M}$ não digerida com as arabinofuranosidases (Bx undige), mas ausentes quando da presença de qualquer um das arabinofuranosidases (Bx gh51; $B x$ gh62); Retângulos (B, $C$, $D, F, H, K)$, Seta (J): bandas ausentes na fração $1 \mathrm{M}$ ou $4 \mathrm{M}$ não digerida com as arabinofuranosidases (Bx undige), mas presentes quando da presença de qualquer um das arabinofuranosidases (Bx gh51; Bx gh62). 68

Figura 19: Esquema de todos os experimentos realizados. 95 


\section{Resumo}

O Brasil, segundo maior produtor mundial de biocombustíveis, produz etanol a partir da extração e fermentação de sacarose de colmos de cana-de-açúcar. A utilização da energia presente nas ligações químicas entre os carboidratos da parede celular (celulose, hemiceluloses e pectina), das biomassas de folha e bagaço (hoje ambos considerados resíduos de produção), é uma possibilidade para o incremento, de cerca de 3 vezes o valor atual, na produção de etanol. O entendimento da estrutura química dos polissacarídeos da parede celular de cana-de-açúcar é imprescindível para que esta tecnologia seja desenvolvida. O presente trabalho teve como objetivo isolar as hemiceluloses de colmo de cana-de-açúcar e estudar as suas estruturas químicas. Para tal, utilizou-se AIR (Alcohol Insoluble Residue) - parede celular sem açúcar solúvel - de colmo e folha de cana-de-açúcar SP80-3280 em hidrólises enzimáticas com endo- $\beta$-xilanase, liquenase e celulase isoladamente ou em conjunto de forma a determinar a estrutura fina dos polímeros atacáveis por tais hidrolases. O AIR de colmo também foi submetido ao fracionamento da parede celular com oxalato de amônio, seguido de extrações com $1 \mathrm{M}$ e $4 \mathrm{M}$ de $\mathrm{NaOH}$ para a separação das hemiceluloses. Somente as frações $1 \mathrm{M}$ e $4 \mathrm{M}$ de $\mathrm{NaOH}$ foram analisadas, através de hidrólises com endo- $\beta$-xilanases, seguido da análise dos oligossacarídeos resultantes por HPAEC-PAD (High Performance Anionic Exchange Chromatography with Pulsed Amperometric Detection) e por espectrometria de massas MALDI-TOF. Paralelamente, grupos de oligossacarídeos provenientes de hidrólises do colmo com endo- $\beta$-xilanase foram isolados por cromatografia em camada delgada (TLC) preparativa e, em seguida, hidrolisados com a-arabinofuranosidases e analisados por PACE (Polyacrylamide Carbohydrate Electrophoresis) para o esclarecimento da estrutura fina de arabinoxilanos. Os resultados obtidos mostraram a presença de xiloglucano na fração $\mathrm{NaOH} 4 \mathrm{M}$ em pequena proporção, cerca de $3 \%$ da parede celular, sendo este xiloglucano de 2 tipos: estrutura fina típica de gramíneas (composta por glucose, e os oligossacarídeos isoprimeverose, XG, XXG, XXGG, XXGGG) e estrutura fina de eudicotiledôneas e monocotiledôneas não-comelinóides (composta por oligossacarídeos: XXXG, XLXG/XXLG, XXXXG). A análise por MALDI-TOF da hidrólise das frações $1 \mathrm{M}$ e $4 \mathrm{M}$ de colmo de cana-de-açúcar com endo- $\beta$-xilanase revelou a existência de xilanos lineares (série homóloga de xilanos) em conjunto com um grupo de xilanos ramificados com arabinose de forma regular, com motivos arabinosilados com até 6 xiloses na cadeia principal. As hidrólises com endo- $\beta$ xilanase e liquenase em conjunto revelaram que o arabinoxilano e o $\beta$-glucano, juntos, perfazem cerca de $40 \%$ da parede celular de cana-de-açúcar, e não interferem na hidrólise uma da outra, permitindo o uso concomitante das enzimas em processos industriais. Além disso, especula-se que as arabinoses do arabinoxilano interagem, possivelmente, através de ligações por compostos fenólicos, prevenindo a ação enzimática. $O$ presente trabalho começa a desvendar a estrutura fina das principais hemiceluloses da parede celular de colmo de cana-de-açúcar e aponta para a necessidade de experimentos que permitam compreensão de outros níveis de complexidade da parede celular, como por exemplo, as ramificações com agliconas e interações entre os polissacarídeos.

Palavras Chave: Arabinoxilano, Xiloglucano, Hemiceluloses, Parede Celular, Cana-deaçúcar, Etanol Celulósico. 


\section{Abstract}

Brazil is the second-generation ethanol producer in the World, obtaining it from sugarcane soluble sugar from culms. The second generation ethanol consists of using the energy present in the covalent linkages of the cell wall carbohydrates (cellulose, hemicelluloses and pectin) from culms and leaves (both considered nowadays as litter). This is considered as a great opportunity to increase ethanol production up to 3 times the current figures. The knowledge about sugarcane polysaccharide structure is crucial for the development of the second-generation ethanol technology. This work, aimed at the isolation and structural studies of the hemicellulosic components of the sugarcane cell walls. To achieve this, AIR (Alcohol Insoluble Residue) from culms and leaves (SP 803280 variety) were digested with endo- $\beta$-xylanase, lichenase and cellulase (in different sequences, or with isolated or combined enzymes) to help determining the fine structures of the polysaccharides. The AIR from culm was fractionated with increasing alkali concentrations $(\mathrm{NaOH} 0,1 \mathrm{M}, 1 \mathrm{M}$ and $4 \mathrm{M})$ to purify the different hemicelluloses. Only the $1 \mathrm{M}$ and $4 \mathrm{M}$ fractions were analyzed, after digestions with endo- $\beta$-xylanase, followed by HPAEC-PAD (High Performance Anionic Exchange Chromatography with Pulsed Amperometric Detection) and MALDI-TOF Mass Spectrometry analyses. Also, the oligosaccharides obtained by the endo- $\beta$-xylanase digestion were isolated by preparative TLC (Thin Layer Chromatography), re-digested with $\alpha$-arabinofuranosidases and finally analyzed by PACE (Polyacrylamide Carbohydrate Electrophoresis) in order to clarify the fine structure of the arabinoxylan from sugarcane culm. The same fractionated material was digested by an endo- $\beta$-glucanase to clarify the xyloglucan structure. The results showed that in the $4 \mathrm{M}$ fraction, a small concentration of xyloglucan can be found (ca. $3 \%$ of the total hemicelluloses), and this polysaccharide has the typical grass structure: XG, XXG, XXGG and $X X G G G / X L G G$. Other oligosaccharides, typical from eudicotyledons were also found: the XXXG, XLXG/XXLG and XXXXG. The MALDI-TOF and PACE analyses performed after digestion with endo- $\beta$-xylanase and $\alpha$ arabinofuranosidases, revealed the presence of linear xylan oligosaccharides (from 2 to 14) and also fragments with arabinose substitutions. The digestions with endo- $\beta$-xylanase and lichenase at the same time, revealed that the arabinoxylan and $\beta$-glucans, are $40 \%$ of all the sugarcane cell wall mass, and one enzyme does not interfere in the activity of the other. The present work starts to clarify the fine structure of the sugarcane culm (and leaves) major hemicelluloses, and also suggest that experiments aiming the understanding of the cell wall complexity are important steps to help developing efficient cellulosic ethanol technologies to obtain second generation ethanol from sugarcane biomass.

Key words: Arabinoxylan, Xyloglucan, Hemicelluloses, Cell Wall, Sugarcane, Cellulosic Ethanol. 


\section{Introdução}

\section{Cana-de-açúcar: do Bioetanol de sacarose à quarta geração.}

No contexto tecnológico e socioeconômico atual, o etanol, produto da fermentação dos açúcares solúveis de cana-de-açúcar (caso do Brasil), é cotado fortemente pelo mundo como um produto alternativo à queima de combustíveis fósseis, ou ao menos funcionaria como complemento de ações governamentais que visem a diminuição da emissão de gases do efeito estufa. Desde 1991 até hoje, em média, 14 milhões de litros de etanol foram produzidos (Fonte: UNICA e MAPA) todos os anos, com um forte viés de alta. Esses números fazem do Brasil o segundo maior produtor de etanol do mundo, atrás somente dos Estados Unidos. Dessa forma o etanol é importante não só para o ambiente, mas também para a economia do país.

A próxima fronteira para a expansão da produção de etanol no país é o etanol celulósico. A maioria da energia solar aprisionada na forma de carboidratos (principalmente) pela planta não está na forma de açúcar solúvel (entre eles a sacarose por nós fermentada), mas sim de açúcar insolúvel, ou seja, na parede celular. Portanto, o desafio é transformar a celulose, bem como as hemiceluloses e outros açúcares presentes na parede, em formas químicas acessíveis à fermentação dos microrganismos.

Para tal tarefa, foram descritas quatro fases para a produção de etanol (Buckeridge, 2008): A $1^{\text {a }}$ fase está completa e consiste no sistema de produção de etanol atual a partir da fermentação de açúcares solúveis. A $2^{\mathrm{a}}$ consistiria no etanol celulósico obtido por meio da hidrólise ácida dos polissacarídeos de parede celular. Por meio de alta pressão e meio ácido, consegue-se clivar as celulose e hemiceluloses em monossacarídeos fermentáveis por microrganismos. Este processo não teve sucesso e na maioria dos casos foi abandonado. A $3^{a}$ fase está sendo desenvolvida neste momento e envolverá o uso de enzimas produzidas por microrganismos, que promovem a desmontagem da parede celular, transformando-a em açúcares livres prontamente fermentáveis. O problema nesta fase consiste não somente em como hidrolisar a parede celular, mas também em como tornar os materiais solúveis accessíveis às enzimas. Processos como estes são chamados 
coletivamente de pré-tratamentos. Pode-se utilizar tanto processos físicos (steam explosion, hidrotérmico) como químicos (tratamentos com álcali e ácidos) e também ambos os processos acoplados (Soccol et al., 2010).

Por fim, prevê-se o etanol da $4^{a}$ fase, na qual a própria planta produziria as enzimas necessárias para a degradação de sua própria parede celular, um processo que substituiria os pré-tratamentos da fase 3 . Seria um processo de "autodestruição", onde a cana-de-açúcar sofreria um processo semelhante à maturação de um fruto. Após esse evento, a parede celular se encontraria em uma forma mais facilmente fermentável (Buckeridge, 2008).

O etanol da $4^{a}$ fase consistiria na "maturação" da cana-de-açúcar, antes de fermentá-la para, dessa forma, incrementar o rendimento de produto, por meio da fermentação de açúcares derivados da parede celular (Buckeridge, 2008).

Todas as abordagens possuem suas dificuldades, porém todas aumentariam em muito o aproveitamento da biomassa da cana-de-açúcar para a fabricação de etanol. Dessa forma, o combustível poderia ser ainda mais amplamente utilizado, promovendo avanços econômicos e sociais para o país.

$O$ desenvolvimento dos processos de etanol de segunda geração no Brasil concentram-se na fase 3 e começa a se preparar para a fase 4 . Nestas duas fases, um ponto central é conhecer como os polissacarídeos da parede celular do bagaço e da palhada da cana-de-açúcar podem ser hidrolisados por enzimas. Esta não é uma questão trivial, uma vez que a composição química dos polímeros dos diferentes tecidos de cana-de-açúcar são pouco conhecidos. O bagaço de cana-de-açúcar já vem sendo estudado neste aspecto, mas para que possamos acoplar as fases 3 e 4 será necessário compreender primeiro como são as paredes celulares dos diferentes tecidos da planta que geram as matérias primas usadas na indústria, ou seja, a folha, que gera a palhada e o colmo, que gera o bagaço. Este é o objetivo principal do presente trabalho.

\section{Parede Celular: Composição}

A célula vegetal possui uma composta principalmente por carboidratos poliméricos, os polissacarídeos: a parede celular. 
Polissacarídeos são polímeros de açúcares simples (chamado de monossacarídeos) quimicamente chamados de poliidroxialdeídos. Na estrutura abaixo, é dado o exemplo da sacarose, açúcar comum utilizado em alimentos, em que uma molécula de glicose (derivada de um poliidroxialdeido) é ligada a uma molécula de frutose (uma poliidroxicetona) através de uma ligação glicosídica $\beta-1,2$, ou seja, a hidroxila do carbono 1 da glicose está ligada covalentemente à hidroxila do carbono 2 da frutose.

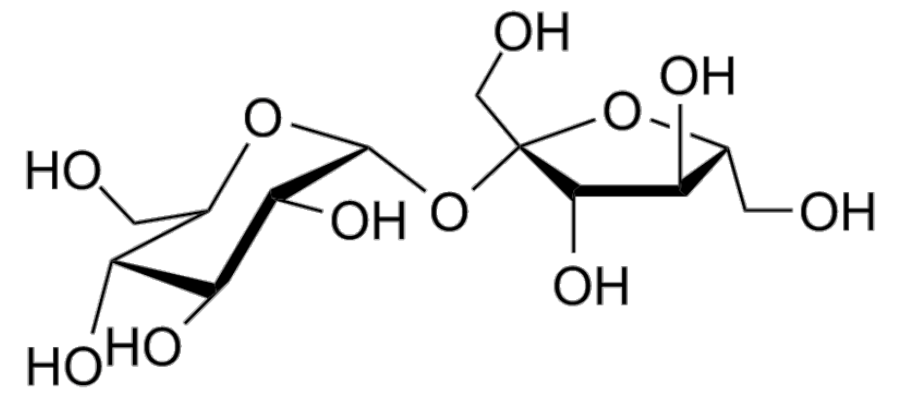

Glicose

Frutose

Dentre os carboidratos complexos podem-se encontrar dissacarídeos como a sacarose mostrada acima, bem como polímeros com várias unidades de monossacarídeos de vários tipos. Quando uma molécula possui entre 2 até 10 unidades monossacarídicas, ela é denominada oligossacarídeo. Com mais do que 10 unidades monossacarídicas denomina-se polissacarídeo.

Os polissacarídeos complexos apresentam uma cadeia principal com diversas unidades monossacarídicas ligadas entre si. O nível de complexidade varia bastante sendo os menos complexos aqueles constituídos de apenas um tipo de monossacarídeo. São exemplos o amido e a celulose, ambos feitos de glicose. A diferença entre eles é que o amido é formado por glicoses que se ligam na forma $\alpha$ enquanto na celulose as glicoses se ligam na forma $\beta$. As duas estruturas abaixo ilustram os monossacarídeos:<smiles>OC1OC(O)C2(O)C(O)C(O)C1C2O</smiles>

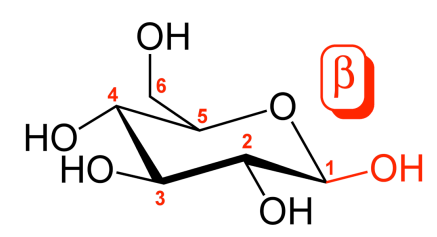

Glicoses com configurações $\alpha$ e $\beta$. 
As configurações $\alpha$ ou $\beta$ conferem propriedades completamente diferentes ao amido e à celulose, como é bem conhecido. Enquanto o amido forma grânulos em que polímeros são organizados e podem ser facilmente atacados por enzimas (amilases), a celulose consiste de longas cadeias de glicose com ligações $\beta-1,4$ (Carbono 1 de uma glicose ligado ao Carbono 4 da próxima) que interagem entre si formando microfibrilas, estruturas que são refratárias ao ataque de enzimas. A existência ou não de água na estrutura interna dos grânulos de amido e nas microfibrilas de celulose é um elemento crucial que determina se o polímero será ou não atacado por enzimas. Assim, fica claro que no caso da hidrólise da parede celular, que consiste num compósito de polímero de carboidratos e compostos fenólicos interligados de forma extremamente complexa, a capacidade de hidratação de cada polímero será fundamental.

As paredes celulares dos vegetais atingiram, durante a evolução, níveis extremamente complexos tanto em seus polissacarídeos, como na forma em que estes interagem entre si.

As hemiceluloses derivam principalmente da celulose. Mas esta classe de polímeros pode ter outros monossacarídeos na cadeia principal, como a manose e a xilose. Nestes dois casos, as ligações formadas também são do tipo $\beta-1,4$, o que confere às moléculas (como é o caso da celulose, mas não do amido) uma conformação linear. Nas hemiceluloses, as cadeias principais do polímero $\beta-1,3$ ligado podem apresentar diversos tipos de ramificações, gerando níveis muito altos de complexidade. No caso das hemiceluloses, os monossacarídeos das cadeias principais predominam em relação aos das ramificações. As ramificações das hemiceluloses não são ao acaso, já tendo sido demonstrado que há uma certa organização em alguns casos. Já se sabe há vários anos que os xiloglucanos são polímeros de glucose $\beta-1,4$ ao qual unidades de xilose se ligam periodicamente (Kooiman, 1960). Mais recentemente, Tiné et al. (2006) demostraram que os xiloglucanos de reserva de sementes apresentam um nível acima de organização, combinando blocos de oligossacarídeos de forma a produzir uma molécula com características especiais, as quais determinam o grau de interação com a celulose e a digestibilidade por enzimas hidrolíticas (Tiné et al., 2003). Este nível de 
organização é denominado estrutura fina dos polissacarídeos, sendo esta característica uma espécie de "ajuste fino" das funções de um polissacarídeo.

Todos os polissacarídeos da parede celular possuem características dadas por suas estruturas finas, as quais dependem do grau e da distribuição das ramificações com um ou mais monossacarídeos e também com outros compostos como radicais metil, acetil e compostos fenólicos de vários tipos.

A parede celular possui diversas funções no sistema da planta, variando desde conferir resistência mecânica ao tecido no qual as células estão presentes, até criar um continuum por toda a planta, por onde substâncias e água podem se deslocar (Carpita \& MacCann, 2000 in Buchanan).

Os modelos atuais de parede celular (Buckeridge et al., 2008), propõem que esta seja composta por três domínios independentes, mas que interagem entre si: a celulose e hemiceluloses (domínio fundamental), pectinas (domínio péctico), proteínas e proteínas estruturais (domínio protéico).

As paredes celulares da maioria das eudicotiledôneas e monocotiledôneas não-comelinóides possuem aproximadamente a mesma proporção de celulose e hemiceluloses, sendo estas últimas representadas por xiloglucanos. Já nas monocotiledôneas comelinóides, a hemicelulose encontrada em maior quantidade é o glucoarabinoxilano. A primeira denominase parede de tipo I e a segunda parede de tipo II (Carpita \& Gibeaut, 1993). Recentemente, foi descoberto em pteridófitas um novo tipo de parede, denominado tipo III, que possui como principal hemicelulose o manano (Silva et al., 2011)

Como introduzido acima, as hemiceluloses fazem parte da estrutura da parede celular nos vegetais, interagindo com a celulose através de pontes de hidrogênio ou formando ligações covalentes com outros polímeros (Corgrove, 1999; Carpita, 1996; Carpita \& MacCann, 2000, Buckeridge et al., 2008). As hemiceluloses possuem funções variadas, dentre elas funcionando como mecanismo de defesa, reserva de carbono, sustentação e transporte de nutrientes e água nas plantas (Buckeridge et al., 2008, Buckeridge et al., 2000).

A Figura 1 mostra um esquema representando essa interação, onde as microfibrilas de celulose são vistas interagindo com as hemiceluloses. Esta interação possui consequências interessantes, entre elas 0 fato da hemicelulose ser um importante elemento de conexão entre as microfibras de 
celulose constituintes da parede (Lima \& Buckeridge, 2001b; Lima et al., 2003; Lima et al., 2004).

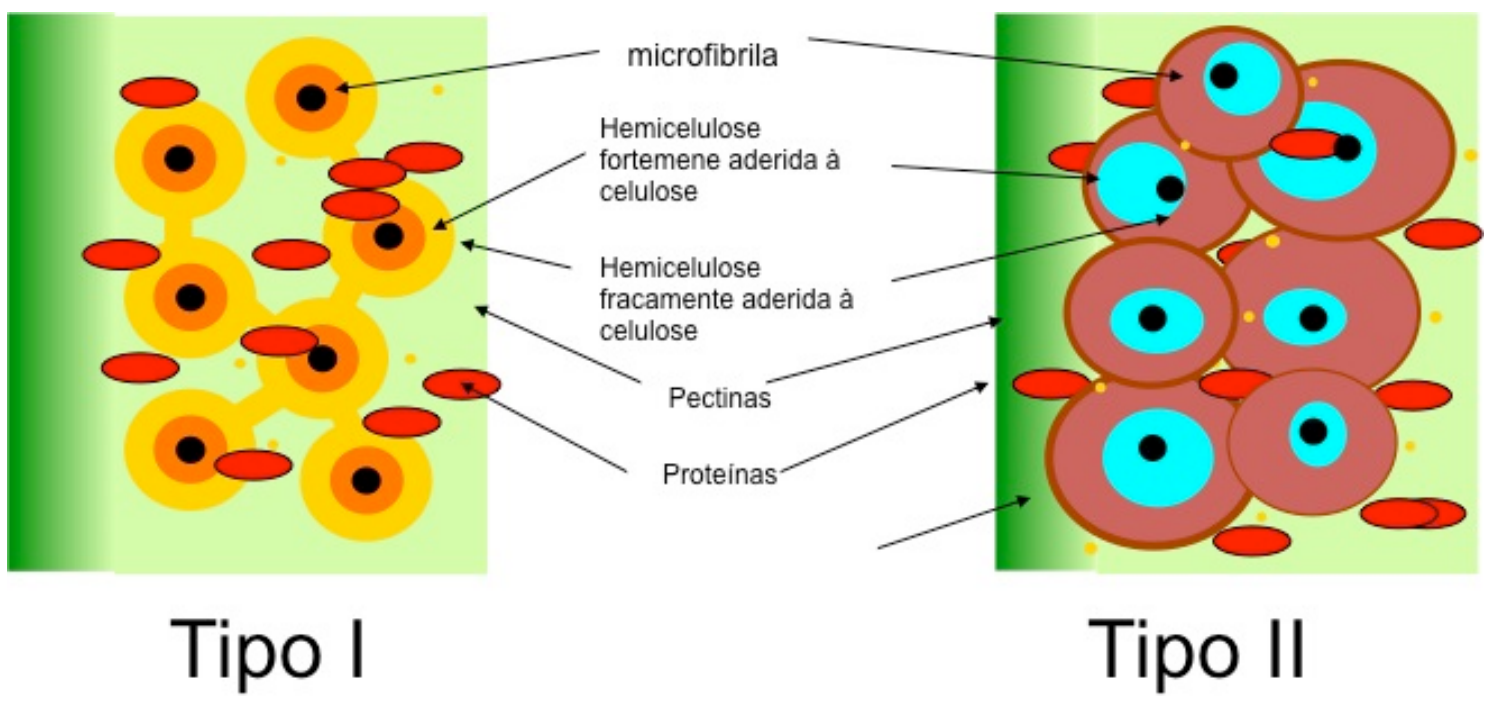

Figura 1 - Arquitetura das paredes celulares dos tipos I e II segundo as ideias de Nick Carpita e David Gibeaut em 1993. Na parede do tipo I, o domínio celulose-hemicelulose é composto por xiloglucanos com diferentes tipos de ramificações que the conferem diferentes níveis de adesão às microfibrilas (tons de laranja). A proporção entre celulose, hemicelulose e pectinas é equilibrada. Na parede do tipo II, a principal hemicelulose é o arabinoxilano (azul). Acredita-se que quando ele é sintetizado as ramificações com arabinose são retiradas quando na parede celular. O polímero menos ramificado adere fortemente às microfibrilas (azul claro), enquanto o mais ramificado adere fracamente (azul escuro). Diferentemente dos xiloglucanos, os arabinoxilanos parecem se ligar entre si por compostos fenólicos, que são mais abundantes nas paredes celulares do tipo II. Nas paredes do tipo II, a proporção de pectina é menor do que celulose e hemicelulose. (Fonte: adaptado de Buckeridge et al., 2008).

\section{Xiloglucanos}

Dentre as hemiceluloses, a mais abundante em eudicotiledôneas e monocotiledôneas não-comelinóides é o xiloglucano (Hayashi et al., 2010). Esse polissacarídeo, presente em todos os vegetais terrestres, (Fry et al., 2008) é composto por uma cadeia principal de glicoses (ligação $\beta-1,4$ ) e ramificações de xiloses $(\alpha-1,6)$, como exemplificado na figura 2 . Estas ramificações, por sua vez, podem apresentar galactoses $(\beta-1,2)$ e estas ainda apresentarem ainda outras ramificações com fucoses com ligações $(\beta-1,2)$.

Os estudos sobre a estrurura fina dos xiloglucanos mostrou que os polímeros oriundos de tecidos de eudicotiledôneas e monocotiledôneas não- 
comelinódes possuem uma distribuição de ramificações que resultam em unidades oligossacarídicas específicas quando os polímeros são tratados com endo- $\beta$-glucanases. A ação desta enzima gera quatro unidades de oligossacarídeso que são considerados os blocos constitutivos formadores do xiloglucano: o XXXG, XLXG, XXLG e XLLG (Buckeridge et al., 1992). Além destes, há vários outros oligossacarídeos, inclusive uma família completa de oligossacarídeos gerados a partir do xiloglucano de reserva de jatobá (Hymenaea courbaril), o XXXXG (Tiné et al., 2006). A chava para a nomenclatura desses oligossacarídeos é a seguinte: $\mathbf{G}$, significa que naquela posição há uma glicose não ramificada na cadeia principal. $\mathbf{X}$, significa que a glicose da cadeia principal possui uma ramificação de xilose. $\mathbf{L}$ indica a presença de uma galactose ligada à xilose que se ramifica a partir da cadeia principal de glicose (Figura 2).

Em geral, autores têm atribuído um papel fundamental ao xiloglucano e às expansinas (Li \& McQueen-Mason, 2003) no processo de expansão da parede celular (Corgrove, 1999; Carpita, 1996). Cosgrove (1999) levantou a hipótese que esta hemicelulose seria responsável pela expansão celular, através da ação da enzima xiloglucano-endo-transglicosilase-hidrolase (XTH), cuja ação permite acrescentar fragmentos de xiloglucano a uma cadeia principal de um xiloglucano existente. Este processo aumenta o comprimento da cadeia polissacarídica, possibilitando o distanciamento entre as microfibrilas de celulose, permitindo a entrada de água e, consequente, expansão celular. A expansão seria então seguida pela deposição de novas microfibrilas de celulose (Buckeridge et al., 2008).

Em monocotiledôneas comelinóides, da qual faz parte a cana-de-açúcar, o xiloglucano não representa a hemicelulose mais abundante na parede celular (Carpita, 1996; Hsieh, et al., 2010), sendo o arabinoxilano e o $\beta$-glucano os polissacarídeos encontrados em maiores proporções (Gibeaut \& Capita, 1993).

Além da proporção baixa de xiloglucano, (entre 2-5\% da massa total segundo Hsieh et al., 2010), sua estrutura em gramíneas é diferente, com unidades oligossacarídicas sendo majoritariamente três: XXGG, XXGGG e XXGGGG (Hsieh et al., 2010). 
A

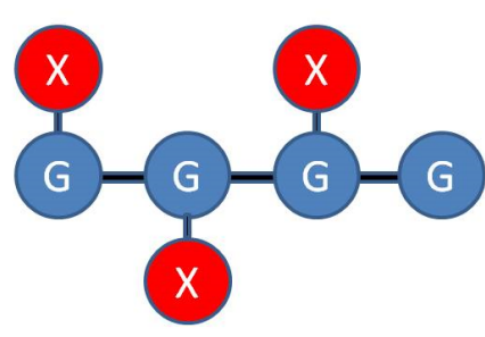

C

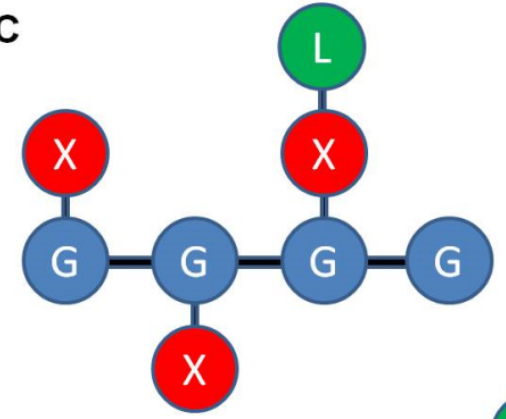

D
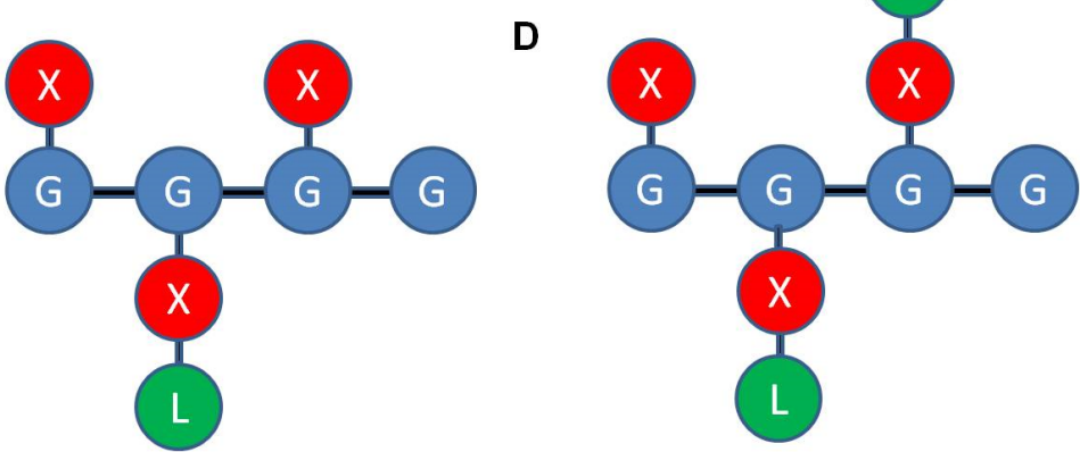

$x$

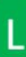

Figura 2 - Oligossacarídeos típicos obtidos através de hidrólise enzimática de xiloglucanos com celulase. Cadeia de glucoses (esferas azuis), com ramificações com xiloses (esferas vermelhas) e estas com galactoses terminais (esferas verdes). A nomenclatura do oligossacarídeo sempre se dá pelo último sacarídeo em cada subunidade, ou seja, (A) XXXG, (B) XLXG, (C) XXLG e por fim (D) XLLG, respectivamente (Fry et al., 1993).

\section{B-glucano}

O $\beta$-glucano consiste em polissacarídeos de glicose, ligadas entre si por ligações $\beta-1,4$, e com interrupções de ligações $\beta-1,3$ (figura 3 ), ou seja, é um polissacarídeo de ligação mista e sem nenhuma ramificação. Este polissacarídeo representa entre 10 e 15\% das paredes celulares de cana-deaçúcar (Amanda P. de Souza e Marcos Buckeridge, manuscrito em preparação), sendo este polímero encontrado principalmente nas gramíneas (Carpita, 1996).

A estrutura definida por Woodward e colaboradores em 1985, pautou-se no descobrimento da enzima liquenase, uma endoglucanase de Bacillus subtilis, a qual hidrolisa apenas ligações $\beta-1,4$ precedidas de uma ligação $\beta-1,3$ (Parrish, et al., 1960). Em outras palavras, os polissacarídeos de $\beta$-glucano, digeridos com liquenase, darão origem a oligossacarídeos com 3, 4 ou mais 
resíduos de glucose ligados $\beta-1,4$, intercalados com uma glucose ligada $\beta-1,3$ em sua extremidade redutora. Note, que a relação entre tri e tetrassacarídeos dita a quantidade de interrupções $\beta-1,3$ presentes na molécula.

Dessa forma, quanto menor a relação tri/tetra menor a presença de interrupções e mais parecido com a celulose é o polissacarídeo. Esta característica dita também a solubilidade do polissacarídeo, sendo que quanto maior a proporção de $\beta-1,3$, maior a solubilidade (Buckeridge et al., 2004). Apesar das proporções entre tri e tetrassacarídeos ser bem conhecida entre diferentes espécies e girar em torno de 2:1 na maioria dos casos, não se conhece como estes blocos estão arranjados no polímero, ou seja, o nível de complexidade acima de sua estrutura fina.

G

\section{G}

\section{G}

\section{G}

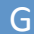

\section{G}

G

G

G

G

Figura 3 - Esquema exemplificando a ligação entre os resíduos de glucose em uma molécula de $\beta$ glucano. Ligações lineares $\beta-1 \rightarrow 4$ são interrompidas por ligações $\beta-1 \rightarrow 3$, as quais mudam o sentido da molécula, como exemplificado após o quinto resíduo acima (ligações $\beta-1 \rightarrow 3$ indicadas por setas).

\section{Arabinoxilano}

O arabinoxilano é um polissacarídeo composto por uma cadeia principal de xilose, ligados em $\beta-1,4$, com substituições de arabinose com ligação $\alpha-1,2$ e/ou $\alpha-1,3$ (Figura 4). Este polissacarídeo representa entre $25 \%$ a $33 \%$ da parede celular de cana-de-açúcar (Amanda P. de Souza e Marcos Buckeridge, manuscrito em preparação). Já o glucoarabinoxilano, possui além das substituições acima referidas, ligações $\alpha-1,6$ com ácido glucurônico. Este polissacarídeo ainda não foi observado em cana-de-açúcar (Silva, 2005), como será reforçado no presente trabalho, porém sua presença não é descartada. 
Alguns tipos de ramificações, além de monossacarídeos, podem estar ligadas aos arabinoxilanos, entre elas radicais metila, ácido ferúlico e ácido paracumárico (Buanafina, 2009). Na Figura 4 são mostrados alguns exemplos.

Acetilação pode ocorrer diretamente na cadeia principal, enquanto os compostos fenólicos se ligam à arabinose. Pode haver nas ramificações com ácido ferúlico, a formação de diferulatos, que ligam duas cadeias de arabinoxilanos covalentemente. Os ácidos ferúlicos são considerados como os iniciadores da formação da lignina na parede celular.

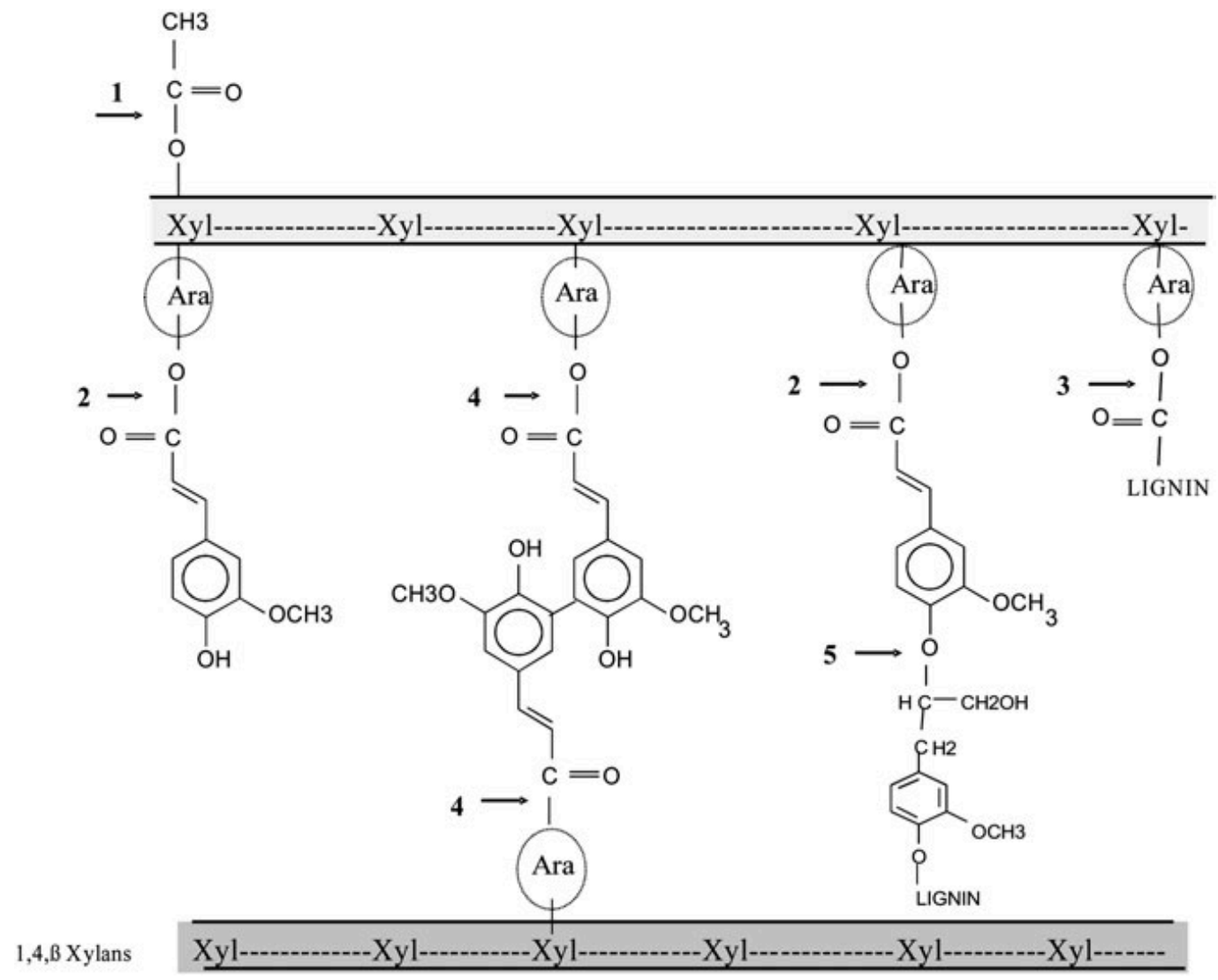

Figura 4 - Principais ramificações dos arabinoxilanos de paredes celulares de gramíneas. As cadeias de xilano são representadas pelas linhas pontilhada e os resíduos de arabinose (Ara) podem apresentar: grupos acetila (1), éster de ácido ferúlico ligado ao arabinoxilano (2), arabinose ligada diretamente à lignina (3) ou diferulatos formando ligações cruzadas entre polissacarídeos (4) e ésteres de ácido ferúlico ligados à lignina (5). Fonte: Buanafina (2009).

Estas características dos arabinoxilanos the conferem propriedades peculiares como polímero da parede celular. Por se apresentarem em grande proporção em paredes celulares de gramíneas, resulta que as paredes destas plantas apresentem autofluorescência. Por absorverem luz UVEstas ramificações, portanto, podem apresentar uma proteção contra a luz 
ultravioleta, uma vez que gramíneas são, via de regra, plantas que crescem a sol pleno, assim como podem funcionar como proteção contra o ataque de herbívoros.

Por decorarem a cadeia principal dos arabinoxilanos, já foi demonstrado que tanto os radicais acetila quanto os ácidos diferúlicos interferem na ação de enzimas hidrolíticas sobre o arabinoxilano (Grohmann et al., 1989, Mitchell et al., 1990 e Grabber et al., 1998, respectivamente).

A solubilidade em álcali dos arabinoxilanos, bem como sua solubilidade em solventes como água e álcool, é em grande parte determinada pelas ramificações acima citadas (Rubroeks, et al., 2000). Maiores proporções entre arabinose/xilose, ou seja, polissacarídeos mais ramificados, resultam em maiores solubilidades, e quanto menor o número de substituições menor a solubilidade. Este fenômeno decorre das interações moleculares entre as hemiceluloses de parede com as demais hemiceluloses e este complexo com a celulose.

Por outro lado, é importante salientar que o tratamento da parede celular de gramíneas com álcali leva à desacetilação do polímero (Tjeerdsma \& Militz, 2005). Como os ácidos ferúlicos estão ligados à arabinose através de um radical acila, estes também são quebrados em álcali, tornando a solubilidade do arabinoxilano dependente somente das arabinoses que ramificam o polímero. Portanto, é importante sempre considerar os tratamentos prévios efetuados quando se consideram as propriedades de arabinoxilanos preparados a partir de parede celular de gramíneas.

Como no caso dos xiloglucanos e $\beta$-glucanos, os arabinoxilanos apresentam também uma estrutura fina que pode ser acessada através do uso de endo- $\beta$-xilanases e subsequentes análises por técnicas como cromatografia de troca aniônica de alta performance (HPAEC), espectrometria de massas MALDI-TOF (p.ex. Ryan et al., 2003, Van Gool et al., 2011); e considerando os tipos de ramificação de não-carboidratos, pode-se dizer que a estrutura fina dos arabinoxilanos é ainda mais complexa do que as das demais hemiceluloses.

Por outro lado, as ramificações com acetila e compostos fenólicos são dependentes das posições das arabinoses, o que faz com que ao se conhecer esta distribuição se possa aprofundar e compreender como os arabinoxilanos 
interagem na parede celular. Apesar da importância que a estrutura fina parece ter para a determinação da digestibilidade dos polissacarídeos de parede celular, como os arabinoxilanos, a maioria dos trabalhos em que esta foi abordada, o foco não tem sido a estrutura, mas sim a aplicação do material para utilização de alguma nova enzima ou de algum processo industrial.

\section{Implicações no etanol celulósico}

As propriedades de cada polissacarídeo, suas proporções relativas e as diversas inter-relações entre eles, e ainda deste complexo com a celulose, e a lignina, salientam o alto nível de complexidade da tarefa de degradar a parede celular de cana-de-açúcar com a eficiência necessária para a obtenção comercial de açúcares fermentáveis e do etanol de segunda geração.

A celulose, considerada o "graal" do etanol celulósico, está envolta por hemiceluloses que interagem com todo o complexo à sua volta, portanto para acessá-la, o complexo deve ser desfeito, seja por força física e química (prétratamentos com ácidos, álcalis, vapor, etc.) ou utilizando-se as ferramentas bioquímicas, mais específicas para cada tipo de ligação na parede. Dessa forma, conhecer a composição e a estrutura fina dos elementos principais presente na parede é crítico para o uso da estratégia enzimática (Buckeridge et al., 2010).

A estratégia enzimática, quando comparada à estratégia físico-química de degradação da biomassa, apresenta como vantagem os menores custos de implantação (custo reduzido dos fermentadores), bem como temperatura e pH de operação mais amenos (Johnson et al., 2008), além de subprodutos do processo menos impactantes dada a menor utilização de ácidos e bases.

Sendo assim, a maquinaria enzimática em desenvolvimento pelos grandes centros de pesquisa no assunto pelo mundo, representa uma grande expectativa na viabilização do etanol celulósico em longo prazo (Buckeridge et al., 2010). Para tanto, as propriedades físicas e químicas das paredes celulares de uma das principais fontes de biomassa para a produção de etanol no mundo, a cana-de-açúcar, precisam ser compreendidas com o maior nível de profundidade possível. Este foi o objetivo do presente trabalho. 


\section{Objetivo}

Determinar a estrutura fina do arabinoxilano e do xiloglucano da parede celular de cana-de-açúcar (SP80 3280) e ampliar o conhecimento em composição, e contribuir com o conhecimento em estrutura fina desta planta. 


\section{Material e Métodos}

\section{Material Vegetal}

A cana-de-açúcar variedade SP80-3280 utilizada na realização dos experimentos foi gentilmente cedida pela MSc Adriana Grandis (Sítio Vitória, localizado no município de Piracicaba-SP).

Este material foi processado no dia seguinte de sua coleta, para uso do colmo e folha como fonte de material para estudos de estrutura de parede celular de cana-de-açúcar.

\section{Estrutura fina das principais hemiceluloses da parede celular de cana-de- açúcar}

Com a finalidade de estudar a estrutura fina das hemiceluloses da parede celular de cana-de-açúcar, primeiramente, procedeu-se à extração da parede celular de ambos os materiais, colmo e folha de cana-de-açúcar adulta. As paredes foram submetidas a hidrólise enzimática com enzimas específicas para as três principais hemiceluloses de gramíneas, endo- $\beta$-xilanase (arabinoxilanos), liquenase ( $\beta$-glucanos) e endo- $\beta$-glucanase (xiloglucanos).

Em segunda análise, visando determinar a presença de xiloglucano e caracterizar os arabinoxilanos presentes em parede celular de colmo de canade-açúcar, procedeu-se com um fracionamento químico da parede de colmo de cana-de-açúcar, seguido de análises da estrutura fina utilizando as enzimas Xilanase de Thermomyces lanuginosus (Sigma®) e Celulase de Trichoderma longibrachiatum (Megazyme $\left.{ }^{\circledR}\right)$. Os oligossacarídeos provenientes da digestão foram analisados por cromatografia aniônica de alta performance com detecção amperométrica pulsada (High Performance Anion Exchange Chromatography with Pulsed Amperometric Detection - HPAEC-PAD) e por cromatografia em camada delgada (Thin Layer Chromatography - TLC). As bandas isoladas foram analisadas por eletroforese de carboidratos em géis de poliacrilamida (Polyacrylamide Carbohydrate Electrophoresis - PACE). Algumas misturas de oligossacarídeos foram analisadas por espectrometria de massas MALDI-TOF. 


\section{Extração da parede celular de colmo e folha de cana-de-açúcar}

Colmos de cana-de-açúcar foram lavados, descascados e em seguida prensados em uma moenda para a extração mecânica do caldo, rico em açúcares solúveis. $\mathrm{O}$ bagaço resultante deste processo foi congelado, seco em liofilizador e processado em moinho de facas. Esse material foi submetido a uma segunda moagem em moinho de bola para a pulverização do material.

As folhas foram lavadas, congeladas, secas em liofilizador e moídas diretamente em moinho de bola.

Do material pulverizado, tanto de colmo como de folha, resultante da moagem, foram extraídos, exaustivamente, os açúcares solúveis utilizando etanol $80 \%$ a $80^{\circ} \mathrm{C}$ sob agitação (Silva, 2005), seguido de secagem à $60^{\circ} \mathrm{C}$ em estufa. Este material resultou no resíduo insolúvel em álcool (AIR - do inglês Alcohol Insoluble Residue) formado principalmente por parede celular.

\section{Comparação da composição e estrutura da parede celular de colmo e folha de cana-de-açúcar}

A fim de comparar a composição e estrutura dos polissacarídeos presentes na parede celular de colmo e folha de cana-de-açúcar, procedeu-se com digestões enzimáticas individuais utilizando, como substrato: parede celular extraída de colmo e de folha (como descrito no item acima), e as enzimas: Lichenase de Bacilus subtillis $\left(\right.$ Megazyme ${ }^{\circledR}$ ), Xilanase de Thermomyces lanuginosus $\left(\right.$ Sigma $\left.^{\circledR}\right)$ e Celulase de Thricoderma longibrachiatum (Megazyme ${ }^{\circledR}$ ). Note que cada uma destas enzimas pode possuir contaminantes, estando todos descritos na bula dos produtos. Nos momentos em que a presença de contaminantes poderia ter influenciado nos resultados, medidas atenuantes foram apresentadas, ou os dados foram interpretados à luz da possível influência de atividades enzimáticas estranhas ou contaminantes.

A restrição no uso dessas enzimas é justificada pelo conhecimento prévio da possível composição de hemiceluloses da parede celular de cana-de- 
açúcar: arabinoxilanos (xilanase), $\beta$-glucanos (lichenase) e xiloglucano (celulase).

A digestão enzimática foi preparada a partir de uma solução de parede celular (colmo ou folha) à 1\% (peso/volume) em tampão acetato de amônio $50 \mathrm{mM}$ pH 5.0, na qual foi acrescentado o volume equivalente a concentração final de $0,5 \mathrm{U}$ de celulase, xilanase ou lichenase, obtendo-se um volume final de ensaio de $500 \mu \mathrm{L}$.

A incubação da mistura foi realizada à $30^{\circ} \mathrm{C}$ por $24 \mathrm{~h}$, com posterior fervura por 5 minutos (adaptado de Cavalari, 2009). Após a fervura, os tubos foram centrifugados à $2700 \mathrm{~g}$, por $5 \mathrm{~min}$ a temperatura ambiente e o sobrenadante coletado, seco em um concentrador de amostras (sem aquecimento) e então ressuspendido em $500 \mu \mathrm{L}$ de água deionizada para análise qualitativa dos oligossacarídeos formados pela digestão enzimática por HPAEC-PAD (High Performance Anion Exchange Chromatography with Pulsed Amperometric Detection).

Análise de oligossacarídeos por Cromatografia Aniônica de Alta Performance com detecção por Amperométrica Pulsada (HPAEC-PAD).

O método utilizado no HPAEC-PAD para análise dos oligossacarídeos foi adaptado do protocolo descrito por Tiné et al. (2003) visando a otimização na visualização destes após a digestão enzimática com as enzimas: liquenase, xilanase ou celulase, dos materiais de cana-de-açúcar (colmo ou folha).

O sistema utilizado foi um HPAEC-PAD modelo ICS-3000 da marca Dionex ${ }^{\circledR}$, utilizando uma coluna CarboPac PA-100. O eluente de base utilizado foi $\mathrm{NaOH} 88 \mathrm{mM}$ e o eluente de arraste acetato de sódio $200 \mathrm{mM}$ em $\mathrm{NaOH}$ $88 \mathrm{mM}$. Um gradiente da solução de acetato de sódio $200 \mathrm{mM}$ em NaOH $88 \mathrm{mM}$ foi aplicado à amostra visando separar os oligossacarídeos antes de sua detecção pelo detector amperométrico, este gradiente pode ser visualizado na figura 5 . 


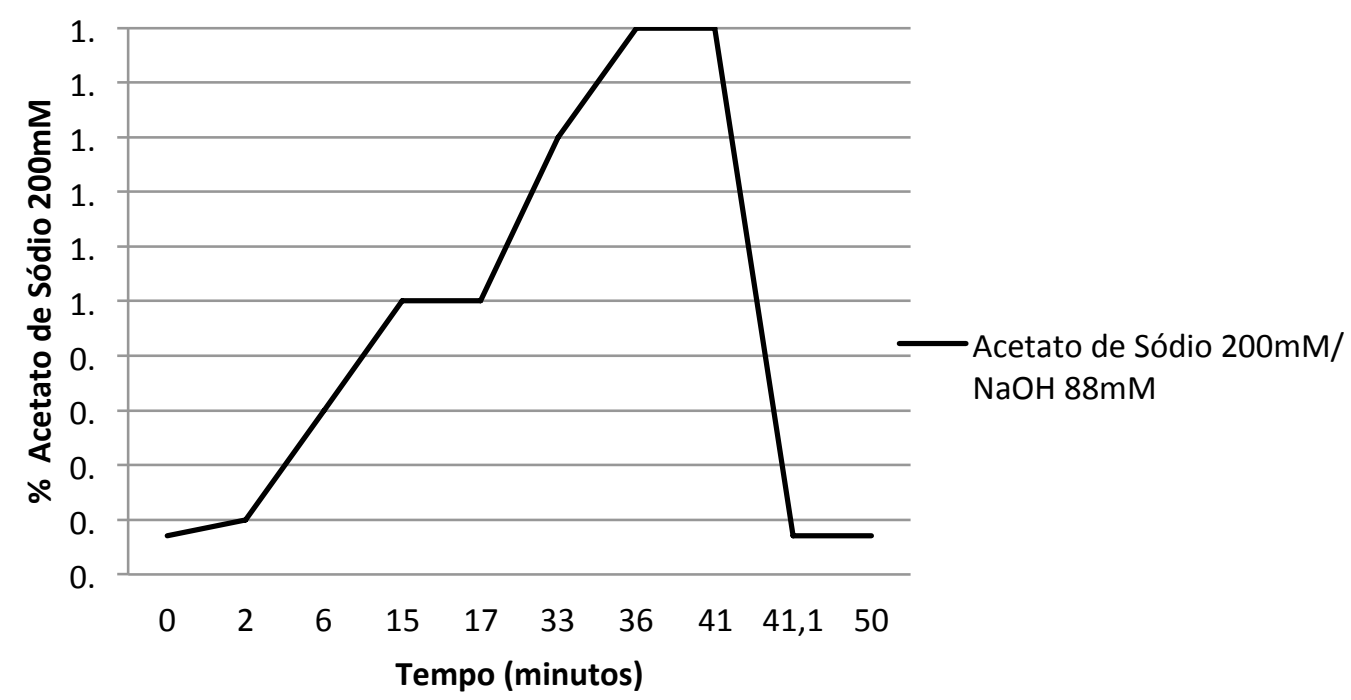

Figura 5 - Concentração de acetato de sódio ao longo de uma corrida visando a separação dos oligossacarídeos e a posterior detecção no amperômetro. Sistema HPAED-PAD, Dionex ${ }^{\circledR}$ ICS-3000, com coluna CarboPac PA-100.

\section{Fracionamento da parede celular de colmo de cana-de-açúcar e análise da estrutura fina do xiloglucano e arabinoxilano}

A metodologia de fracionamento foi desenvolvida a partir do procedimento de Gorshkova et al. (1996). Este protocolo foi modificado para garantir maior rendimento das frações de parede celular de cana-de-açúcar. $\mathrm{O}$ fracionamento foi feito a partir de $10 \mathrm{~g}$ do pulverizado de parede celular de colmo de cana-de-açúcar descrito no item Extração de parede celular de colmo e folha de cana-de-açúcar.

Este material foi submetido a mais uma extração de açúcares solúveis, onde $10 \mathrm{~g}$ do pulverizado de parede celular de cana-de-açúcar foram acrescidos de $400 \mathrm{~mL}$ de etanol comercial $80 \%$, a $80^{\circ} \mathrm{C}$ por 1 hora, sob agitação, em seguida, o material foi filtrado em membrana de nylon, sendo o precipitado (material retido no filtro) submetido a nova extração seguindo os mesmos parâmetros. No total, foram executadas 8 extrações, sendo o resíduo das extrações lavado uma última vez com álcool etílico PA $80 \%$, seguindo os mesmos parâmetros.O sobrenadante foi descartado. 
As extrações de açúcares solúveis foram feitas até o sobrenadante não apresentar níveis detectáveis de açúcar, mensurados pelo método de FenolSulfúrico (Dubois, 1956).

O precipitado resultante foi seco em estufa a $60^{\circ} \mathrm{C}$ e pesado para análise do rendimento do fracionamento (Tabela 2).

O material seco e pesado foi submetido à extração com de $400 \mathrm{~mL}$ de oxalato de amônio $0,5 \%$ e mantido sob agitação a $80^{\circ} \mathrm{C}$ por 3 horas. Em seguida, a mistura foi filtrada em membrana de nylon, sendo o sobrenadante descartado e o precipitado lavado repetidas vezes para retirada do excesso de oxalato de amônio. $\mathrm{O}$ resíduo foi seco em estufa a $60^{\circ} \mathrm{C}$.

O precipitado resultante da secagem foi submetido à extração de hemiceluloses através de lavagens com hidróxido de sódio em concentrações crescentes $(0,1 \mathrm{M} ; 1 \mathrm{M}$ e $4 \mathrm{M}$; acrescido de boroidreto de sódio $3 \mathrm{mg} / \mathrm{L})$. Primeiramente duas extrações com $\mathrm{NaOH} 0,1 \mathrm{M}$, sob agitação, em temperatura ambiente por 1 hora, em seguida, o material foi filtrado em membrana de nylon. Os sobrenadantes das duas extrações (contendo as hemiceluloses extraídas) foram reunidos e após neutralização com ácido acético glacial, dialisado contra água destilada, congelado a $-20^{\circ} \mathrm{C}$, seco em liofilizador e pesado.

O mesmo procedimento foi realizado em sequência com os precipitados, mas utilizando $\mathrm{NaOH} 1 \mathrm{M}$ e $4 \mathrm{M}$ sucessivamente.

A Tabela 2 reúne os rendimentos obtidos em cada passo do fracionamento da parede celular de cana-de-açúcar.

Os polímeros das frações $1 \mathrm{M}$ e $4 \mathrm{M}$ foram submetidos à hidrólise enzimática. Hidrólise com xilanase (Thermomyces lanuginosus Sigma ${ }^{\circledR}$ ) a $10 \mathrm{U} / \mathrm{mL}$ foi efetuada com a finalidade de aumentar as proporções de xiloglucanos nas frações, bem como impedir a atividade da endo-celulase $\left(\right.$ Megazyme $^{\circledR}$ ) sobre xilanos/arabinoxilanos do material, o que inviabilizaria a análise dos oligossacarídeos de xiloglucano por MALDI-TOF.

As digestões enzimáticas foram preparadas a partir de $150 \mathrm{mg}$ de cada fração, $1 \mathrm{M}$ e $4 \mathrm{M}$, acrescidas de tampão acetato de amônio $50 \mathrm{mM} \mathrm{pH} 5,0$, às quais foi acrescentado $10 \mathrm{U} / \mathrm{mL}$ de xilanase, obtendo-se um volume final de ensaio de $8 \mathrm{~mL}$. 
A incubação das misturas foi realizada a $37^{\circ} \mathrm{C}$ por $3 \mathrm{~h}$, com posterior fervura por 10 minutos. Após a fervura, os tubos foram centrifugados a $2700 \mathrm{~g}$, por $5 \mathrm{~min}$, a temperatura ambiente, sendo os sobrenadantes (ricos em oligossacarídeos decorrentes da digestão pela xilanase) coletados e armazenados para posterior análise em MALDI-TOF e PACE, enquanto que os resíduos sólidos (precipitados) foram lavados exaustivamente com água destilada, centrifugados a $2700 \mathrm{~g}$ por 5 minutos. Os precipitados foram congelados a $-20^{\circ} \mathrm{C}$ e secos em liofilizador para hidrólise com celulase, visando determinar a presença de xiloglucano, tanto na fração $1 \mathrm{M}$ quanto na $4 \mathrm{M}$, pela identificação de seus oligossacarídeos formadores em espectrometria de massas (MALDI-TOF).

Os resíduos (precipitados) da hidrólise das frações $1 \mathrm{M}$ e $4 \mathrm{M}$ com xilanase, após congelamento e secagem, foram ressuspendidos em $3 \mathrm{~mL}$ de tampão acetato de amônio $50 \mathrm{mM}$ pH 5.0 e à suspensão foram adicionados $5 \mathrm{U} / \mathrm{ml}$ de celulase Trichoderma longibrachiatum (Megazyme $\AA$ ). As digestões foram mantidas a $37^{\circ} \mathrm{C}$ por 16 horas, sendo interrompidas por 10 minutos em fervura. Após centrifugação a $2700 \mathrm{~g}$ por 5 minutos, os sobrenadantes foram coletados e utilizados como fonte de oligossacarídeos de xiloglucano.

Dessa forma, ao final da etapa do fracionamento enzimático obtiveramse oligossacarídeos de xilanos/arabinoxilanos das frações $1 \mathrm{M}$ e $4 \mathrm{M}$, bem como, oligossacarídeos de xiloglucano também de ambas as frações. Estas amostras serviram tanto para a realização de análises por espectrometria de massas, HPAEC, TLC e PACE. 


\section{Análise dos oligossacarídeos provenientes da digestão enzimática das frações $1 M$ e $4 M$ da parede de celular de colmo de cana-de-açúcar com xilanase e celulase por espectrometria de massas (MALDI-TOF)}

Alíquotas das misturas dos oligossacarídeos provenientes da digestão enzimática das frações $1 \mathrm{M}$ e $4 \mathrm{M}$ do fracionamento químico de colmo de canade-açúcar foram analisados em HPAEC-PAD (seguindo a metodologia descrita no item Análise de oligossacarídeos por Cromatografia Aniônica de Alta Performance com detecção por Amperométrica Pulsada (HPAEC-PAD)) antes do encaminhamento das amostras ao MALDI-TOF. Em conjunto, as duas técnicas possibilitaram a identificação dos principais oligossacarídeos da mistura.

Anteriormente à espectrometria de massas, uma alíquota de cada uma das quatro amostras (oligossacarídeos de xilano/arabinoxilano provenientes da hidrólise da fração $1 \mathrm{M}$ e $4 \mathrm{M}$ com xilanase; oligossacarídeos de xiloglucano provenientes da hidrólise da fração $1 \mathrm{M}$ e $4 \mathrm{M}$ com celulase) foi submetida à precipitação com etanol $80 \%$ gelado, visando precipitar polissacarídeos não digeridos, promovendo dessa forma uma purificação dos oligossacarídeos (Silva, 2001).

Aos sobrenadantes de cada tratamento foram acrescidos 3 volumes de etanol $80 \%$ gelado, em seguida estes foram mantidos a $-20^{\circ} \mathrm{C}$ durante a noite e em seguida centrifugados a $2700 \mathrm{~g}$ por 10 minutos. A suspensão etanólica (sobrenadante) foi coletada, seca em concentrador de amostras sem aquecimento Speed $V a c^{\circledR}$ e levadas para Universidade de Cambridge para as análises em espectrômetro de massas MALDI-TOF durante a visita àquele laboratório.

Para aplicação das amostras no espectrômetro, estas foram inicialmente ressuspendidas em água e submetidas ao seguinte protocolo: $5 \mu \mathrm{L}$ de cada amostra foi dissolvida em metanol e homogeneizada a $5 \mu \mathrm{L}$ de matriz 2,5-DHB. Um microlitro desta mistura foi depositado em uma placa de MALDI e, então, teve sua massa mensurada no equipamento MALDI-TOF segundo o procedimento descritos por Maslen et al. (2007). Tal procedimento possibilitou a inferência da composição dos oligossacarídeos naquela mistura. 
Análise oligossacarídeos provenientes da digestão enzimática das frações $1 M$ e $4 M$ da parede de celular de colmo de cana-de-açúcar com xilanase por eletroforese de carboidratos em gel de poliacrilamida (PACE).

Após a hidrólise enzimática com Xilanase de Thermomyces lanuginosus (Sigma ${ }^{\circledR}$ ) das frações $1 \mathrm{M}$ e $4 \mathrm{M}$, alíquotas dos sobrenadantes contendo os oligossacarídeos resultantes de cada digestão foram submetidas à Cromatografia de Camada Delgada (TLC) preparativa.

A etapa de TLC foi realizada com o intuito de isolar cada oligossacarídeo formado de ambas as digestões, obtendo-se uma material com grau de purificação parcial. Isto foi feito através da raspagem da placa de sílica e isolamento de cada banda (oligossacarídeo), permitindo a análise de composição dos xilanos/arabinoxilanos separadamente, diminuindo a contaminação entre os oligossacarídeos.

Para tanto, o sobrenadante de cada digestão (frações $1 \mathrm{M}$ e $4 \mathrm{M}$ com xilanase) foi aplicado a $1 \mathrm{~cm}$ da base de uma placa de sílica $\left(\right.$ Merck $\left.^{\circledR}\right)$ de $20 \times 20 \mathrm{~cm}$ e submetido à 3 corridas utilizando como eluente 1 -propanol-metanolágua; na proporção de 2:1:1.

Ao final das três corridas, um centímetro de cada borda e do centro de cada placa foram recortados e revelados com solução etanólica contendo $5 \%$ de ácido sulfúrico, seguido de incubação em estufa a $100^{\circ} \mathrm{C}$. Este procedimento visou orientar a localização de cada banda, referente a cada oligossacarídeo formado, e permitir a raspagem da sílica para separação de cada banda.

Após raspagem da placa de TLC preparativa e separação, em microtubos de $1,5 \mathrm{~mL}$, de cada banda, foi feita a eluição em água deionizada dos oligossacarídeos retidos na sílica, realizada através de 3 lavagens com água deionizada, seguida de centrifugação a $10.000 \mathrm{~g}$ por 30 minutos a $4^{\circ} \mathrm{C}$.

Cada uma das bandas raspadas foi analisada em HPAEC-PAD como descrito acima. As bandas foram secas em liofilizador para posterior ensaio em PACE.

As bandas purificadas e identificadas como $1 ; 3 ; 4$, de ambas as frações - $1 \mathrm{M}$ e $4 \mathrm{M}$ - digeridas com xilanase, foram submetidas a duas digestões com 
arabinofuranosidases, uma pertencente da família 51 (GH51) e a outra pertencente da família 62 (GH62).

Essas digestões objetivaram visualizar a mudança de peso molecular de bandas em géis PACE que porventura possuíssem ramificações com arabinoses. Dessa forma, as bandas 1; 3; 4 das digestões das frações $1 \mathrm{M}$ e $4 \mathrm{M}$ foram ressuspendidas em tampão acetato de sódio 50mM pH5.0, em seguida, uma alíquota de $200 \mu \mathrm{L}$ de cada banda foi acrescido de $1 \mathrm{U}$ de cada uma das enzimas separadamente. As hidrólises foram mantidas a $30^{\circ} \mathrm{C}$ durante a noite.

As hidrólises foram interrompidas por 5 minutos de fervura e, em seguida, centrifugadas a $2700 \mathrm{~g}$ por 5 minutos, sendo os sobrenadantes separados e derivatizados, como descrito abaixo, para posterior análise em PACE.

A metodologia empregada no PACE foi a mesma para os oligossacarídeos purificados das digestões das frações $1 \mathrm{M}$ e $4 \mathrm{M}$ com xilanase, a mistura de oligossacarídeos das digestões das frações $1 \mathrm{M}$ e $4 \mathrm{M}$ com xilanase, a mistura de oligossacarídeos das digestões com arabinofuranosidases das bandas purificadas 1, 3 e 4 da digestão das frações $1 \mathrm{M}$ e $4 \mathrm{M}$ com xilanase e o padrão de oligossacarídeos de xilanos (misturas de oligossacarídeos de xilano com 1, 2, 3, 4, 5 e 6 resíduos de xilose).

Os oligossacarídeos (purificados, mistura - digestão com xilanase ou arabinofuranosidases e padrão) foram derivatizados com ANTS (ácido 1,3,6trisulfônico-8-aminonaftaleno), seguindo o protocolo descrito abaixo, para que os oligossacarídeos pudessem ser visualizados após a separação em géis de poliacrilamida.

A cada amostra $(10 \mu \mathrm{L}$ de suspensão de cada um dos polissacarídeos purificados e das misturas de oligossacarídeos, ambos, provenientes das digestões de xilanase; do padrão e controle da enzima Xilanase Sigma ${ }^{\circledR}$ ) adicionou-se $10 \mu \mathrm{L}$ do tampão de DMSO $(30 \mu \mathrm{L}$ ácido acético, $170 \mu \mathrm{L}$ de água destilada e 200 $\mu \mathrm{L}$ de DMSO), $5 \mu \mathrm{L}$ de ANTS 0.2M em água:ácido acético (17:3) e $5 \mu \mathrm{L}$ de uma solução aquosa de $\mathrm{NaBH}_{3} \mathrm{CN}$ (Cianoboroidreto de sódio), sendo a mistura mantida sob agitação durante a noite a $37^{\circ} \mathrm{C}$.

Em seguida, os tubos foram deixados abertos por 30 minutos em uma capela para evaporação do cianeto e, em seguida, seco em concentrador de 
amostras Speed $\operatorname{Vac}^{\circledR}$ a $40^{\circ} \mathrm{C}$. Os materiais secos foram ressuspendidos em uréia $6 \mathrm{M}$ e aplicados em gel de poliacrilamida.

Foram aplicados $4 \mu \mathrm{L}$ de cada amostra no gel de poliacrilamida e a corrida foi feita a $200 \mathrm{~V}$ por 30 minutos. Para finalizar a separação, a placa foi mantida a $1000 \mathrm{~V}$ por 2 horas.

A revelação do gel foi realizada por luz UV em transiluminador com registro fotográfico da imagem.

\section{Digestão enzimática sequencial utilizando liquenase e xilanase em parede celular de colmo de cana-de-açúcar.}

A fim de compreender as limitações impostas à hidrólise enzimática de parede celular de cana-de-açúcar devido à interação entre os polissacarídeos na parede celular nativa foi preparado, como substrato, o resíduo insolúvel em álcool (AIR - do inglês, Alcohol Insoluble Residue), que consiste principalmente nas paredes celulares de colmo de cana-de-açúcar, após extração com etanol $80 \%$, como descrito anteriormente. Considerando que as principais hemiceluloses, em termos quantitativos, são os arabinoxilanos e o $\beta$-glucano, foram utilizadas para hidrólise as enzimas liquenase de Bacilus subtillis (Megazyme ${ }^{\circledR}$ ), Xilanase de Thermomyces lanuginosus (Sigma®). A celulase de Trichoderma longibatraqueum (Megazyme $\AA$ ) não foi utilizada neste experimento por dois motivos: 1) o xiloglucano se apresentou em concentrações muito baixas e 2) a celulase utilizada neste trabalho apresentou hidrólise sobre os arabinoxilanos, ou devido à contaminação ou devido à atividade secundária desta sobre os xilanos/arabinoxilanos.

A digestão sequencial foi realizada em amostras de parede celular de colmo de cana-de-açúcar (AIR), seguindo os parâmetros de digestão descritos no item anterior: solução de parede celular a $1 \%(p / v)$ em acetato de amônio $50 \mathrm{mM}$ pH5,0, acrescida de volume correspondente de enzima para concentração final de $0,5 \mathrm{U}$, totalizando $500 \mu \mathrm{L}$ de reação. A incubação se deu a $30^{\circ} \mathrm{C}$, por $24 \mathrm{~h}$, seguida de fervura por 5 minutos e centrifugação a $2700 \mathrm{~g}$ por 5 minutos para recuperação e armazenamento do sobrenadante, bem como a utilização do precipitado para o segundo ensaio, após sucessivos ciclos de lavagem com água, seguidos de centrifugação. 
No tempo zero do experimento, uma das enzimas foi adicionada (xilanase ou liquenase). Após o ciclo de digestão de 24h, a reação foi parada com fervura de 5 minutos e, como descrito anteriormente, teve o sobrenadante coletado. O precipitado restante foi ressuspendido no mesmo volume inicial de tampão acetato de amônio $50 \mathrm{mM}$ pH5,0 e uma nova enzima foi adicionada, porém sempre a enzima diferente da anterior (liquenase ou xilanase, dependendo da primeira digestão). A reação com a nova enzima seguiu por mais $24 \mathrm{~h}$, e o processo de inativação e preparação da amostra foi repetido. Vale lembrar que antes da adição da nova enzima, o precipitado era lavado com água.

Foram dois tratamentos seguindo esse protocolo, um começando o primeiro ciclo de digestão com xilanase e terminando com liquenase e, um segundo tratamento, começando com liquenase e terminando com xilanase (Tabela 1).

Além disso, quatro controles foram estabelecidos:

a) Os dois ciclos de digestão com a mesma enzima. Este controle é duplo, pois foi realizado tanto para a liquenase como para xilanase (visou determinar se um único ciclo de digestão seria suficiente para digerir todo o polissacarídeo disponível e, concomitantemente, determinar se a fervura é responsável pela facilitação na ação da segunda enzima);

b) Os dois ciclos de digestão com a presença simultânea de liquenase e xilanase visaram a comparação dos oligossacarídeos formados quando da ação simultânea das enzimas ou em sequência;

c) Os dois ciclos sem qualquer enzima visaram determinar a influência da temperatura de $30^{\circ} \mathrm{C}$ e todo o processo de manipulação do polissacarídeo na formação de oligossacarídeos. 
Tabela 1 - Síntese do desenho experimental da digestão sequencial indicando quais enzimas estavam ativas em cada ciclo de digestão. Período de $0-24 \mathrm{~h}$ corresponde ao primeiro ciclo de digestão e período de 24-48h corresponde ao segundo ciclo de digestão.

\section{$0-24 h$}

24-48h

\begin{tabular}{ccc}
\hline Tratamento A & Liquenase & Xilanase \\
Tratamento B & Xilanase & Liquenase \\
Controle Liquenase & Liquenase & Liquenase \\
Controle Xilanase & Xilanase & Xilanase \\
Controle Simultâneo & Liqu + Xila & Liq + Xila \\
Controle Negativo & Sem enzima & Sem enzima \\
\hline
\end{tabular}

Os oligossacarídeos formados pelas digestões enzimáticas foram analisados em HPAEC-PAD, como descrito acima, porém, anteriormente à análise em HPAEC-PAD dos sobrenadantes recuperados em cada ciclo, estes passaram por uma etapa de precipitação em 3 volumes de etanol, seguida de centrifugação a $2700 \mathrm{~g}$ por 5 minutos onde o sobrenadante coletado foi analisado em HPAEC-PAD.

A precipitação com etanol visou retirar de solução os polissacarídeos não digeridos e fragmentos polissacarídicos de alto peso molecular (Silva, 2001), mantendo em solução somente os oligossacarídeos e polissacarídeos até o peso molecular de cerca de $3000 \mathrm{Da}$., que é o que pode ser normalmente visualizado por HPAEC-PAD.

Na Figura 19 (anexo) se encontra a síntese de todas as atividades realizadas. 


\section{Resultados}

\section{Comparação da composição e estrutura da parede celular de colmo e folha de cana-de-açúcar}

A análise por HPAEC-PAD dos oligossacarídeos formados pelas digestões enzimáticas de paredes celulares (AIR - Alcohol Insoluble Residue) de folha e colmo com xilanase, liquenase e celulase, gerou diferentes perfis de oligossacarídeos.

Os perfis cromatográficos das digestões de colmo e folha com as 3 enzimas se encontram na Figura 6. Apesar da semelhança dos perfis cromatográficos de folha e colmo para cada digestão, é possível verificar algumas diferenças nas intensidades dos picos. Como os ensaios foram feitos com misturas estequiométricas de massa e de enzima, a comparação permite comparar as paredes celulares dos dois órgãos em relação ao acesso que as três diferentes enzimas têm às hemiceluloses, formando oligossacarídeos (Figura 6). Verificou-se que, de maneira geral, celulase e liquenase liberaram proporcionalmente mais oligossacarídeos das paredes de folha do que de colmo. Por outro lado, o tratamento das paredes de AIR como xilanase produziram mais oligossacarídeos a partir do colmo (Figura 6). Considerando que a proporção de arabinoxilanos na parede celular de cana é maior do que de $\beta$-glucano e de xiloglucano, verificou-se, com os dados mostrados na Figura 6 , que o arabinoxilano é bem menos acessível ao ataque enzimático do que o xiloglucano e o $\beta$-glucano. Além disto, como será visto posteriormente, somente oligossacarídeos correspondentes a xilano não ramificado foram detectados.

A digestão de colmo de cana-de-açúcar com celulase (Figura 6 B) gerou quatro picos principais (indicados pelas letras a-d) e um grupo de picos menores (destacados pelo asterisco na figura $6 \mathrm{~B}$ ). Tais picos, em análises posteriores, revelaram ser oriundos de xiloglucanos, tendo sido posteriormente verificado serem (a) glucose, (b) isoprimeverose, (c) celobiose, (d) oligossacarídeo XXG. 
O mesmo pode ser verificado na digestão da folha de cana-de-açúcar, onde foram detectados os mesmos 4 picos principais (mesmos tempos de retenção), porém com uma proporção maior do que em colmo.

Observaram-se picos de xilano (asterisco na Figura 6 B-colmo), quando do tratamento de AIR com celulase. Estes picos de baixa intensidade possuem os mesmos tempos de retenção dos picos de baixa intensidade da digestão de colmo e folha com xilanase entre 7,5 e 12,5 minutos de corrida (Figura 6 D), indicando que ou há contaminação com xilanases na enzima celulase utilizada no ensaio, ou que esta seja capaz, também, de digerir xilanos.

Nas digestões de parede de colmo e folha de cana-de-açúcar com liquenase (Figura $6 \mathrm{C}$ ) foi possível identificar três picos principais, que correspondem a um trissacarídeo, tetrassacarídeo e pentassacarídeo de glucoses (indicados pelas letras e, f, g, respectivamente) (Kato et al., 1986). A intensidade dos três picos correspondentes ao trissacarídeo, tetrassacarídeo e pentassacarídeos é maior na digestão de folha do que na digestão de colmo utilizando a mesma enzima.

A estrutura do $\beta$-glucano (hemicelulose digerida pela ação da liquenase) pôde ser evidenciada pela proporção entre o trissacarídeos e tetrassacarídeo (divisão da área total do pico indicado pela letra e pela área do pico indicado pela letra $f$ na figura $6 \mathrm{C}$ ). Esta proporção é a mesma tanto para colmo, quanto para folha, sendo correspondente a aproximadamente 2:1.

A digestão das paredes celulares de ambos os órgãos com xilanase (Figura 6 D) gerou perfis cromatográficos similares aos o que têm sido exaustivamente descrito na literatura (Ryan et al., 2003, Van Gool et al., 2011). Nestes trabalhos, o padrão tem sido a formação de dois grupos de picos, um sendo composto por xilanos não substituídos e outro com substituições, as quais podem ser com arabinose, ácido glucurônico, acetil ou metil.

A digestão de colmo com xilanase apresentou dois picos com alto tempo de retenção (indicados pelas letras $\mathrm{h}$-i) e os picos indicados pelas setas possuem maior intensidade na digestão de folha do que de colmo.

Os controles sem enzimas (Figura 6 A) apresentam poucos picos e estes de baixa intensidade. Os picos encontrados não possuem os mesmos tempos de retenção de qualquer outro oligossacarídeo produzido nas digestões enzimáticas. 
Com estes resultados foi possível comparar as hemiceluloses presentes na parede celular de colmo e folha de cana-de-açúcar através do diagnóstico da formação de produtos de hidrólise (oligossacarídeos) após digestão com endo-enzimas específicas (liquenase - $\beta$-glucano e xilanase - arabinoxilano).

No entanto, o perfil cromatográfico dos oligossacarídeos formados após digestão com celulase em ambos os materiais (colmo ou folha) não foi característico da presença de xiloglucano de eudicotiledoneas, como descrito em (Tiné et al., 2003), mas característico de Poaceae (Hsieh \& Harris, 2009).

Dessa forma, para a determinação da presença de xiloglucano na parede celular de cana-de-açúcar realizou-se uma injeção de isoprimeverose pura (evidência de xiloglucano, pois se trata de uma glucose ramificada com uma xilose no carbono 6) utilizando o mesmo método de análise em HPAECPAD.

A aplicação em HPAEC-PAD gerou um pico com tempo de retenção de 5,5 minutos (seta na Figura 7), que é mesmo pico b na Figura 6 B.

Executou-se, então, uma coinjeção de isoprimeverose pura (20uM) e glucose pura (10uM) com uma alíquota da digestão de parede celular de colmo com celulase (exatamente a mesma mostrada na Figura 6 B).

O perfil cromatográfico gerado (Figura 8) apresenta o mesmo perfil da figura 6 B colmo, ou seja, o acréscimo destas substâncias não gerou novos picos, demonstrando que essas substâncias já estavam presentes, porém a intensidade de ambos os picos (glicose (a) e isoprimeverose (b)) aumentou na coinjeção quando comparado com a figura $6 \mathrm{~B}$ colmo, reforçando que isoprimeverose está presente na amostra de hidrolizado.

A caracterização dos oligossacarídeos obtidos foi estendida através do uso de espectrometria de massas (MALDI-TOF) conforme será apresentado mais abaixo. 
Colmo

Folha

Controle

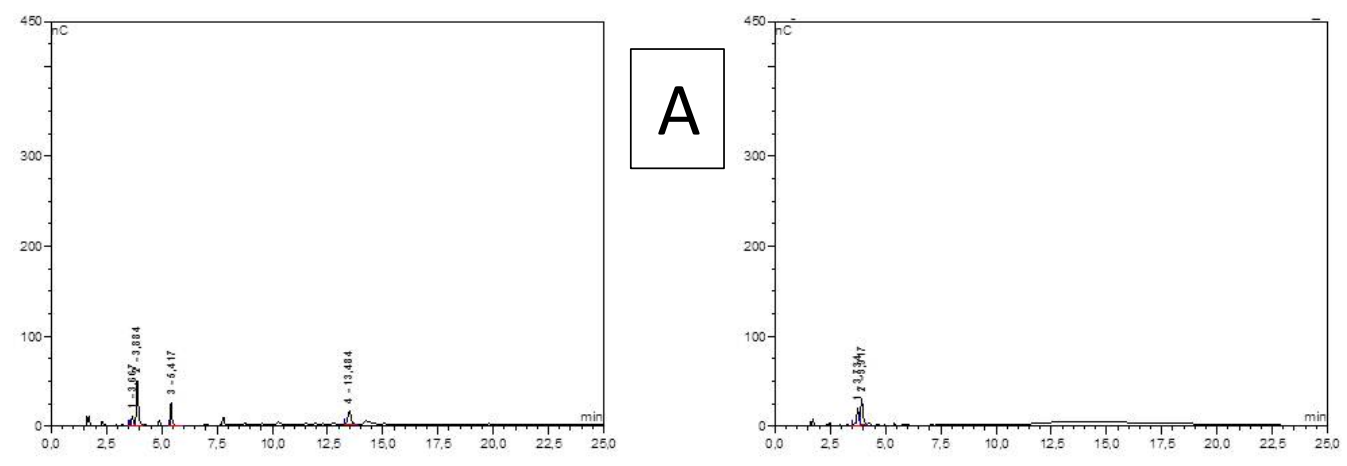

Celulase

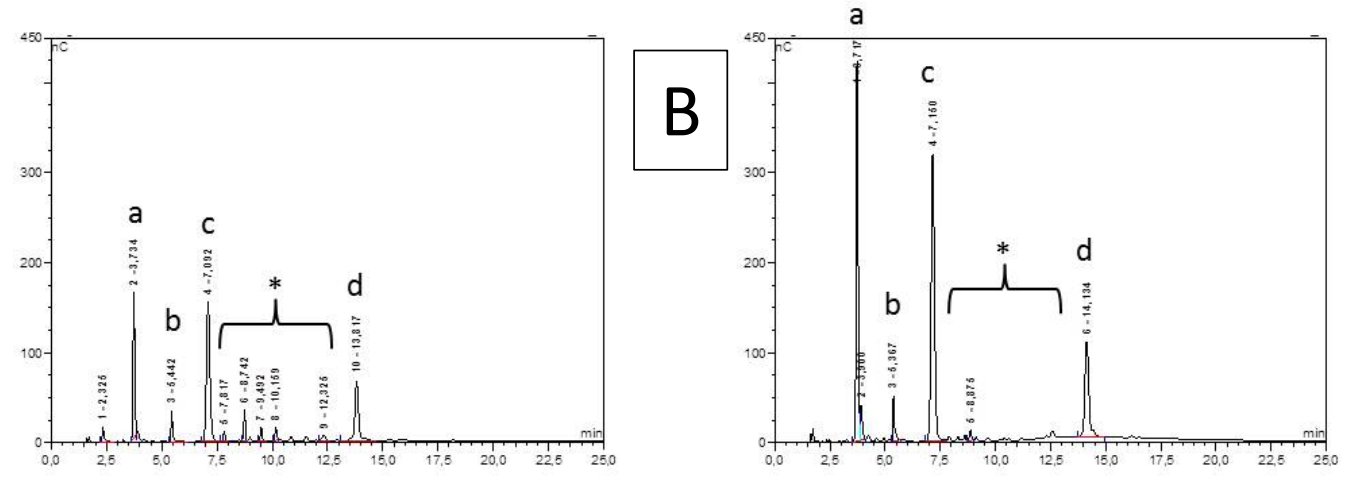

Lichenase

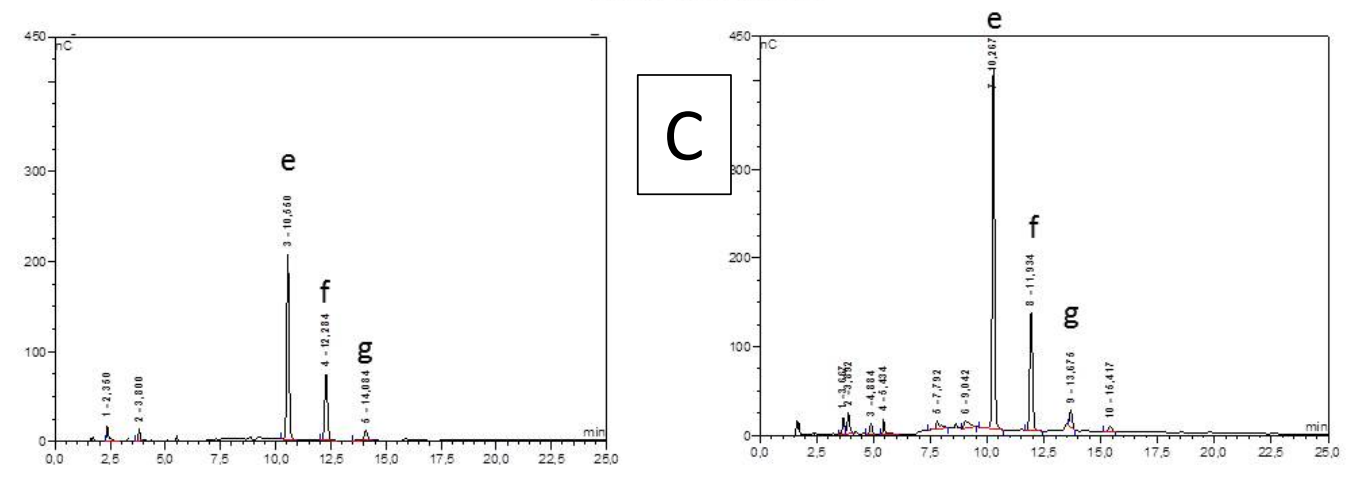

Xilanase

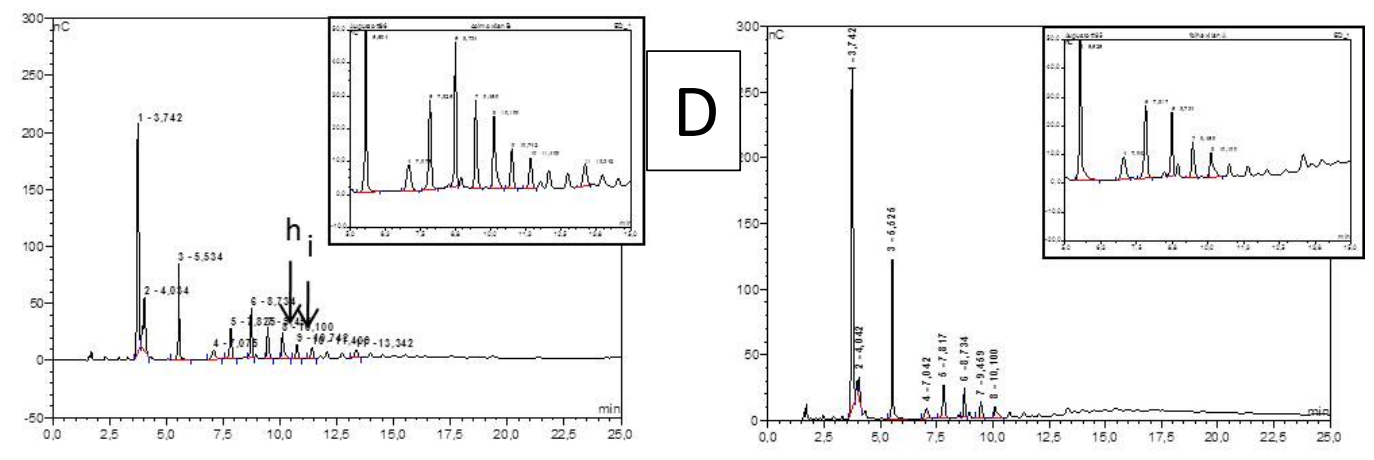


Figura 6 - Digestões de parede celular de colmo e folha, com celulase (B), liquenase (C) ou xilanase (D). (A) controle sem adição de enzima. (B), com a atividade da celulase, são observados fragmentos que podem indicar a presença de xiloglucano: (a) glucose, (b) isoprimeverose, (c) celobiose, (d) oligossacarídeo XXG, $\left({ }^{*}\right)$ picos de retenção semelhantes à digestão com xilanase entre 7,5 a 12,5 minutos. (C), digestão com liquenase observa-se os picos de (e) trissacarídeo, (f) tetrassacarídeo e (g) pentassacarídeos de glucose. (D), a digestão com xilanase produziu uma serie homóloga de oligossacarídeos que lembram fragmentos de xilanos. As digestões ocorreram em pH 5.0, em tampão acetato de amônio e com $0,5 \mathrm{U}$ de enzima. A reação era interrompida com $5 \mathrm{~min}$ de fervura. Os cromatogramas foram obtidos em um HPAEC-PAD Dionex® ICS-3000.

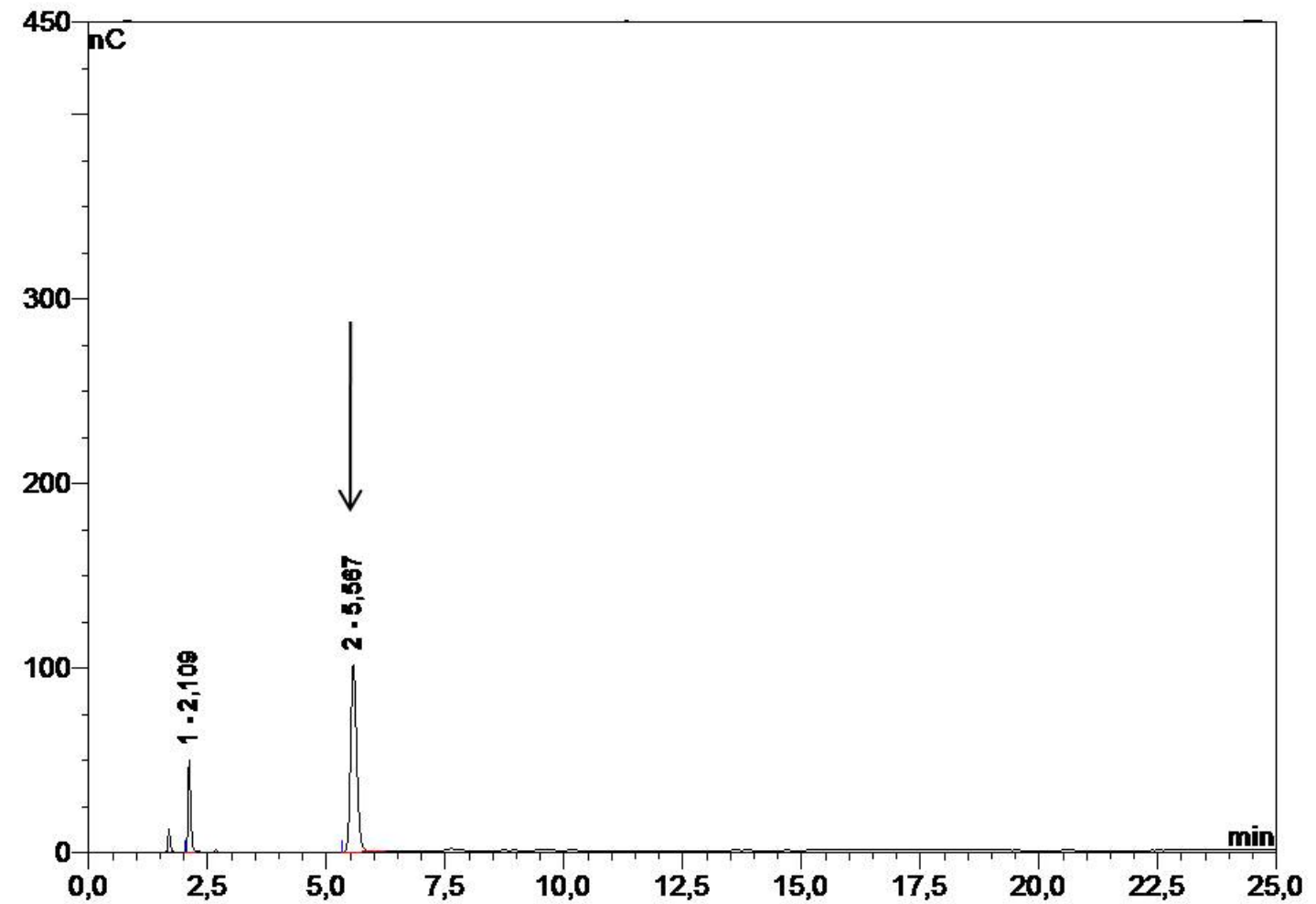

Figura 7 - Injeção de padrão de isoprimeverose indicando um pico preponderante em 5,567 min. O perfil cromatográfico foi obtido em HPAEC-PAD Dionex® ICS-3000, no mesmo programa em que foram corridas todas as outras amostras. 


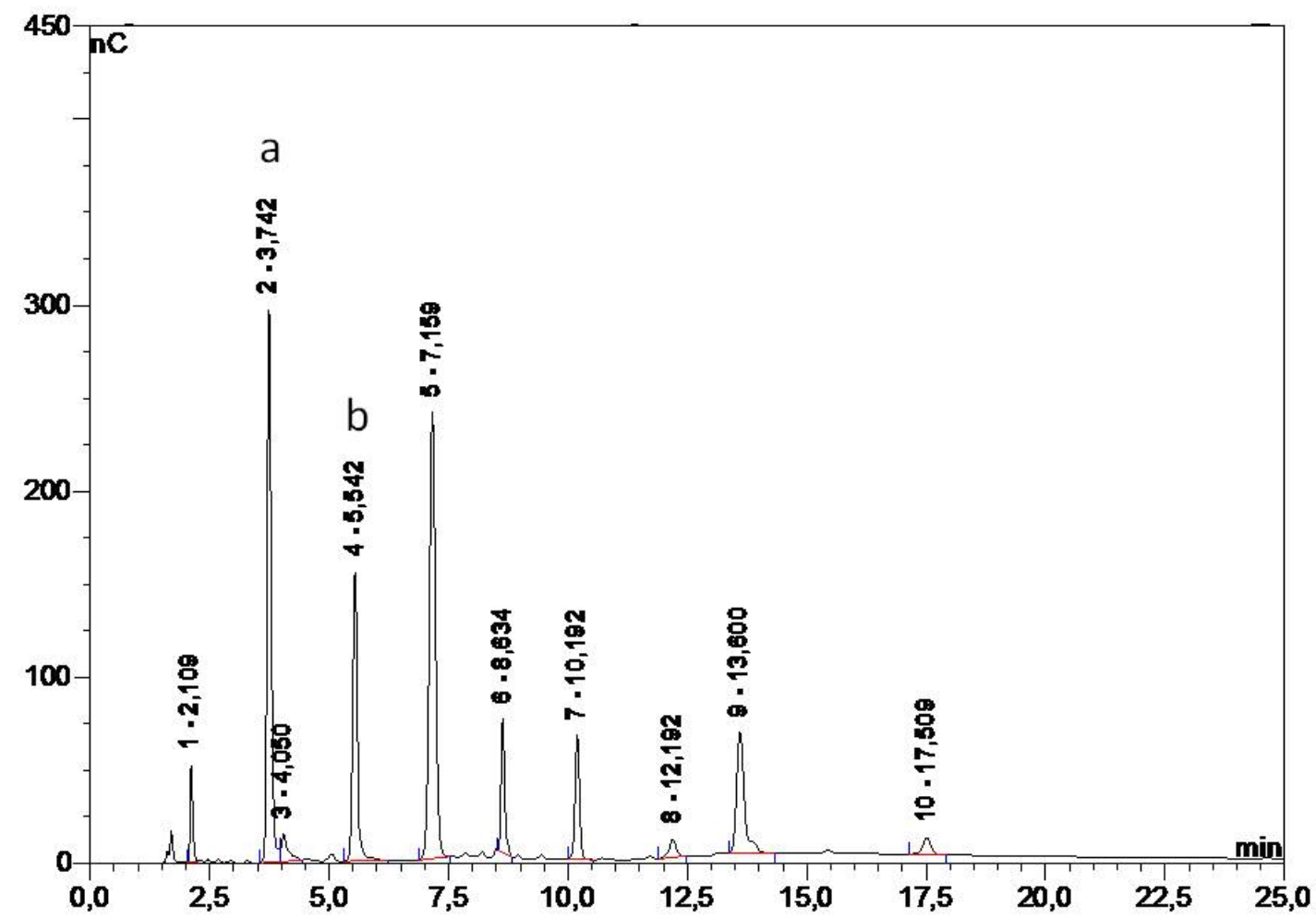

Figura 8 - Coinjeção de glucose e isoprimeverose com amostra de digestão de parede celular de colmo digerido com celulase. Esta coinjeção visou dar suporte à afirmação de que os picos com tempos de retenção de 3,74 (a) e 5,54 (b) são glucose e isoprimeverose respectivamente. O cromatograma foi obtido em um HPAEC-PAD Dionex® ICS-3000, no mesmo programa em que foram corridas todas as outras amostras.

\section{Digestão enzimática sequencial utilizando liquenase e xilanase em parede celular de colmo de cana-de-açúcar.}

A análise por HPAEC-PAD dos oligossacarídeos formados pelas digestões enzimáticas sequenciais de colmo de cana-de-açúcar com liquenase e xilanase gerou perfis cromatográficos, nos quais os picos são formados pelos oligossacarídeos, produzidos na digestão, separados de acordo com o seu tempo de retenção na coluna.

Este é um experimento elaborado com o intento de conhecer algo sobre como os polímeros de hemicelulose podem estar interagindo na parede celular nativa.

$\mathrm{Na}$ figura 9 se encontram os perfis cromatográficos dos controles. $\mathrm{O}$ controle da digestão sequencial sem enzima (Figura $9 A_{1}$ e $A_{2}$ ) apresenta 
somente nas primeiras 24 horas (figura $9 A_{1}$ ) um remanescente de açúcar solúvel representado pelos 2 picos de baixa intensidade.

O controle da digestão sequencial utilizando somente liquenase durante as 48 horas de digestão (Figura $9 \mathrm{~B}_{1}$ e $\mathrm{B}_{2}$ ) apresenta nas primeiras 24 horas (Figura $9 \mathrm{~B}_{1}$ ) a produção de oligossacarídeos, observados como 8 picos, sendo 3 deles (indicados pelas letras a-c) o trissacarídeo, tetrassacarídeo e 0 pentassacarídeo característicos de $\beta$-glucano. A digestão nas 24 horas seguintes (24h-48h) praticamente não há a formação de oligossacarídeos.

O controle da digestão sequencial utilizando somente xilanase durante as 48 horas de digestão (Figura $9 \mathrm{C}_{1} \quad \mathrm{e} \mathrm{C}_{2}$ ) apresenta durante todo $\mathrm{o}$ experimento (48 horas) a formação de oligossacarídeos característicos de arabinoxilano dada a profusão de picos (maior quantidade de sítios de clivagem), embora os oligossacarídeos gerados sejam os mesmos como observado pelo tempo de retenção, estes se encontram em quantidades distintas entre 0-24h (Figura $9 \mathrm{C}_{1}$ ) e 24-48h (Figura $9 \mathrm{C}_{2}$ ).

O perfil cromatográfico das primeiras 24 horas da digestão com xilanase (Figura $9 \mathrm{C}_{1}$ ) apresenta 7 picos de baixa intensidade, enquanto o perfil das seguintes 24 horas (24h-48h) apresenta somente 4 dos picos (Figura $9 \mathrm{C}_{2}$ ), esses em baixa intensidade, com exceção do primeiro com o dobro da quantidade em comparação as primeiras 24 horas.

O último controle da digestão sequencial utilizando ambas as enzimas durante as 48 horas (Figura $9 D_{1}$ e $D_{2}$ ) apresenta produção de oligossacarídeos durante todo o experimento embora a produção seja maior em quantidade e diversidade nas primeiras 24 horas (Figura $9 D_{1}$ ).

A ação concomitante das duas enzimas concomitantemente gerou 2 oligossacarídeos diferentes quando das suas ações individuais (picos indicados pelas setas), um com tempo de retenção de 12,6 minutos, presente nas 48 horas de digestão, e o outro com tempo de retenção de 11,9 minutos, presente somente no segundo ciclo de digestão (24h-48h) (Figura $9 D_{1}$ e $D_{2}$ ).

Os perfis cromatográficos da digestão sequencial estão apresentados na Figura 10. A digestão seqüencial iniciada com liquenase (0-24h) seguida de xilanase (24h-48h) (Figura $10 \mathrm{~A}_{1}$ e $\mathrm{A}_{2}$ ) apresenta nas primeiras 24 horas (Figura $10 \mathrm{~A}_{1}$ ) o mesmo perfil cromatográfico das primeiras 24 horas do controle somente com liquenase (Figura $9 \mathrm{~B}_{1}$ ). Nota-se no segundo período de digestão 
(24h-48h) com xilanase (Figura $10 A_{2}$ ) a presença de um oligossacarídeo com 12,7 minutos de tempo de retenção (indicado pela seta), o mesmo tempo de retenção de um dos picos diferentes presentes no controle com liquenase e xilanase concomitante (Figura $9 D_{1}$ e $D_{2}$ ).

A digestão sequencial iniciada com xilanase (0-24h) seguida de liquenase (24h-48h) (Figura $10 B_{1}$ e $B_{2}$ ) apresenta nas primeiras 24 horas (Figura $10 \mathrm{~B}_{1}$ ) $\circ$ mesmo perfil cromatográfico das primeiras 24 horas do controle somente com xilanase (Figura $9 \mathrm{C}_{1}$ ). Nota-se no segundo período de digestão (24h-48h) com liquenase (Figura $10 \quad \mathrm{~B}_{2}$ ) a presença de dois oligossacarídeos: um com 6,9 minutos de tempo de retenção e outro com 7,9 minutos de tempo de retenção (indicados pelas setas) novos, não estando presentes em quaisquer dos controles.

Observa-se, portanto, que a formação dos oligossacarídeos únicos é dependente da sequência de enzimas utilizada.

Este experimento foi repetido somente uma vez, portanto para incrementar a acurácia dos dados, repetições bem como trata-las estatisticamente seria importante para confirmar as afirmações. 

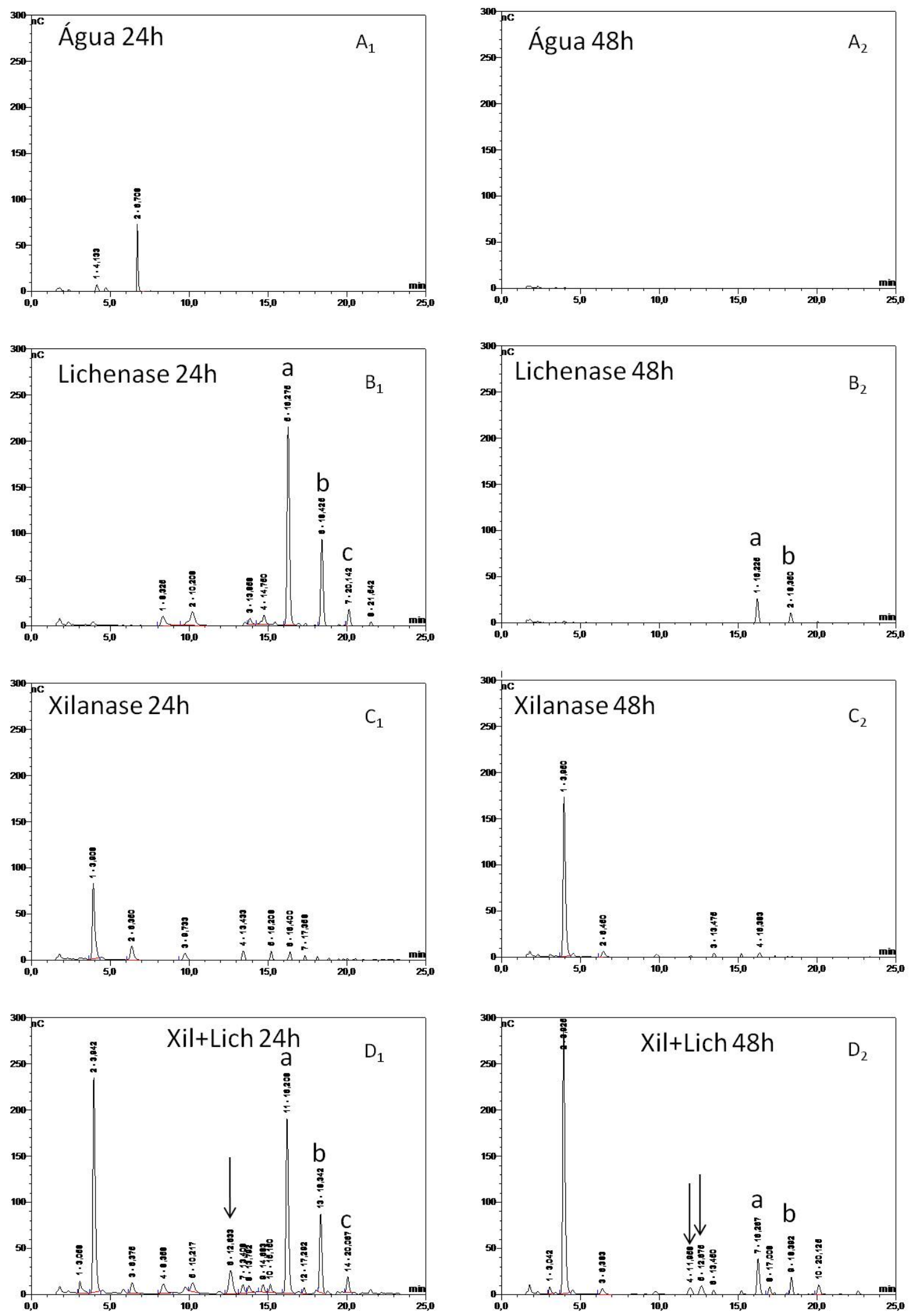

Figura 9 - Controles do experimento da digestão sequencial. Letra ${ }_{1}\left(A_{1}, B_{1}, C_{1}\right.$ e $\left.D_{1}\right)$ corresponde à digestão de 0-24 horas; Letra ${ }_{2}\left(A_{2}, B_{2}, C_{2}\right.$ e $\left.D_{2}\right)$ corresponde à digestão de 24-48 horas. (A) ausência de enzima em ambos os ciclos de digestão; (B) ambos os ciclos de digestão enzimática com Liquenase; (C) ambos os ciclos de digestão enzimática com Xilanase; 
(D) ambos os ciclos de digestão enzimática com Liquenase e Xilanase concomitantemente. (a) trissacarídeo típico de $\beta$-glucano, (b) tetrassacarídeo típico de $\beta$-glucano e (c) pentassacarídeo típico de $\beta$-glucano. $(\rightarrow)$ picos com tempo de retenção únicos do tratamento com lichanase e xilanase concomitante. As digestões ocorreram em pH 5.0, em tampão acetato de amônio e com $0,5 \mathrm{U} / \mathrm{mL}$ de enzima (quando presente). Antes de uma nova enzima ser adicionada, a reação era interrompida com 5 minutos de fervura. Os cromatogramas foram obtidos por HPAEC-PAD Dionex® ICS-3000.

Lichenase $24 \mathrm{~h}$

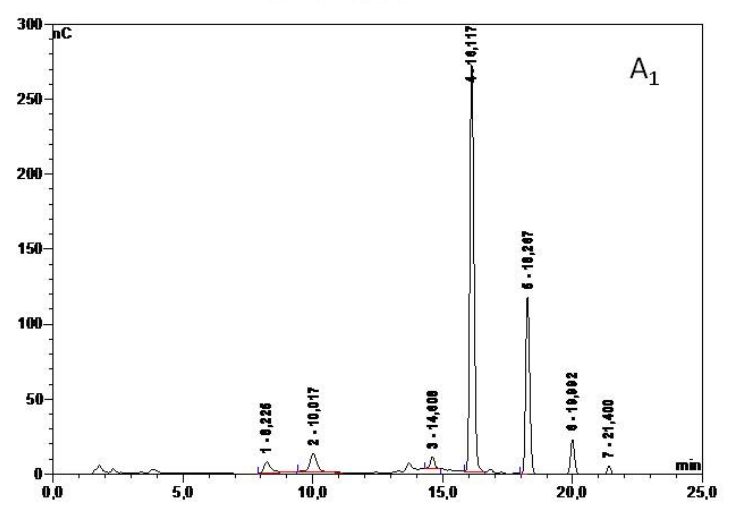

Xilanase $24 \mathrm{~h}$

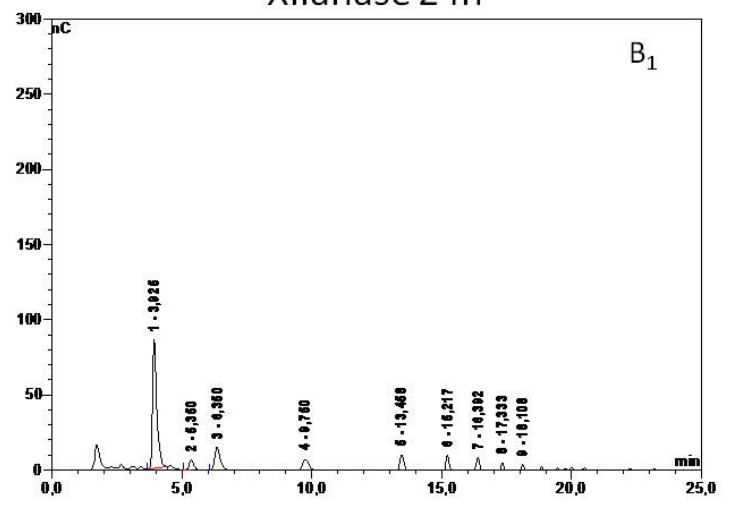

Xilanase $48 \mathrm{~h}$

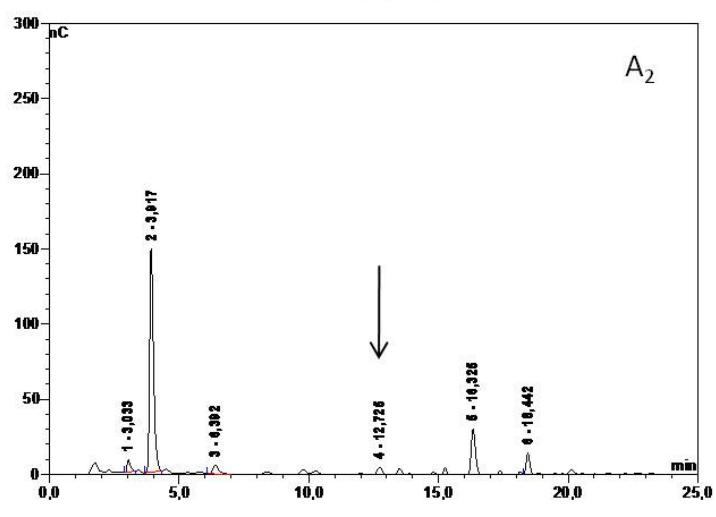

Lichenase $48 \mathrm{~h}$

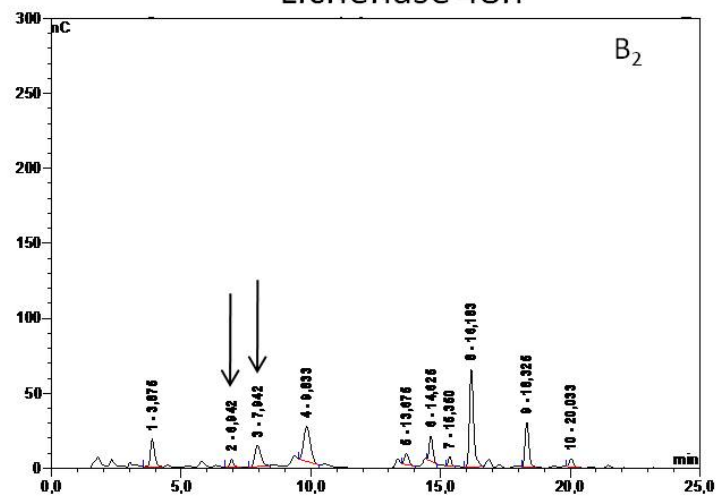

Figura 10 - Digestão seqüencial à amostra de parede celular de colmo de cana-de-açúcar. Letra $_{1}\left(A_{1}, B_{1}, C_{1}\right.$ e $\left.D_{1}\right)$ corresponde à digestão de 0-24 horas; Letra ${ }_{2}\left(A_{2}, B_{2}, C_{2}\right.$ e $\left.D_{2}\right)$ corresponde à digestão de 24-48 horas. (A) digestão seqüencial iniciada (0-24h) com enzima Liquenase $\left(A_{1}\right)$, seguida (24-48h) de digestão com Xilanase $\left(A_{2}\right)$; $(B)$ digestão seqüencial iniciada (0-24h) com enzima Xilanase $\left(B_{1}\right)$, seguida (24-48h) de digestão com Liquenase $\left(B_{2}\right)$. $(\rightarrow)$ picos com tempo de retenção diferentes dos controles com uma única enzima, ou seja, picos novos. As digestões ocorreram em pH 5.0, em tampão acetato de amônio e com 0,5U/mL de enzima. Antes de uma nova enzima ser adicionada, a reação era interrompida com 5 minutos de fervura. Os cromatogramas foram obtidos por análise em HPAEC-PAD Dionex ${ }^{\circledR}$ ICS-3000. 


\section{Análise estrutural dos oligossacarídeos de xiloglucano e arabinoxilanos obtidos por digestão enzimática por espectrométrica de massa (MALDI- TOF)}

Uma vez que os padrão de formação de oligossacarídeos de $\beta$-glucanos é bastante conhecido (Buckeridge et al., 2004), o trabalho de caracterização estrutural das hemiceluloses de folha e colmo de cana seguiu através da caracterização dos xiloglucanos e dos arabinoxilanos, ambos polissacarídeos que apresentam maior complexidade estrutural que o $\beta$-glucano.

Como o xiloglucano se apresenta em pequena proporção em relação aos arabinoxilanos e aos $\beta$-glucanos, foi efetuada uma preparação por fracionamento químico da parede celular de colmo de cana-de-açúcar a qual gerou uma tabela de rendimento (Tabela 2). O colmo foi escolhido como órgão para estudo, devido à sua importância atual como possível fonte de matéria prima (bagaço) para a produção de etanol de segunda geração pela indústria brasileira.

Tabela 2 - Rendimento em açúcares e do fracionamento químico da parede celular de colmo de cana-de-açúcar. Os valores referem-se às massas e suas quantidades relativas na parede celular de colmo de cana-de-açúcar. ( ${ }^{*}$ ) Valor obtido pela subtração da massa inicial do pulverizado de colmo de cana-de-açúcar, 10g, pela quantidade de açúcares solúveis e celulose, portanto, este valor de pectinas provavelmente está superestimado, considerando que durante o processo existe perda de material.

\begin{tabular}{|c|c|c|}
\hline Fração & $\begin{array}{c}\text { Massa } \\
\text { (g) }\end{array}$ & $\begin{array}{c}\text { \% dos açúcares } \\
\text { no colmo }\end{array}$ \\
\hline Açúcares solúveis (fração etanólica) & 2,175 & 21,75 \\
\hline $\begin{array}{l}\text { Fração de polissacarídeos não celulósicos } \\
\text { (frações Oxalato, } \mathrm{NaOH} 0,1 \mathrm{M}, 1 \mathrm{M}, 4 \mathrm{M} \text { ) }\end{array}$ & 3,3 & 33 \\
\hline Pectinas (fração oxalato de amônio)* & $0,9465^{*}$ & $9,46^{*}$ \\
\hline Hemicelulose - Fração $\mathrm{NaOH} 0,1 \mathrm{M}$ & 0,333 & 3,33 \\
\hline Hemicelulose - Fração $\mathrm{NaOH} 1 \mathrm{M}$ & 1,4305 & 14,3 \\
\hline Hemicelulose - Fração $\mathrm{NaOH} 4 \mathrm{M}$ & 0,59 & 5,9 \\
\hline Resíduo (celulose) & 4,525 & 45,25 \\
\hline
\end{tabular}

Como descrito na metodologia, para a realização do fracionamento partiu-se de $10 \mathrm{~g}$ de colmo de cana-de-açúcar pulverizado e encontrou-se 2,3g 
de hemiceluloses totais ( $\beta$-glucano, arabino(xilanos) e xiloglucano), sendo que a fração oxalato de amônio (mais rica em pectinas) compreendeu a 0,94\% do material total.

As hemiceluloses corresponderam a cerca de $23 \%$ dos açúcares presentes no colmo, enquanto que a celulose representou cerca de $45 \%$ e os açúcares solúveis aproximadamente $22 \%$. Vale ressaltar que grande parte do açúcar solúvel presente no colmo da cana-de-açúcar já havia sido extraído pela moagem. Quando se examinam as proporções entre os componentes de parede celular a partir destes dados de fracionamento obtidos, verificam-se $12,1 \%$ de pectinas, $30,1 \%$ de hemiceluloses e $57,8 \%$ de celulose. Estes dados forma obtidos a partir de uma réplica (tabela 2), porém, foram confirmados por outros trabalhos do grupo.

Na Figura 11 se encontram os perfis cromatográficos das hidrólises das frações $1 \mathrm{M}$ e $4 \mathrm{M}$ do fracionamento químico da parede celular de colmo de cana-de-açúcar com xilanase (Figura 11 A e B) e celulase (Figura 11 C e D).

Os perfis cromatográficos das digestões das frações $1 \mathrm{M}$ e $4 \mathrm{M}$ com xilanase (Figura 11 A e B) são semelhantes, no entanto, a digestão da fração $1 \mathrm{M}$ com xilanase (Figura $11 \mathrm{~A}$ ) apresenta uma maior diversidade de oligossacarídeos formados, visualizável pela presença da maior quantidade de picos na região indicada por a, quando comparamos a mesma região, também indicada por a, no perfil cromatográfico da fração 4M (Figura 11 B).

Os oligossacarídeos comuns às digestões das frações $1 \mathrm{M}$ e $4 \mathrm{M}$ com xilanase se apresentaram em intensidades diferentes em ambas as digestões, sendo a intensidade dos picos mais pronunciada na hidrólise da fração $1 \mathrm{M}$ (Figura $11 \mathrm{~A}$ e B).

Nos perfis cromatográficos das digestões das frações $1 \mathrm{M}$ e $4 \mathrm{M}$ com celulase (Figura $11 \mathrm{C}$ e D) também são observadas diferenças na presença e proporção de oligossacarídeos provenientes da digestão de cada fração.

Quando se comparam os cromatogramas referentes à hidrólise das frações $1 \mathrm{M}$ e $4 \mathrm{M}$ com celulase nota-se uma maior diversidade de picos (indicados pelo $b$ ) na hidrólise da fração $1 \mathrm{M}$ (Figura $11 \mathrm{C}$ ). Além disso, é evidente a diferença de intensidade dos oligossacarídeos identificados pelas letras $c, d$ e e entre os dois perfis cromatográficos, enquanto na digestão da 
fração $1 \mathrm{M}$ com celulase o pico e é mais intenso (Figura $11 \mathrm{C}$ ), os picos $c, d$ são mais intensos na digestão da fração 4M com a mesma enzima (Figura $11 \mathrm{D}$ ).

A análise dos oligossacarídeos provenientes da digestão das frações $1 \mathrm{M}$ e 4M do fracionamento de parede celular de colmo de cana-de-açúcar com xilanase e celulase por espectrometria de massas gerou a Tabela 3 , onde se observa as massas de oligossacarídeos íntegros.

Conjuntamente aos dados de massa, também são apresentados os cromatogramas da espectrometria de massa de cada uma das digestões (fração 1M hidrolisada com xilanase; fração 4M hidrolisada com xilanase; fração $1 \mathrm{M}$ hidrolisada com celulase; fração $4 \mathrm{M}$ hidrolisada com celulase) (Figura 12).

Nas espectrometrias de massas dos oligossacarídeos da hidrólise das frações $1 \mathrm{M}$ e $4 \mathrm{M}$ com xilanase (Figura $12 \mathrm{~A}$ e B) nota-se a presença de massa de oligossacarídeos inseridas em retângulos ou indicadas por setas.

Tabela 3: Valores das massas mensuradas pela espectrometria de massa (MALDI-TOF) dos oligossacarídeos provenientes das hidrólises das frações $1 \mathrm{M}$ e $4 \mathrm{M}$ da parede celular de canade-açúcar com Xilanase e Celulase. Os valores de massas foram retirados da Figura 13, sendo as massas indicadas pelos retângulos e setas.

Massas mensuradas

\begin{tabular}{|c|c|c|c|c|c|c|c|c|c|c|c|c|}
\hline $1 \mathrm{M}$ & 569 & 701 & 833 & 965 & 1097 & 1229 & 1361 & 1493 & 1625 & 1757 & 1889 & Retângulos \\
\hline Xilanase & - & 759 & 891 & 1023 & 1155 & 1287 & 1419 & 1551 & - & - & - & Setas \\
\hline 4M & 569 & 701 & 833 & 965 & 1097 & - & - & - & - & - & - & Retângulos \\
\hline Xilanase & - & - & 891 & - & 1155 & - & - & - & - & - & - & Setas \\
\hline \multicolumn{13}{|c|}{ Massas mensuradas } \\
\hline \multicolumn{13}{|l|}{$1 \mathrm{M}$} \\
\hline Celulase & - & 791 & - & 953 & - & - & - & - & - & - & - & Retângulos \\
\hline \multicolumn{13}{|l|}{$4 M$} \\
\hline Celulase & - & 791 & - & 953 & 1085 & 1115 & 1247 & 1379 & - & - & & Retângulos \\
\hline
\end{tabular}

As massas mensuradas e delimitadas pelo retângulo variam, entre si, na forma de uma progressão aritmética, sempre com o acréscimo de 132 em sua massa. Dessa forma, as massas encontradas para os oligossacarídeos, delimitadas pelo retângulo, variam de 569 a 1889 sempre somando 132 a 
massa inicial de 569 na fração 1M (Figura 12 A) e variam de 569 a 1097 sempre somando 132 a massa inicial de 569 na fração 4M (Figura 12 B).

Da mesma forma, as massas mensuradas e indicadas pelas setas variam entre si na forma de uma progressão aritmética sempre com o acréscimo de 132 a sua massa, no entanto, as massas indicadas pelas setas variam de 759 a 1551 na fração $1 \mathrm{M}$ e de 891 a 1155 na fração 4M (Figura $12 \mathrm{~A}$ e B). Estas diferenças com massa equivalentes a múltiplos de 132 são características de polímeros constituídos por pentoses, indicando a fragmentação de um polissacarídeo de xilano/arabinoxilano, já que a enzima adicionada foi uma endo- $\beta$-xilanase.

Nas espectrometrias de massas dos oligossacarídeos da hidrólise das frações $1 \mathrm{M}$ e $4 \mathrm{M}$ com celulase (Figura $12 \mathrm{C}$ e D) nota-se a presença de massas de oligossacarídeos inseridas em retângulos.

Diferentemente das massas mensuradas dos oligossacarídeos da hidrólise com xilanase, a variação das massas encontradas dos oligossacarídeos provenientes das hidrólises com celulase, tanto da fração $1 \mathrm{M}$ quanto da fração $4 \mathrm{M}$, não se dá da mesma forma, sempre com o acréscimo de um mesmo valor a massa (Tabela 3). Notou-se um acréscimo ora de 132 a massa ora de 162 a massa anterior.

Os demais picos encontrados e não evidenciados por retângulos ou por setas, em quaisquer cromatogramas, ou se tratam de fragmentos de oligossacarídeos ou oligossacarídeos não pertinentes à análise, provenientes de contaminação, como os picos de massa 689 (4 hexoses) (Figura $10 \mathrm{C}$ e D) e 851 (5 hexoses) (Figura 12 D).

Ainda referindo-se às digestões com xilanase da fração $1 \mathrm{M}$ e a análise destas em MALDI-TOF, percebe-se, intercalando-se com a escada de pentoses da digestão da fração $1 \mathrm{M}$ (indicado por retângulos na figura $12 \mathrm{~A}$ ), massas que poderiam também consistir em uma escala crescente de massas de 759 a 1551 (indicado por setas na figura $12 \mathrm{~A}$ ).

Analisando as possibilidades para a massa de 759, temos: 3 pentoses (massa 569), 1 fucose (massa 146) e uma molécula de ácido urônico (massa 176). Dessa forma, a escala crescente sempre teria uma pentose sendo acrescida até atingir a massa de 1551. 
Resultados não descritos neste trabalho foram executados para identificar a molécula responsável pela escala de massa de 759-1551. Porém, a conclusão destes experimentos indicou serem oligossacarídeos provenientes de contaminação da xilanase Sigma utilizada. 

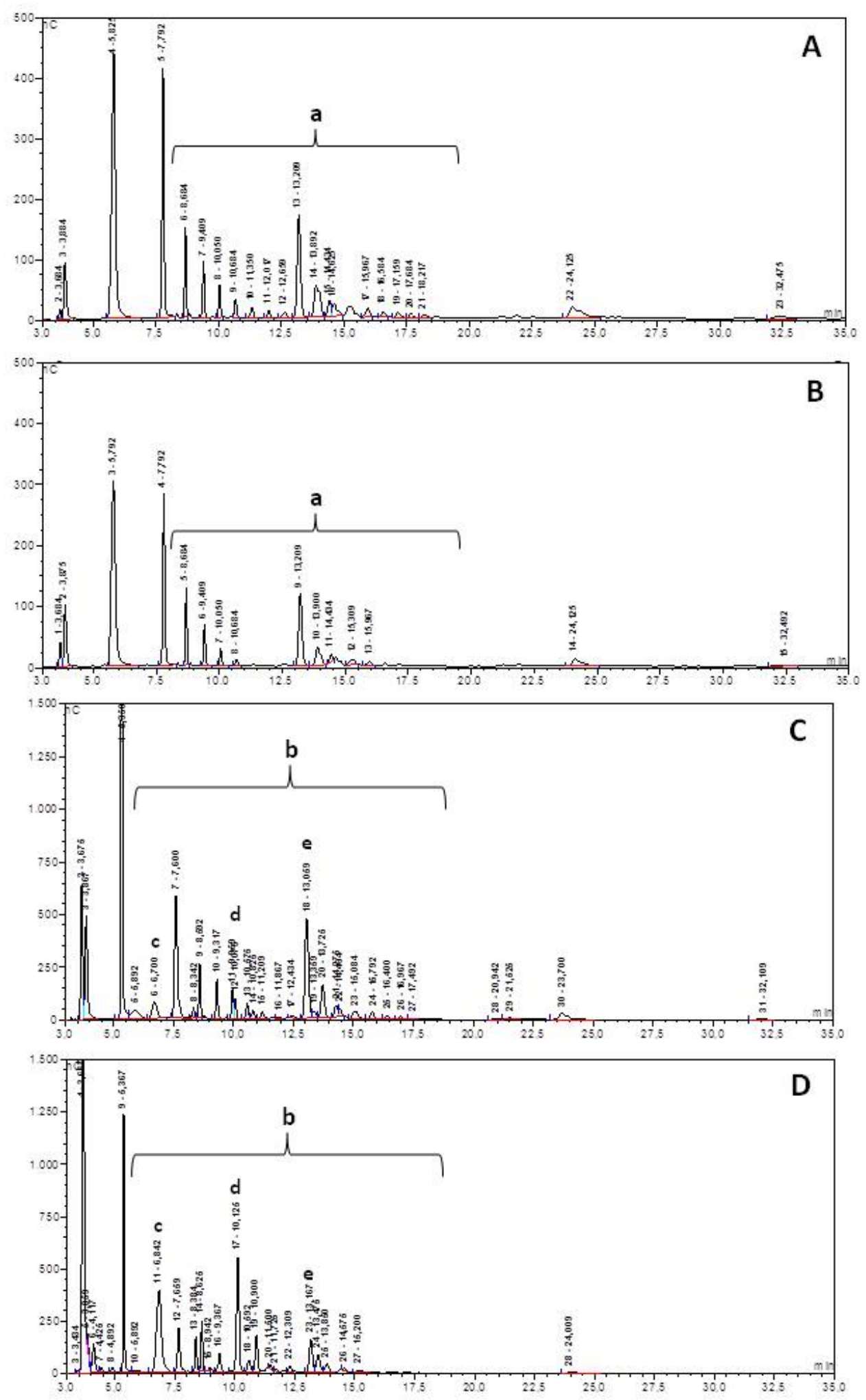

Figura 11 - Perfis cromatográficos das hidrólises enzimáticas das frações $1 \mathrm{M}$ e $4 \mathrm{M}$ da parede celular de colmo de cana-de-açúcar com as enzimas xilanase (A e B) e celulase (C e D). (A) Perfil dos oligossacarídeos provenientes da digestão da fração 1M com Xilanase; (B) Perfil dos oligossacarídeos provenientes da digestão da fração 4M com Xilanase; (C) Perfil dos 
oligossacarídeos provenientes da digestão da fração $1 \mathrm{M}$ com Celulase; (D) Perfil dos oligossacarídeos provenientes da digestão da fração 4M com Celulase. (a) Oligossacarídeos com diversidade e intensidade diferentes entre (A) e (B); (b) Oligossacarídeos com diversidade e intensidade diferentes entre (C) e (D); (c), (d), (e) principais oligossacarídeos que apresentam diferenças de intensidade entre (C) e (D).
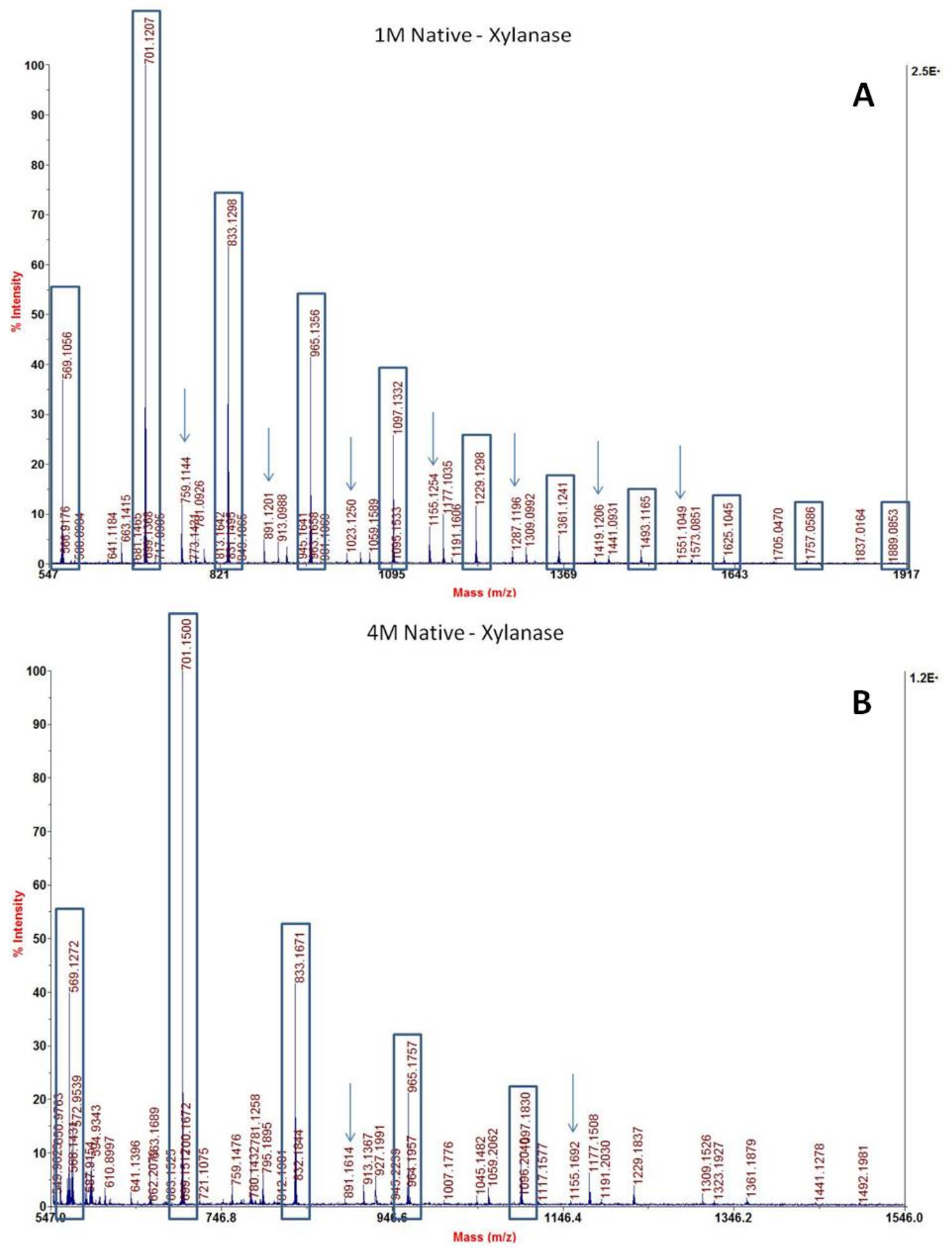


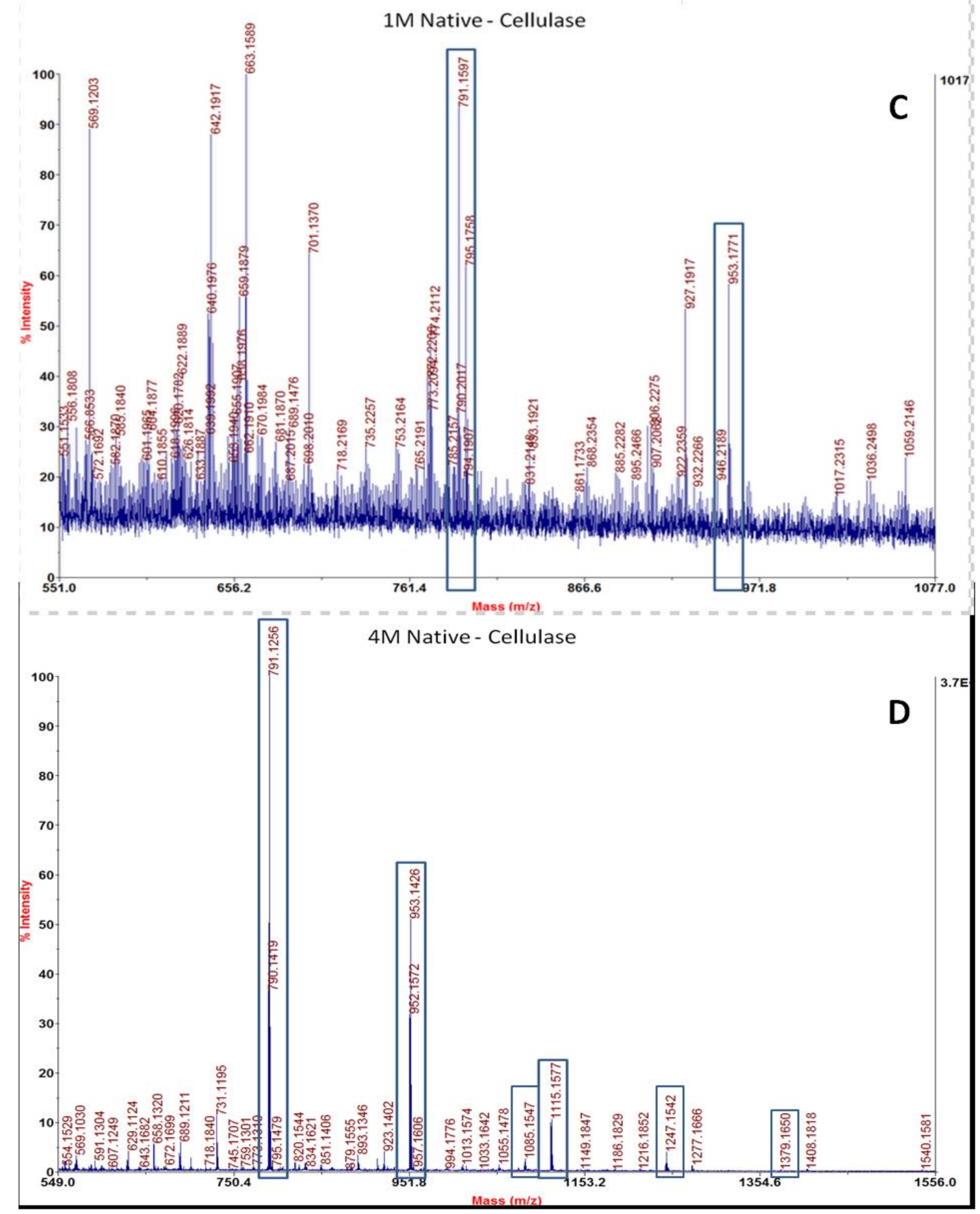

Figura 12 - Cromatogramas da espectrometria de massas (MALDI-TOF) das hidrólises enzimáticas das frações $1 \mathrm{M}$ e $4 \mathrm{M}$ da parede celular de colmo de cana-de-açúcar com as enzimas xilanase (A e B) e celulase (C e D). (A) Perfil das massas dos oligossacarídeos provenientes da digestão da fração $1 \mathrm{M}$ com Xilanase, sendo os retângulos em sequência Pentose 5 até Pentose 14; (B) Perfil das massas dos oligossacarídeos provenientes da digestão da fração $4 \mathrm{M}$ com Xilanase, sendo os retângulos em sequência Pentose 4 até Pentose 9 ; (C) Perfil das massas dos oligossacarídeos provenientes da digestão da fração $1 \mathrm{M}$ com Celulase, sendo os retângulos em sequência XXG, XXGG; (D) Perfil das massas dos 
oligossacarídeos provenientes da digestão da fração $4 \mathrm{M}$ com Celulase, sendo os retângulos em sequência XXG, XXGG, XXGGG/XLGG, XXXG, XLXG/XXLG e XXXXG. Retângulos e Setas em A e B: massas mensuradas que variam, entre si, na forma de uma progressão aritmética, sempre com o acréscimo de 132 a massa anterior; Retângulo em C e D: massas mensuradas que não variam, na forma de uma progressão aritmética, ora a o acréscimo de 132 , ora de 162 a massa anterior.

\section{Análise estrutural dos oligossacarídeos produzidos pela digestão enzimática das frações 1 e $4 M$ por PACE}

Com a finalidade de aumentar o conhecimento sobre a estrutura dos arabinoxilanos presentes na parede celular de colmo de cana-de-açúcar, os oligossacarídeos provenientes da digestão da fração $1 \mathrm{M}$ e $4 \mathrm{M}$ com xilanase foram, purificados por Cromatografia em Camada Delgada (TLC) preparativa e, posteriormente, analisadas por PACE. Na figura 13, é demonstrado a revelação da TLC da fração 4M. 


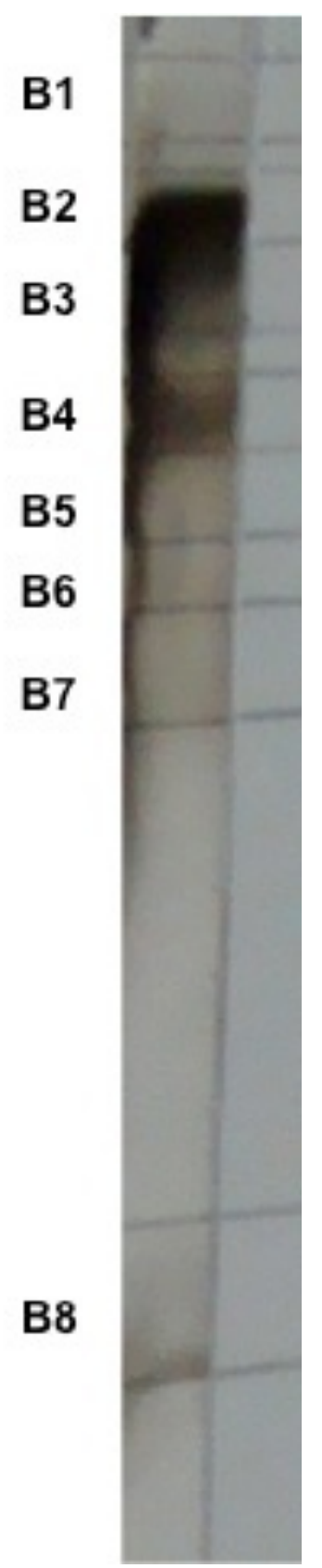

Figura 13 - Corrida preparativa de TLC. Local onde as bandas foram reveladas, visando determinar em que local a sílica deveria ser raspada para que se isolassem os oligossacarídeos. Digestão com xilanase da fração $4 \mathrm{M}$ da parede celular de colmo de cana-deaçúcar.

Anteriormente à análise por PACE, os oligossacarídeos purificados provenientes de ambas as digestões com xilanase (Fração 1M e Fração 4M) foram submetidos à análise por HPAEC-PAD visando checar à máxima pureza possível de cada banda purificada (figura 14 e 15). 

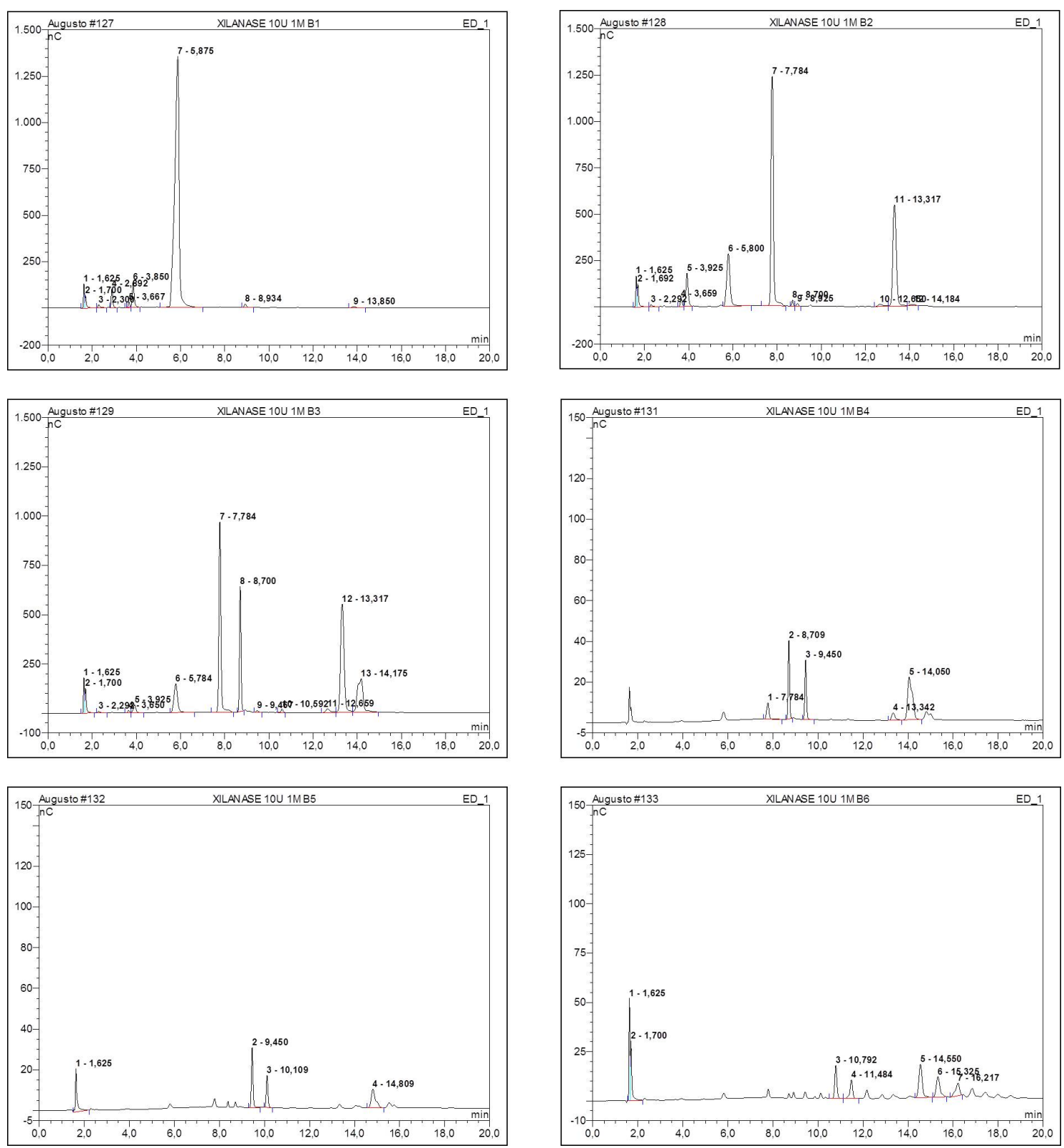

Figura 14 - Cromatografia de troca aniônica de alta performance (HPAEAC-PAD) de cada uma das 6 bandas raspadas da TLC da digestão com xilanase da fração $1 \mathrm{M}$, Notar que a escala das bandas 4,5 e 6 é 10 vezes menor que da banda 1,2 e 3, para melhor visualização. 

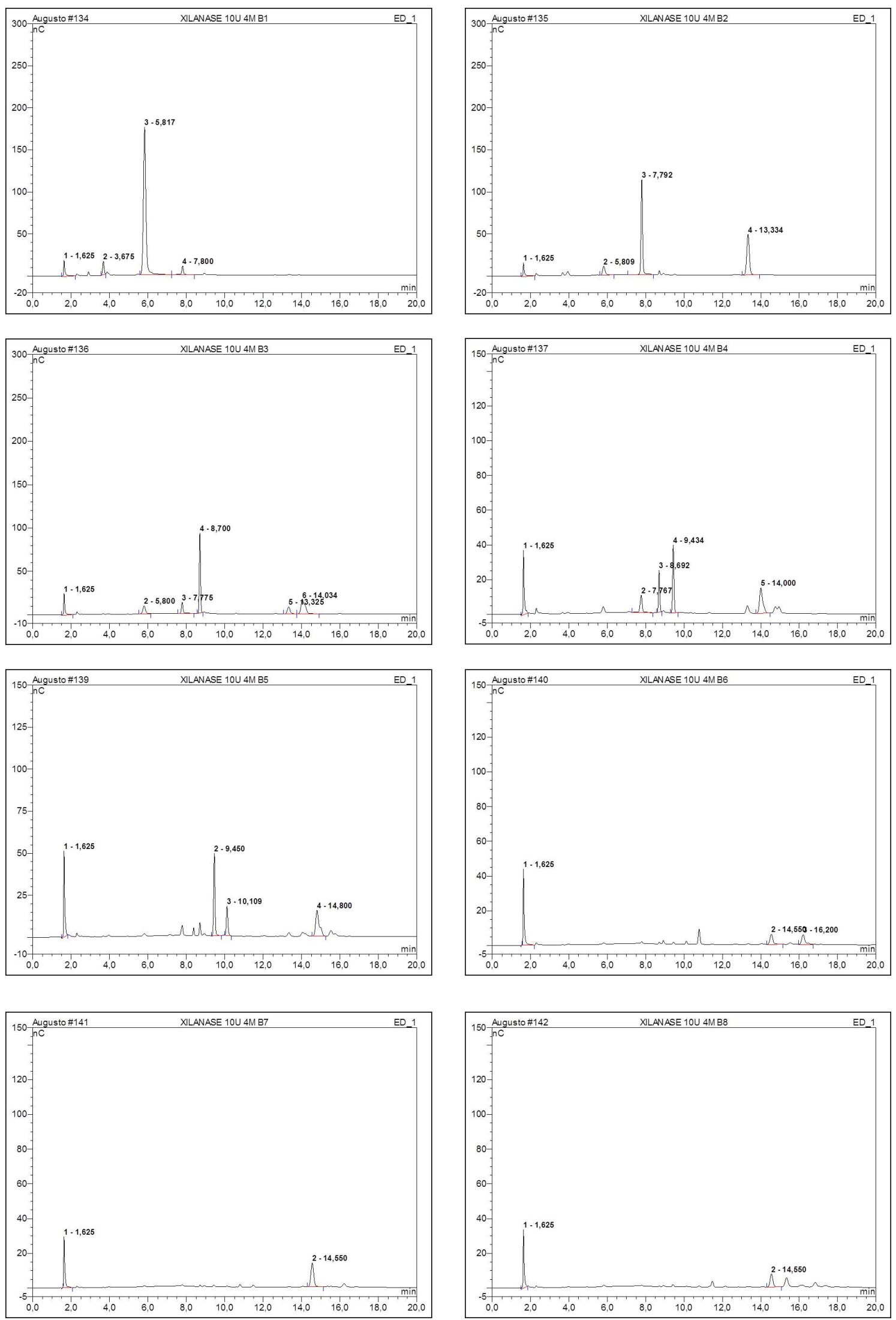

Figura 15 - Cromatografia de troca aniônica de alta performance (HPAEAC-PAD) de cada uma das 8 bandas raspada na TLC da digestão com xilanase da fração 4M. Notar que a escala das bandas 4, 5, 6, 7 e 8 é 2 vezes menor que da banda 1, 2 e 3, para melhor visualização. 
A digestão com xilanase da fração $1 \mathrm{M}$ gerou na TLC 6 bandas (oligossacarídeos), enquanto que a digestão com a mesma enzima da fração $4 \mathrm{M}$ gerou 8 bandas. Em ambas as TLCs, as bandas foram numeradas de acordo com a sua altura na placa e com o tamanho do oligossacarídeo, ou seja, Banda 1 é a banda mais alta (oligossacarídeos de menor tamanho), enquanto a 8 é a mais baixa (oligossacarídeos de maior tamanho).

Assim, cada uma das bandas foi purificada e analisada em HPAECPAD, estando os perfis cromatográficos na figura 14 e 15.

Nenhuma das bandas isoladas por TLC se mostrou pura, ou seja, sempre mais de um pico representando fragmento de oligossacarídeos foi detectado pelo sensor do HPAEC-PAD. As bandas 1 e 2 da digestão $1 \mathrm{M}$ e as bandas 1, 2 e 3 da digestão $4 \mathrm{M}$ com xilanase mostraram-se mais puras, ou seja, com menor quantidade de picos (Figura 14 e 15). Nestes casos, os tempos de retenção dos picos mais intensos (por volta de 100-1000nC de amplitude de detecção) foram Bandas 1 e 2 da fração $1 \mathrm{M}$ e Bandas 1, 2 e 3 da fração 4M.

Uma vez que o isolamento dos oligossacarídeos não foi possível por TLC, a espectrometria de massas por MALDI-TOF não poderia ser utilizada nestas amostras, pois não seria possível correlacionar as massas encontradas com o oligossacarídeos na mistura. Dessa forma, optou-se pela técnica do PACE, uma metodologia alternativa às análises por HPAEC-PAD, e que também possibilita a análise de misturas de oligossacarídeos, mas permitindo $O$ rápido isolamento de quantidades suficientes de oligossacarídeos puros para análises por espectrometria de massas.

Os géis de poliacrilamida do PACE das análises dos oligossacarídeos semi-purificados das digestões das frações $1 \mathrm{M}$ e $4 \mathrm{M}$ se encontram nas Figuras 16 e 17 , respectivamente.

Em ambas as análises (Figura 16 e 17) observa-se que as bandas isoladas a partir do TLC são compostas por diversos oligossacarídeos. Além disso, em ambas as análises, porém mais evidente nas bandas purificadas da digestão da fração $1 \mathrm{M}$, notam-se oligossacarídeos com migração semelhante ao padrão de oligossacarídeos tendo entre duas a 6 unidades de xilose (Figura 16 e 17 - bandas destacadas em retângulos). 
A fração $1 \mathrm{M}$, que foi a mais abundante do colmo, perfazendo $14 \%$ dos açúcares deste, apresentou um padrão bastante variado de bandas, denotando a alta complexidade da estrutura fina dos arabinoxilanos do colmo de cana. As variações são semelhantes entre $1 \mathrm{M}$ e $4 \mathrm{M}$, mas na primeira, foi possível observar grande variabilidade principalmente nas bandas B5 e B6.

Com estes dados, foi possível analisar uma proporção considerável dos polissacarídeos, uma vez que os padrões de xilano revelam a estrutura de vários oligossacarídeos. Além disto, o uso de duas arabinofuranosidases das classes GH51 e GH62 possibilitou avançar no conhecimento das estruturas de alguns dos demais oligossacarídeos que aparecem em alta intensidade em PACE.

Além disso, as bandas com menor migração no TLC (B4 a B8) apresentam maior diversidade de oligossacarídeos (Figura 16 e 17).

Após as análises em PACE das bandas isoladas de ambas as digestões, as bandas 1, 3 e 4 isoladas por TLC das digestões com xilanase das frações $1 \mathrm{M}$ e $4 \mathrm{M}$, foram submetidas a novas digestões com 2 arabinofuranosidases (família GH51 e GH62) (Figura 18 A e B).

A Figura 18 A mostra a digestão com $\mathrm{CH} 51$ e $\mathrm{CH} 62$ das bandas isoladas por TLC B1 e B3 da digestão da fração 1M com xilanase. Observa-se que as bandas apresentadas pela Banda 1 controle (B1 undige) não se modificaram quando da presença das arabinofuranosidases (B1 gh51 e B1 gh62).

Por outro lado, a Banda 3 (isolada por TLC a partir da Fração 1M) controle (B3 undige), apresentou uma banda (indicada pela seta e letra $A$ ), suscetível ao ataque das arabinofuranosidases (B3 gh51 e B3 gh62) que desapareceu. Como consequência, observou-se o aparecimento de novas bandas, indicadas pelos retângulos $B$ e $C$ (B3 gh51 e B3 gh62) que correspondem à xilobiose (Figura $18 \mathrm{~A}$ ).

Considerando que a banda $\mathrm{A}$ da Figura $18 \mathrm{~A}$ está em uma posição entre os oligossacarídeos xilopentaose e xilohexaose, e que uma banda equivalente à xilobiose aparece após a hidrolise com as arabinofuranosidases, a banda $\mathrm{A}$ poderia ser composta por uma xilobiose contendo três ramificações com arabinose. Neste caso, portanto, só seriam possíveis uma ramificação dupla e uma simples com arabinose, não sendo possível definir no caso da ramificação simples, se esta estaria ligada ao carbono 2 ou 3 da xilose. Isto porque já foi 
demonstrado que as duas enzimas, GH51 (Sorensen et al., 2006) e GH62 (Sakamoto et al., 2011), são capazes de hidrolisar ambas as ligações glicosídicas ( $\alpha-1,2$ e $\alpha-1,3)$ das ramificações de arabinoxilanos.

Ainda na Banda 3 , um conjunto de 3 oligossacarídeos que estão entre xilohexaose e xiloheptaose desaparecem quando submetidos à hidrolise com GH52 ou GH62. É notável ainda o fato de que após tratamento com estas duas enzimas, sobram principalmente xilobiose a xilohexaose como oligossacarídeos predominantes.

A Banda 4 (Fração 1M) obtida por TLC da digestão da fração $1 \mathrm{M}$ com xilanase se encontram na Figura $18 \mathrm{~B}$, onde pode-se observar o aparecimento de uma banda quando da presença das arabinofuranosidases, indicada pelo retângulo $D$ (B4 gh51 e B4gh62), inexistente na amostra sem a presença das arabinofuranosidases (B4 undige).

$\mathrm{Na}$ Figura $18 \mathrm{~B}$, onde se encontram as bandas purificadas em TLC B1, B3 e B4 da digestão da fração 4M com xilanase, observa-se que as bandas apresentadas pela Banda 1 não digerida com arabinofuranosidase (B1 undige) não se modificam quando da presença das arabinofuranosidases (B1 gh51 e $B 1$ gh62), com exceção da banda, indicada pela seta e letra $E$, que está presente no material não digerido pela arabinofuranosidase (B1 undige), mas ausente quando da presença das arabinofuranosidases (B1 gh51 e B1 gh62).

A Banda 3 da fração $4 \mathrm{M}$ quando digerida com as arabinofuranosidases apresentou o surgimento de uma banda, indicada pelo retângulo $F$ (B3 gh51 e B3gh62), que correu no tempo de retenção dos monossacarídeos e possivelmente se refere à xilose e arabinose. É possível portanto que o oligossacarídeo que corre com um dissacarídeo logo acima da do retângulo $F$, seja uma xilose ligada a uma arabinose e quando atacada por GH51 ou Gh62 produz monossacarídeo livres (arabinose e xilose).

A Banda 4 (Fração 4M), quando digerida com as arabinofuranosidases apresentou o surgimento de dois compostos: um deles, indicado pelo retângulo $H$ (B4 gh51 e B4gh62) e que tem Rf na faixa dos monossacarídeos. O outro, indicado pela seta e letra $J$ (B4 gh51 e B4gh62), parece ser um oligossacarídeo, mas é extremamente difícil deduzir, com base nos resultados obtidos, qual poderia ser a composição deste composto. 


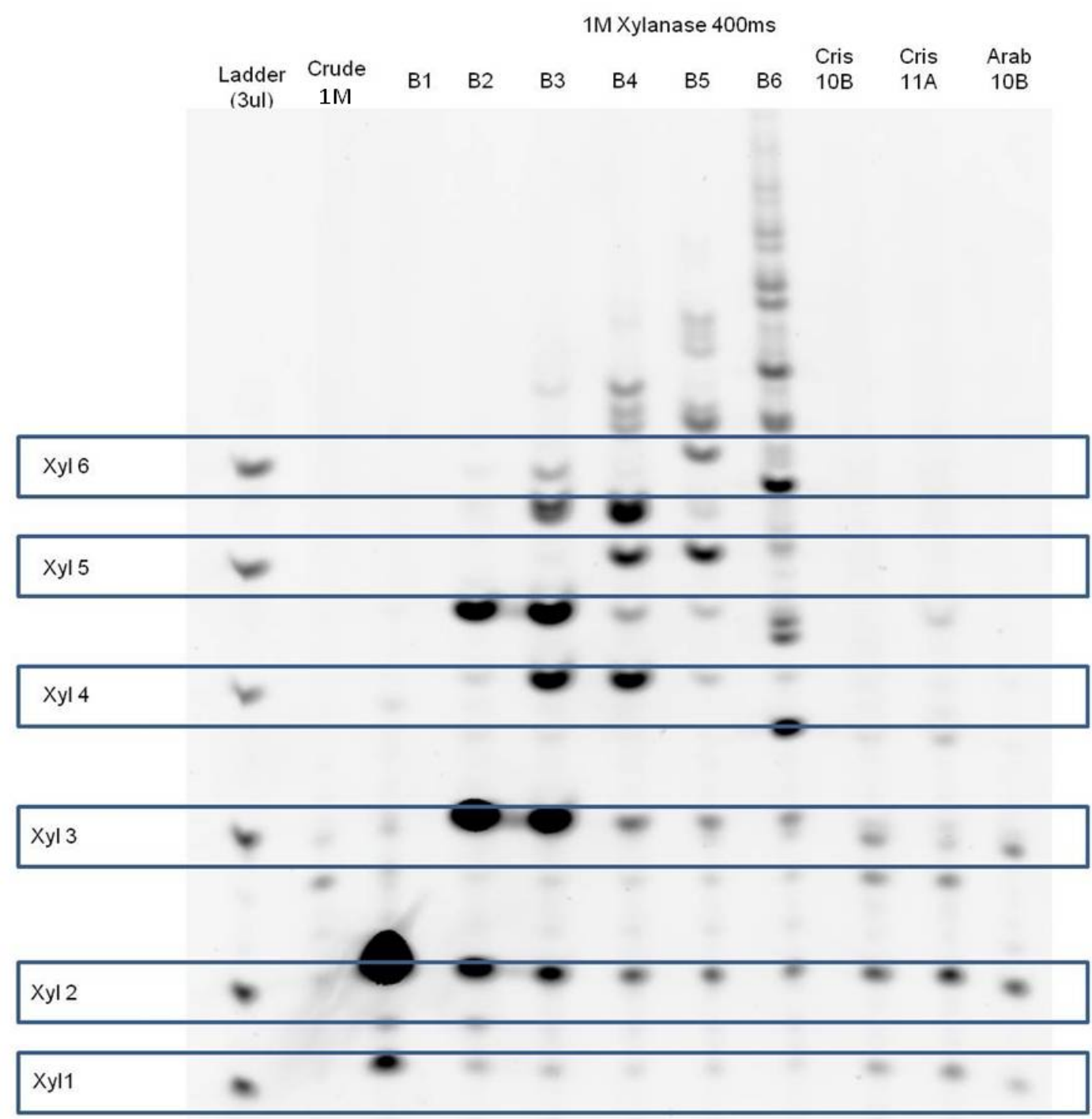

Figura 16 - Gel de Poliacrilamida de PACE das bandas purificadas em TLC da hidrólise enzimática da fração $1 \mathrm{M}$ com Xilanase. (Ladder) Padrão de oligossacarídeos de xilano com número de resíduos conhecidos, variando de 1 xilose a 6 xiloses; (Crude 1M) Fração $1 \mathrm{M}$ não digerida com a xilanase; (B1 a B6) Bandas purificadas em TLC da hidrólise enzimática da fração 1M com Xilanase, onde B1 migrou mais na placa de sílica (TLC), ou seja, ficou mais alta em relação a base e a $\mathbf{B 6}$ teve a menor migração na placa de sílica (TLC); Retângulo: oligossacarídeos das bandas "purificadas" com migração semelhante ao padrão de oligossacarídeos de xilano. 


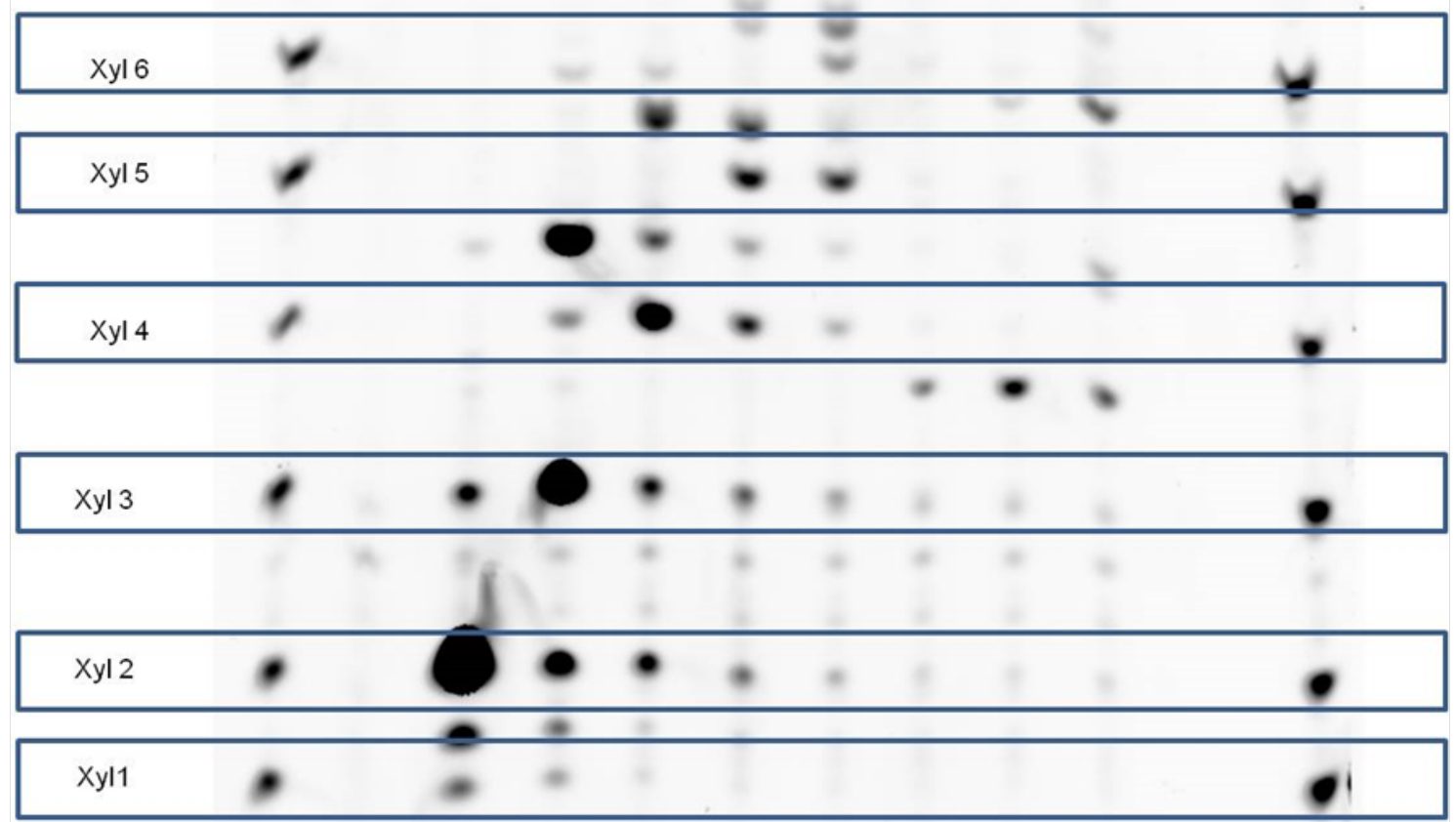

Figura 17 - Gel de Poliacrilamida de PACE das bandas purificadas em TLC da hidrólise enzimática da fração $4 \mathrm{M}$ com Xilanase. (Ladder) Padrão de oligossacarídeos de xilano com número de resíduos conhecidos, variando de 1 xilose a 6 xiloses; (Crude 4M) Fração 4M não digerida com a xilanase; (B1 a B8) Bandas purificadas em TLC da hidrólise enzimática da fração 1M com Xilanase, onde B1 migrou mais na placa de sílica (TLC), ou seja, ficou mais alta em relação a base e a B8 teve a menor migração na placa de sílica (TLC); Retângulo: oligossacarídeos das bandas "purificadas" com migração semelhante ao padrão de oligossacarídeos de xilano. 


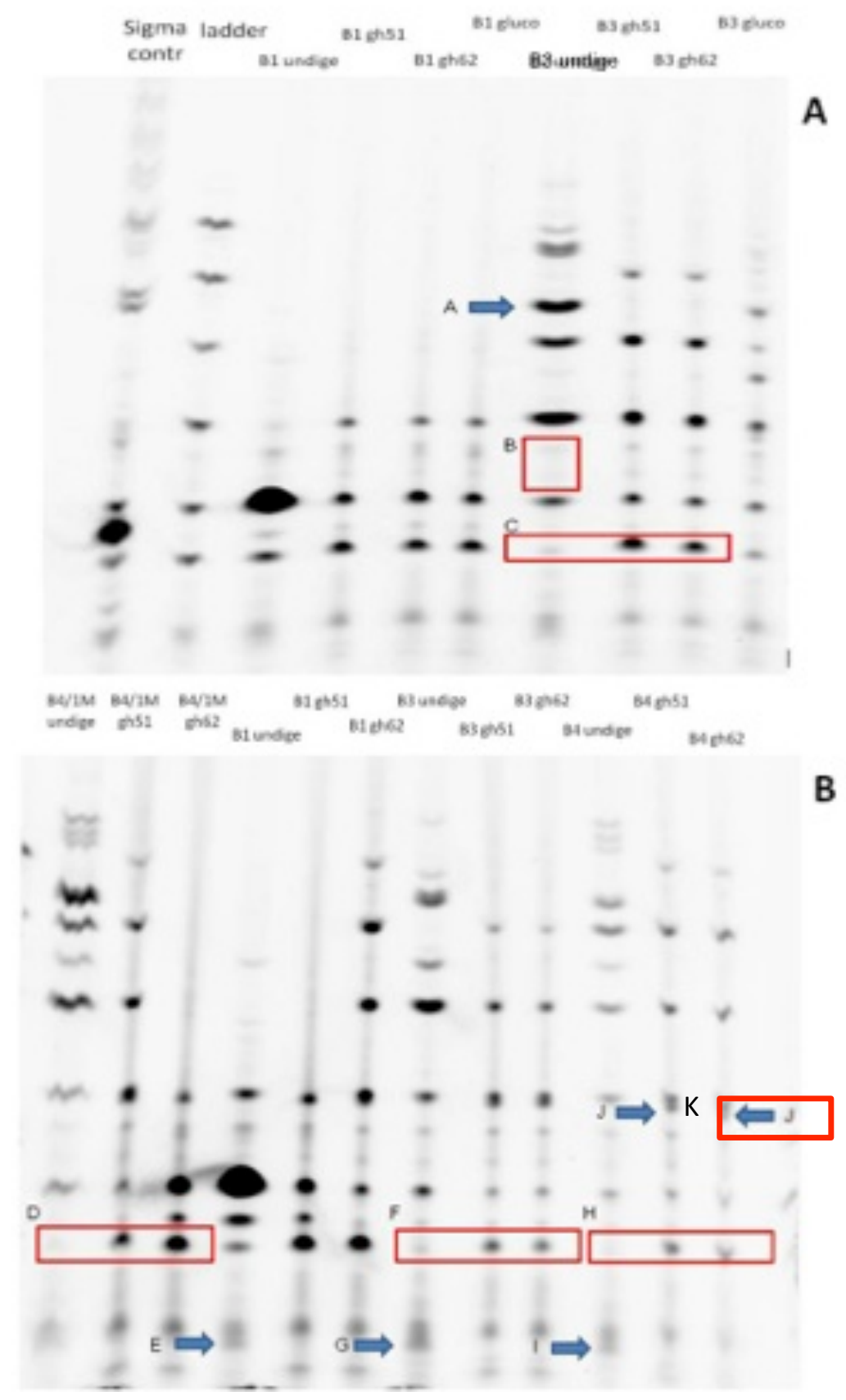

Figura 18 - Análises em PACE das bandas purificadas em TLC B1, B3 e B4 das digestões das frações $1 \mathrm{M}$ e $4 \mathrm{M}$ com Xilanase submetidas a novas digestões com 2 arabinofuranosidases (família GH51 e GH62). (A) Pace das bandas B1 e B3 purificadas em TLC, provenientes da digestão da fração $1 \mathrm{M}$ com Xilanase; (B) Pace da banda B4 purificada em TLC, proveniente da digestão da fração $1 \mathrm{M}$ com Xilanase, e das bandas B1, B3 e B4 purificadas em TLC proveniente da digestão da fração $4 \mathrm{M}$ com Xilanase. Setas (A, E, G, I): bandas presentes na fração $1 \mathrm{M}$ ou $4 \mathrm{M}$ não digerida com as arabinofuranosidases ( $\mathrm{Bx}$ undige), mas ausentes quando da presença de qualquer um das arabinofuranosidases (Bx gh51; Bx gh62); Retângulos (B, C, $D, F, H, K)$, Seta $(J)$ : bandas ausentes na fração $1 \mathrm{M}$ ou $4 \mathrm{M}$ não digerida com as arabinofuranosidases (Bx undige), mas presentes quando da presença de qualquer um das arabinofuranosidases (Bx gh51; Bx gh62). 


\section{Discussão}

\section{Estrutura fina da Parede de cana-de-açúcar: diferenças entre folha e colmo e possíveis consequências biotecnológicas. Xiloglucano, $\beta$ - glucano e arabinoxilano.}

A composição de hemiceluloses da parede celular de Monocotiledôneas Comelinóides, grupo onde se encaixa a cana-de-açúcar, é principalmente representada por arabinoxilano e $\beta$-glucano, sendo a presença de xiloglucano sempre descartada ou considerada secundária. Em 2009, Hsieh et al., demonstram a presença de xiloglucano em baixas proporções na parede celular de Gramíneas (Monocotiledôneas Comelinóides).

Como as paredes celulares possuem polímeros que interagem entre si, formando motivos arquiteturais (Buckeridge et al., 2008), é de grande importância que se conheçam as estruturas químicas destes polímeros, pois desta forma, se poderá compreender melhor suas interações e com isto manipulá-las para obter resultados tecnológicos diversos.

Os polissacarídeos apresentam uma estrutura primária, dada pelas ligações glicosídicas que o compõem. Pode-se, portanto, dizer que um determinado polissacarídeo tenha uma cadeia principal de glicoses ligadas entre si por ligações glicosídicas do tipo $\beta-1,4$. Neste caso, o polímero é a celulose. No entanto, as hemiceluloses apresentam ramificações de vários tipos em suas cadeias principais. Por exemplo, a mesma cadeia principal mencionada acima, a da celulose, pode apresentar ramificações com xilose na forma a e se ligar ao carbono 6 da glicose. Neste caso a ligação glicosídica será $a-1,6$. Neste caso o polissacarídeo ramificado é um xiloglucano. As ramificações podem ir além de um único nível e a xilose mencionada acima ainda pode ser ramificada com galactose na posição $\beta-1,2$ e esta última pode ter ainda mais uma ramificação com o monossacarídeo fucose na posição $\alpha$ 1,6. Há um outro nível de organização no polímero ao qual os estudiosos de parede celular se referem como estrutura fina. Esta determina a padrão de distribuição das diversas ramificações e confere grande complexidade a alguns polissacarídeos, como no exemplo do xiloglucano mencionado acima. 
No presente trabalho, buscou-se compreender a estrutura fina da paredes celulares de folha e colmo de cana de açúcar utilizando uma série de técnicas química, bioquímicas e físicas. Foi verificado que as paredes celulares de ambos os órgãos são do tipo II, ou seja, como hemiceluloses principalmente os arabinoxilanos, seguido de $\beta$-glucano e uma pequena proporção de xiloglucanos.

Tem sido verificada a presença de traços de manose nas análises em nosso laboratório, sendo este 1,4 ligado (Silva, 2005). No entanto, as quantidades são muito pequenas e por isto não foram o foco do presente estudo. Já os $\beta$-glucanos também não foram foco do presente estudo, uma vez que uma das teses do grupo já efetuou um estudo aprofundado dos $\beta$-glucanos de cana-de-açúcar (Silva, 2005).

Assim, o foco principal foi dado na compreensão da estrutura fina em geral de arabinoxilanos e xiloglucanos utilizando hidrólises enzimáticas e análises por HPAEC-PAD. Estas análises permitiram uma comparação entre as estruturas finas das hemiceluloses de folha e colmo da cana-de-açúcar.

As análises por HPAEC-PAD de paredes celulares (AIR) tratadas com hidrólise exaustiva com celulase, liquenase e xilanase (Figura 6) mostraram que as paredes celulares de folha parecem mais accessiveis às enzimas utilizadas do que as paredes celulares do colmo. As estruturas finas dos xiloglucanos, $\beta$-glucanos e arabinoxilanos, vistas através dos oligossacarídeos accessíveis às enzimas, também se apresentaram muito semelhantes.

No caso dos xiloglucanos e dos $\beta$-glucanos, as hidrólises enzimáticas respectivas renderam entre 1,5 e 2 vezes mais a partir de paredes celulares de folhas do que de colmo. Os arabinoxilanos se mostraram distintos, sendo que em colmo houve maior liberação de oligossacarídeos típicos de xilanos lineares (letra $D$, figura 6). Com isto, é possível que no caso da hidrólise durante o processo industrial para a produção de etanol de segunda geração, as folhas apresentem menos recalcitrância e necessitarão, provavelmente, de um prétratamento mais leve do que o bagaço de cana-de-açúcar.

Por outro lado, a matéria prima disponível para a indústria neste momento é o bagaço, que é oriundo do colmo da cana-de-açúcar. Assim, as demais análises foram efetuadas com o colmo de cana. 
No experimento em que as enzimas xilanase e liquenase, que atacam as duas principais hemiceluloses de cana-de-açúcar, utilizadas em conjunto ou separadamente em diferentes sequências relativas, observou-se que as diferenças são muito pequenas entre todos estes tratamentos. Portanto, não parece haver impedimento em usar xilanase e liquenase ao mesmo tempo na hidrólise, ou seja, não parece haver interações entre as duas enzimas, uma vez que os produtos de hidrólise são praticamente os mesmos.

\section{Xiloglucano}

O padrão relativamente simples dos perfis de oligossacarídeos de xiloglucano em HPAEC-PAD permitiram uma análise mais precisa de suas identidades.

$O$ pico $d$ da Figura 6 B pode constituir XXG, ou seja, um fragmento de xiloglucano. Em 2009, Hasieh et al. detectaram (por HPAEC-PAD e coluna Carbopac PA-100) um oligossacarídeo com tempo de retenção aproximado a 10 minutos e identificado como XXG resultante da digestão de parede de Festuca aruntinacea (gramínea) com XEG (Xyloglucan Endoglucosidase). Baseando-se na intensidade e na massas mensuradas em espectrometro, sugere-se que esse pico constitua o XXG (discutido abaixo).

Os picos a e $b$ observados nas digestões com celulase de colmo e folha de cana-de-açúcar (Figura 6 B) foram identificados como glicose e isoprimeverose, respectivamente, através da coinjeção realizada com estas substâncias (Figura 8).

A presença de glicose livre pode ser explicada através das unidades formadoras do xiloglucano em gramíneas: XXG, XXGG e XXGGG. Os oligossacarídeos XXGG e XXGGG poderiam novamente ser atacados pela atividade endo-glicosídica da celulase, originando glicose livre e G-G (celobiose).

As análises das digestões com celulase por espectrometria de massas MALDI-TOF (Figura $12 \mathrm{C}$ e D) foram preponderantes para o presente trabalho, pois complementaram na indicação da presença do xiloglucano em cana-deaçúcar e sua possível estrutura fina. 
Como proposto por Hsieh et al. (2009), o xiloglucano de monocotiledôneas interage fortemente com a celulose e somente altas concentrações de álcalis seriam capazes de separá-los, portanto, a fração da parede celular extraída com $\mathrm{NaOH} 4 \mathrm{M}$ conteria as maiores concentrações de xiloglucano.

$\mathrm{Na}$ fração $1 \mathrm{M}$, como esperado, foi baixo o nível de detecção de oligossacarídeos após digestão com celulase (Figura $12 \mathrm{C}$ ). Por si só, esse resultado pode não indicar a ausência de polissacarídeos digeríveis por celulase (por exemplo, xiloglucano) na fração $1 \mathrm{M}$, porém sugere que 0 substrato para a celulase não é abundante.

Por sua vez, a fração 4M após digestão com celulase apresentou 3 picos preponderantes (indicados por retângulos na figura $12 \mathrm{D}$ ). As massas 701-1115 podem corresponder à massas de duas pentoses e 3 hexoses com acréscimo de uma hexose (162) ou uma pentose (132) a cada degrau.

Esse fato, somado à comparação com a publicação de Hsieh et al. (2009), sugere serem essas as massas correspondentes a oligossacarídeos de xiloglucano típico de gramíneas. A espectrometria de massas dos oligossacarídeos da fração $4 \mathrm{M}$ digerida com celulase detectou os oligossacarídeos XXG, XXGG, XXGGG/XLGG. Neste último caso a estrutura é dúbia, pois as ramificações com galactose $-L$ - possuem a mesma massa da glucose (Figura $12 \mathrm{D}$ ).

Além destes oligossacarídeos ainda são detectadas massas correspondentes ao XXXG (1085), XLXG/XXLG (1247) e XXXXG (1379), fragmentos estes correspondentes a xiloglucanos encontrados em concentrações apreciáveis em eudicotiledôneas (Figura 12 D).

O último fragmento, o XXXXG, somente havia sido encontrado após a digestão de xiloglucano de reserva de Hymenea courbaril, jatobá, (Tiné et al., 2003), revelando-se dessa forma, o segundo relato deste tipo de oligossacarídeo.

Pode-se sugerir, após esse experimento, que a estrutura fina do xiloglucano de cana consiste de um polímero composto principalmente por oligossacarídeos XXG, XXGG e XXGGG/XLGG. Em menores proporções, e com finalidade ou posição desconhecidas, temos oligossacarídeos menos abundantes, caso do XXXG, XLXG/XXLG e XXXXG. 
Sobre os xiloglucanos de cana-de-açúcar, portanto, os dados sugerem que há dois tipos, um característico de gramíneas e outro de eudicotiledôneas, sendo este último menos abundante. Com os dados obtidos, não é possível saber se estes dois padrões de estrutura fina pertencem às mesmas moléculas ou se há dois xiloglucanos distintos. Serão necessários estudos topológicos, utilizando anticorpos que reconheçam especificamente cada uma das estruturas finas poderão esclarecer melhor como os xiloglucanos se distribuem nas células do colmo.

Considerando os rendimentos dos fracionamentos, bem como das digestões com xilanase, que precederam a digestão com endo-celulase, a proporção desse polissacarídeo é de $3 \%$ da massa total de hemiceluloses. Por outro lado, ainda que o xiloglucano seja uma hemicelulose menos abundante, a sua importância pode ser grande, uma vez que é um polímero que conhecidamente interfere nas características do domínio celulose-hemicelulose da parede celular.

No que concerne aos processos de hidrólise em ambiente industrial, ainda que o xiloglucano não possa ser considerado como uma contribuição quantitativa direta para a produção de etanol de cana-de-açúcar, a compreensão de sua estrutura fina pode ter um impacto no processo de hidrólise, uma vez que se conheça melhor o seu papel no arranjo de polímeros nas paredes celulares de colmo.

\section{$\beta$-glucano}

No que se refere ao $\beta$-glucano, a proporção entre trissacarídeos e tetrassacarídeos obtida após as digestões com liquenase em folhas e colmo de cana-de-açúcar é de 2:1 (Figura $6 \mathrm{C}$ ), como esperado para gramíneas (Buckeridge et al., 2004) evidenciando que a estrutura do polissacarídeo de $\beta$ glucano encontrado em ambos os órgãos é a mesma. De fato, estes resultados confirmam um estudo sobre $\beta$-glucanos que foi efetuado pelo nosso grupo (Silva, 2005), que mostrou que a proporção entre tri e tetrassacarídeos não varia substancialmente de tecido para tecido em cana-de-açúcar.

Aparentemente a digestão do $\beta$-glucano da folha gerou uma maior intensidade de sinal, o que pode indicar uma maior concentração desse 
polissacarídeo em folha ou uma maior acessibilidade da enzima ao seu substrato, gerando mais fragmentos do que em colmo, onde o $\beta$-glucano estaria menos acessível.

Os experimentos com digestões sequenciais de paredes celulares (AIR) de colmo mostraram que os $\beta$-glucanos parecem não interferir no acesso de hidrolases à parede celular, especificamente a xilanase, que ataca a principal hemicelulose de cana-de-açúcar, o arabinoxilano.

\section{Arabinoxilanos}

As digestões de colmo e folha com xilanase geraram fragmentos típicos de uma série de xilano (Kormelink et a.l, 1993) (Figura 6 D). Aparentemente não há muitas ramificações nos polissacarídeos clivados, uma vez que, a endoxilanase clivaria justamente após uma ramificação com arabinose. Corroborando este dado, o perfil de monossacarídeos neutros oriundos da parede celular de folha e colmo indica baixas concentrações de arabinose, sugerindo que o polissacarídeo seja pouco ramificado (de Souza, 2007, Sousa, 2011).

Além disso, dois picos foram detectados em colmo e não estão presentes em folha nos mesmos níveis (Figura $6 \mathrm{D}$, indicados pelo h-i). Como os tempos de retenção dos picos estão entre 10 e 12 minutos em HPAEC, a presença destes dois fragmentos pode indicar que o arabinoxilano de colmo seria menos ramificado, pois gerou mais pontos de clivagem para a ação da xilanase sobre porções de xilano linear.

Da mesma forma que as digestões com celulase e liquenase, a digestão com xilanase em folha de cana-de-açúcar parece mais eficaz pela presença de picos de alta intensidade, sugerindo novamente, uma maior acessibilidade à parede celular de folha do que de colmo.

Esta evidência pode significar que a parede celular de colmo de canade-açúcar seja mais compacta quando comparada a parede celular de folha, ou seja, a primeira teria uma maior interação entre os polissacarídeos hemicelulósicos, o que seria esperado visto a função de sustentação deste órgão. Isto poderia estar relacionado ao fato de que o tecido de colmo possui 
maior proporção de tecido vascular e que os xilanos lineares estariam mais relacionados às fibras do tecido vascular.

Com a finalidade de compreender a estrutura fina dos arabinoxilanos presentes em colmo de cana-de-açúcar, foi utilizada uma estratégia de uso de técnicas combinadas de análises por TLC e HPAEC para acesso ao padrão de ramificação dos polímeros. As análises por estas duas técnicas, quando associadas aos resultados de espectrometria de massas, permitiu identificar alguns oligossacarídeos chave para entender a estrutura fina do arabinoxilano de colmo.

As massas mensuradas após a digestão com xilanase das frações $1 \mathrm{M} \mathrm{e}$ $4 \mathrm{M}$, demonstram a presença de uma escada de massas variando de 701 a 1889 (sucessivas somas de 132) (Tabela 3; Figura 12 A e B). Considerando o peso de um aduto de sódio 23, a presença de uma molécula de água 18 e o peso de cada pentose 132, consegue-se determinar que o valor 701 corresponde ao peso de uma molécula de 5 pentoses. É importante lembrar que o valor de massa da arabinose e xilose são as mesmas, pois ambas são pentoses.

Dessa forma, considerando a espectrometria de massas da fração $1 \mathrm{M}$ digerida com xilanase (Figura $12 \mathrm{~A}$ ), os valores de massa encontrados, de 7011889, temos uma escada composta por número crescente de pentoses variando de 5 a 14 resíduos. Analisando as possibilidades para caracterizar a molécula de 5 pentoses, temos: 5 xiloses e/ou 4 xiloses e 1 arabinose e/ou 3 xiloses 2 arabinoses, portanto, pode ser oriunda da digestão de um xilano puro ou de um arabinoxilano com crescente grau de ramificação com arabinoses. A mesma regra é aplicável aos resíduos de peso maior, com suas respectivas combinações.

Ressalta-se que uma mistura ainda é possível, ou seja, tanto xilanos quanto arabinoxilanos podem estar presentes, e as massas mensuradas decorrerem da digestão de diferentes polissacarídeos, mas que geram fragmentos de massas iguais. Nesse caso, a única forma de determinar a exata proporção e presença das isoformas, seria purificar em HPLC cada um dos picos (Figura 14 e 15) e refragmentá-las (MALDI-TOF-TOF), porém, devido ao tempo limitado em Cambridge, não foi possível realizar tais técnicas. Outra opção seria acoplar um espectrômetro de massas ao sistema Dionex de 
HPAEC, de forma que cada pico na Figura 11 pudesse ser identificado diretamente.

Os mesmos valores de massa foram detectados na digestão do polissacarídeo da fração 4M digerida com xilanase (Figura $12 \mathrm{~B}$ ). Entretanto, o número de resíduos de pentose variou de 5 a 8 , dentro da faixa de detecção do equipamento.

Nas figuras 16 e 17, resultados do PACE para as bandas isoladas por TLC das frações $1 \mathrm{M}$ e 4M digeridas com xilanase (Figura 16 e 17), percebemse bandas nas amostras que coincidem com os padrões de oligossacarídeos de xilose (1-6 resíduos), demonstrando a presença de oligossacarídeos de xilose não-ramificados no material analisado, sendo este resultado esperado, uma vez que, o material original deveria conter polissacarídeos compostos por xilose, pois arabinoxilanos e xilanos estão presentes em cana-de-açúcar (Buckeridge et al., 2011).

Além disso, nas Figuras 18 nota-se que quanto mais alta a banda na placa de TLC (sendo a B1 a mais alta e a B8 a mais baixa), maior a frequência de oligossacarídeos de baixo peso molecular (1, 2 e 3 resíduos), e à medida que se analisam as bandas inferiores isoladas do TLC (B4 a B8), maior as frequências de oligossacarídeos maiores (4, 5 e 6 resíduos).

$\mathrm{Na}$ tentativa de unir os resultados de espectrometria de massas aos resultados do PACE e HPAEC, procedeu-se com a identificação das massas das Bandas 1 a 3 das frações $1 \mathrm{M}$ e $4 \mathrm{M}$.

Em uma análise inicial, supôs-se que a escada de massas apresentada pelo MALDI-TOF (Figura 12 A e B indicação por retângulos e setas) poderia se tratar dos oligossacarídeos presentes nas Bandas 1-3.

Entretanto, ao submeter uma alíquota de enzima Xilanase de Thermomyces lanuginosus (Sigma®) (controle negativo) à uma corrida em PACE, como pode ser visto na Figura 16 e 17 - primeira raia (Sigma contr), nota-se a presença de bandas contaminantes. Sendo assim, algumas das bandas percebidas no PACE da digestão $1 \mathrm{M}$ e $4 \mathrm{M}$ com xilanase, ou ainda, no MALDI-TOF destas mesmas digestões (Figura 16 e 17 A e B), constitui uma contaminação da enzima utilizada.

A análise individual do PACE das bandas isoladas por TLC da fração 4M digerida com xilanase (Figura 13) sugere que na fração com maior força iônica 
(fração 4M) existe maior quantidade de xilanos sem ramificação, devido a apresentação em grandes quantidades de oligossacarídeos de xilano compostos por poucos resíduos de xilose (2-3) e pequenas quantidades de oligossacarídeos de arabinoxilano por quantidades intermediárias de resíduo de xilose (3-6).

A quantidade elevada de oligossacarídeos de baixo peso molecular (2-3 resíduos de xilose) indica que a ação enzimática não foi dificultada pela presença de ramificações possibilitando que o polissacarídeo fosse digerido a seus oligossacarídeos mínimos.

Após as análises do PACE das bandas isoladas por TLC das digestões das frações $1 \mathrm{M}$ e $4 \mathrm{M}$, as bandas 1, 3 e 4 "purificadas", de ambas as frações foram submetidas a digestões com arabinofuranosidases da família GH51 e GH62. Com estas digestões esperava-se observar a mudança no padrão dos oligossacarídeos digeridos com estas enzimas, o que seria um indicativo da presença de ramificações com arabinose e, portanto, presença de arabinoxilanos.

As bandas 1, 3 e 4 foram as escolhidas, pois continham uma menor quantidade dos oligossacarídeos provenientes da enzima Xilanase (Sigma ${ }^{\circledR}$ ) quando comparado as demais bandas. A banda 2 não foi incluída na análise, pois, havia sido utilizada para ensaios de permetilação (dados não mostrados neste relatório).

As digestões com arabinofuranosidase da bandas 1, 3 e 4 isoladas por TLC da fração 1M com enzimas da família GH51 e GH62 (Figura 18 A e B), demonstram a presença exclusiva de xilanos na Banda 1, pela ausência de modificações no padrão de oligossacarídeos do controle (não digerido com arabinofuranosidases) (B1 undige) e das alíquotas digeridas por estas enzimas (B1 gh51 e B1 gh62).

Por outro lado, nas Bandas 3 e 4 (Fração 1 M) (Figura 18 A e B) sugerese a presença de arabinoxilanos, pois nas amostras não digeridas com arabinofuranosidases ( $B 3$ undige e $B 4$ undige) existem bandas (indicada pela seta e letra $A$ na Banda 3 ) que desaparecem após a ação das arabinofuranosidases (Figura 18 A e B: B3 gh51 e B3 gh62 - seta e letra A; B4 gh51 e $B 4$ gh62 - retângulo D) e dão origem a novas bandas presentes 
somente nas amostras digeridas com as arabinofuranosidases (Figura $18 \mathrm{~A} \mathrm{e}$ B: B3 gh51 e B3 gh62 - retângulo B e C; B4 gh51 e B4 gh62 - retângulo D).

As digestões com arabinofuranosidase da bandas 1, 3 e 4 "purificadas" da fração 4M com enzimas da família GH51 e GH62 (Figura 18 B), demonstram a presença de xilanos e arabinoxilanos na Banda 1, pela ausência de modificações no padrão de oligossacarídeos do controle (não digerido com arabinofuranosidases) (B1 undige) e das alíquotas digeridas por estas enzimas (Figura 18 B: B1 gh51 e B1 gh62), com exceção do desaparecimento da banda (indicada pela seta e letra $E$ ) quando da ação das arabinofuranosidases (Figura 18 B: B1 gh51 e B1 gh62).

Da mesma maneira que nas Pistas 3 e 4 da fração $1 \mathrm{M}$, nas Pistas 3 e 4 da fração 4M (Figura 18 B) sugerem a presença de arabinoxilanos, pois nas amostras não digeridas com arabinofuranosidases (B3 undige e B4 undige) existem bandas (indicada pela seta e letra $G$ na Banda 3; indicada pela seta e letra I na Banda 4 - Figura 18 B) que desaparecem após a ação das arabinofuranosidases e dão origem a novas bandas presentes somente nas amostras digeridas com as arabinofuranosidases (Figura 18 B: B3 gh51 e B3 gh62 - retângulo F; B4 gh51 e B4 gh62 - retângulo D e seta e letra J).

Apesar da ocorrência de arabinoxilanos na fração 4M, nota-se que a intensidade das bandas que desaparecem nas amostras não digeridas com as arabinofuranosidases e as novas bandas que aparecem nas amostras digeridas com estas enzimas são fracas, quando comparadas à fração $1 \mathrm{M}$ (Figura $18 \mathrm{~A}$ e B).

Dessa forma, evidencia-se que em ambas as frações existem evidências da presença de porções ramificadas (arabinoxilanos) e lineares (xilanos), bandas estas que não se modificam com a ação das arabinofuranosidases. No entanto, os porções mais ramificadas (de arabinoxilanos) estão presentes em proporções maiores na fração $1 \mathrm{M}$, enquanto porções lineares (xilanos) estão em maior proporção na fração 4M.

Em conjunto, os resultados das análises por PACE (com e sem tratamento com arabinofuranosidases) e HPLC dos hidrolisados das frações 1 e 4M com xilanase e também as análises por espectrometria de massas MALDI-TOF sugerem que os arabinoxilanos de colmo de cana-de-açúcar são compostos por sequências lineares que variam entre 2 e 14 unidades de xilose 
e paralelamente, há porções, ou polissacarídeos separados, que são compatíveis com arabinoxilanos que têm como principais motivos estruturais quatro xiloses e uma arabinose $\left(X_{4} A\right)$ e cinco xiloses e uma arabinose $\left(X_{5} A\right)$. Considerando que endo- $\beta$-xilanases hidrolisam arabinoxilanos quebrando uma ligação $\beta-1,4$ ao lado de uma ramificação com arabinose, a maior probabilidade é que o polímero tenha porções com a estrutura mostrada na Figura 4.

No entanto, maiores detalhes podem ser extraídos das análises de PACE e com isto uma série de hipóteses sobre a estrutura fina dos arabinoxilanos podem ser propostas.

Observando a Figura 18, além dos oligossacarídeos compostos somente por xilose $\left(X_{2}\right.$ até $\left.X_{5}\right)$, há duas bandas fortes em PACE que são intermediárias entre $\mathrm{X}_{4}$ e $\mathrm{X}_{5}$, possivelmente composta de 5 pentoses (xiloses e arabinoses) e outra intermediária entre $\mathrm{X}_{5}$ e $\mathrm{X}_{6}$, possivelmente composta de 6 pentoses (xiloses e arabinoses).

Uma vez que a digestão da banda B3 de TLC (fração $1 \mathrm{M}$ ) com arabinofuranosidases (Figura $18 \mathrm{~A}$ ) gerou uma banda equivalente a monossacarídeos (arabinose) e proporções similares de $\mathrm{X}_{2}, \mathrm{X}_{3}$ e $\mathrm{X}_{4}$, pode-se sugerir possíveis estruturas para os motivos arabinosilados de xilano de colmo de cana-de-açúcar.

Estas proporções são compatíveis com a formação, a partir da banda A (que deve ser composta por 5 pentoses pelo seu tempo de retenção) dos fragmentos $X_{2} A_{3}, X_{3} A_{2}$ e $X_{4} A$, novamente lembrando que esta hipótese considera que a xilanase utilizada reconhece 0 polímero através das ramificações com arabinose, como nossos dados parecem sugerir.

Assim, as possíveis estruturas presentes na banda B3 seriam:<smiles></smiles>

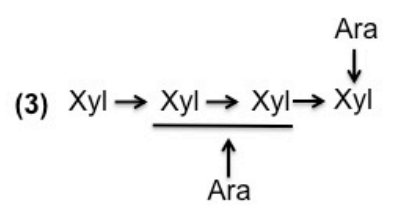


Sendo Xyl=xilose, Ara=arabinose e o grifo na estrutura (3) indicando que a arabinose pode ramificar a segunda ou a terceira xilose. $O$ final redutor da molécula está a direita neste modelo.

Estas estruturas em conjunto, quando submetidas à hidrólise com arabinofuranosidases $\mathrm{GH} 51$ ou GH62 produziriam uma mistura equimolar de X2, X3 e X4 e arabinose livre, que é que se observa na Figura 18 A para a análise da banda B3.

Já a banda B4 da fração 1M (Figura 18 B) gerou um padrão análogo ao da banda B3 quando submetido à hidrólise com arabinofuranosidases GH51, mas com predominância dos oligossacarídeos de xilose X3, X4 e X5. Como a banda intermediária entre os oligossacarídeos de xilanos lineares na banda B4 da fração $1 \mathrm{M}$ é o intermediário entre $\mathrm{X} 5$ e X6, sendo portanto no máximo uma xilopentaose ramificada com uma arabinose, a estrutura fina da banda B4 teria estrutura fina muito próxima à da banda B3, sendo hipoteticamente:

Ara
(1) $\mathrm{Xyl} \rightarrow \mathrm{Xyl} \rightarrow \mathrm{X}^{\downarrow} \mathrm{yl}^{\downarrow}$
Ara Aैra

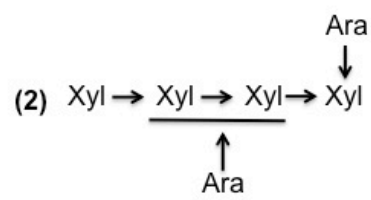

(3) $\mathrm{xyl} \rightarrow \mathrm{xyl} \rightarrow \mathrm{xyl} \rightarrow \mathrm{xyl} \rightarrow \mathrm{xyl}$

Sendo $\mathrm{Xyl}=x \mathrm{ilose}$, Ara=arabinose. $\mathrm{O}$ final redutor da molécula está a direita neste modelo.

Não é possível, com estes dados, saber quais as sequências existentes destes polissacarídeos. Uma perspectiva de grande importância é que para avançar o conhecimento sobre os padrões de ramificação do arabinoxilano $1 \mathrm{M}$ de colmo de cana-de-açúcar, os oligossacarídeos arabinosilados deverão ser estudados mais a fundo. 
Para tanto, uma análise ainda mais precisa dos oligossacarídeos, com subsequentes análise por espectrometria de massas nos moldes utilizados por Tiné et al. (2006). Estudos mais aprofundados sobre o modo de ação da GH51 e GH62 também poderiam trazer informações valiosas sobre as posições das arabinoses nos oligossacarídeos arabinosilados do arabinoxilano da fração $1 \mathrm{M}$.

No caso da análise da fração $4 \mathrm{M}$ por TLC-PACE, foi observado um comportamento similar das bandas arabinosiladas observadas para a fração $1 \mathrm{M}$, com estas sendo atacadas pelas arabinofuranosidases e gerando arabinose livre e série homóloga de xilano. No entanto, no caso da análise da banda 4 da fração $4 \mathrm{M}$ observou-se o aparecimento de uma banda logo abaixo da $X_{3}$ após o tratamento com GH51 e GH62, o que denota uma estrutura intermediária que poderia ser um dissacarídeo de xilose ramificado com ácido glucurônico. Estas bandas também terão que ser isoladas e estudadas mais a fundo.

É importante salientar, ainda, que a resolução geral da combinação de técnicas utilizadas neste trabalho permitiu observar estruturas relacionadas às ramificações existentes em oligossacarídeos com até 5 xiloses na cadeia principal. No entanto, há uma série de outros oligossacarídeos, que podem ser detectados em HPAEC-PAD (Figura 11), mas por estarem em menor proporção, não puderam ser analisados em detalhe.

As análises acima permitem formular hipóteses sobre os padrões de ramificação dos arabinoxilanos de colmo com arabinose. Como nesta parte do trabalho (TLC-PACE) não foi feito um balanço de massas preciso sobre as porções atacadas e não atacadas pela endo- $\beta$-xilanase, pouco pode-se inferir sobre o grau de ramificação dos polímeros.

Por outro lado, os dados de HPAEC-PAD podem ser utilizados para uma análise geral dos arabinoxilanos de cana-de-açúcar. Pelo que é mostrado na Figura $11 \mathrm{~A}$ e $11 \mathrm{~B}$ as hidrólises exaustivas com endo- $\beta$-xilanase geram oligossacarídeos-limite que apresentam oligossacarídeos de xilanos lineares (picos entre 5 e $13 \mathrm{~min}$ ) cerca de duas vezes maior do que os ramificados (picos entre 13 e $20 \mathrm{~min}$ ). Deve-se salientar ainda que nos dois casos (frações $1 \mathrm{M}$ e $4 \mathrm{M}$ ) a hidrólise com xilanase foi de carca de $85 \%$ da massa inicial. Portanto, é plausível supor que aproximadamente $30 \%$ do arabinoxilano de 
colmo de cana-de-açúcar seja do tipo ramificado, com variações principalmente no grau e padrão de arabinosilação.

Uma conclusão importante que pode ser tirada das análises como um todo é que as ramificações parecem ter um papel crucial no processo de hidrólise com xilanase, uma vez que a família de oligossacarídeos ramificados com arabinose não foi accessível à endo- $\beta$-xilanase quando as paredes de colmo e de folhas estavam intactas (AIR). Como as moléculas de arabinose são consideradas as bases para a esterificação do arabinoxilano com ácidos ferúlicos, que formam diferúlicos e mantêm os polímeros ligados entre si, é possível que esta tenha, de fato, sido a limitação para a ação da endo- $\beta$ xilanase às paredes não tratadas com $\mathrm{NaOH}$, o qual é conhecido por quebrar as ligações ésteres entre carboidratos e compostos fenólicos e deve ter alterado a composição do arabinoxilano durante o processo de fracionamento.

Estas descobertas têm implicações importantes para o processo de hidrólise enzimática que deverá ser utilizado para a produção etanol de segunda geração a partir de cana-de-açúcar. Nossas descobertas explicam porque os pré-tratamentos com álcali aumentam o acesso das enzimas aos polissacarídeos de parede.

Portanto, os dados produzidos neste trabalho sobre a estrutura fina dos arabinoxilanos de cana fornecem bases científicas importantes que poderão, no futuro, serem adaptadas para o bagaço e, assim, ajudarem a melhorar o processo de produção de etanol de segunda geração no Brasil.

\section{Interações entre hemiceluloses e a limitações para hidrólise enzimática}

Ainda que o isolamento de polissacarídeos e os estudos aprofundados sobre as suas estruturas sejam importantes para compreender o processo de hidrólise, estudos com paredes integras (AIR) são fundamentais para se compreender como tais materiais se comportarão em um processo industrial. Isto porque as paredes integras (i.e. sem fracionamento) preservam ramificações como acetil e fenólicos que podem ter sido retiradas durante o fracionamento e assim modificado consideravelmente o acesso das enzimas aos polissacaraídeos hemicelulósicos. 
Por este motivo foram realizados experimentos com a finalidade de verificar a liberação de oligossacarídeos a partir de paredes integras (AIR) de forma que se pudesse comparar os acessos de enzimas a polissacarídeos hemicelulósicos em suas formas isoladas contendo somente (ou predominantemente) carboidratos e na forma encontrada na parede celular, ou seja formando compósitos em que os polímeros estão em interação entre si.

As interações entre os polissacarídeos de parede celular podem ser não covalentes e covalentes (Buckeridge et al., 2008). No primeiro caso, as cadeias principais interagem entre si por ligações de pontes de hidrogênio. No segundo, compostos fenólicos covalentemente ligados às ramificações podem formar ligações covalentes entre si e intertravar o compósito que forma a parede celular (Buonafina, 2009). Além disto, já foi demonstrado que em gramíneas, os anéis diferúlicos inibem a degradação da parede celular por enzimas (Grabber et al., 1998).

Neste trabalho, estudou-se indiretamente a importância destes fatores sobre a hidrólise enzimática através de avaliações da acessibilidade das enzimas liquenase e xilanase à parede celular de colmo de cana-de-açúcar.

A celulase não tem acesso ao arabinoxilano quando as paredes estão íntegras, mas passa a ter quando as frações são produzidas com o uso de $\mathrm{NaOH}$, que tem a capacidade de desesterificar os arabinoxilanos. No caso do colmo, houve alguma liberação de oligossacarídeos de xilanos lineares, mas muito pouco ou nada no caso da folha.

Tal observação permite hipotetizar que além da presença dos diferulatos, os xiloglucanos também podem estar em interação com arabinoxilanos na parede íntegra, interação esta que desaparece durante o fracionamento. Tal interação é desconhecida, não sendo possível encontrar literatura que tenha reportado interações entre estes dois polímeros. As interações possíveis seriam através de ligações por pontes de hidrogênio ou por compostos fenólicos (diferulatos) entre os resíduos de arabinose que ramificam o arabinoxilano e os de galactose que ramificam o xiloglucano.

Pode-se especular, portanto, que a interação com os xiloglucanos explique em parte a razão pela qual as regiões ramificadas dos arabinoxilanos não são accessíveis à endo- $\beta$-xilanase, mas esta hipótese requer uma série de experimentos para ser comprovada. 
No entanto, um problema com esta hipótese é que, sendo somente $3 \%$ da parede celular os xiloglucanos não poderiam explicar a supressão da produção oligossacarídeos de toda a porção arabinosilada do arabinoxilano, polímero este que corresponde a quase $20 \%$ da parede, dados os balanços de massas das digestões, e que tem $33 \%$ (ou seja $6,6 \%$ das moléculas de arabinoxilanos) ramificados com arabinose. Além disto, a formação de diferulatos requer ramificações do xiloglucano com galactose e no caso do xiloglucano de cana-de-açúcar estas ramificações são raras. De fato, como descrito neste trabalho, os xiloglucanos encontrados em cana-de-açúcar, constituem, na realidade, cadeias de $\beta$-glucano similares à celulose, com ramificações esparsas com xilose o que lhe confere a propriedade de interagir com cadeias de xilano.

Em resumo, serão necessários mais experimentos com xiloglucanos e arabinoxilanos de cana-de-açúcar, isolados ou em parede integra, para avaliar se estes dois polímeros estariam envolvidos em um processo de interação que influencia a degradação enzimática da parede da cana-de-açúcar.

Aventou-se também a possibilidade de que os $\beta$-glucanos poderiam exercer este papel, uma vez que se apresentam em uma proporção na parede mais próxima à proporção de arabinosilação dos xilanos no colmo de cana-deaçúcar.

Em experimentos em que liquenase e xilanase foram adicionados a paredes integras tanto sequencialmente como em paralelo, verificamos que não há interferência da presença de um polímero hemicelulósico ( $\beta$-glucano) em relação ao outro (arabinoxilano). Não houve, por exemplo, alterações na exposição das ramificações do arabinoxilano, o que seria uma predição da hipóteses de que ambos estariam ligados entre si limitando o acesso às enzimas.

Em resumo, houve pequenas modificações quando as diversas combinações entre xilanase e liquenase foram feitas. Porém, nenhuma destas modificações parece estar associada com algo mais profundo com uma interação intermolecular entre $\beta$-glucano e arabinoxilano nos moldes do que foi discutido acima em relação ao xiloglucano. 


\section{Considerações Finais}

O presente trabalho trás informações novas a respeito da estrutura fina das hemiceluloses de cana-de-açúcar, que não eram conhecidas para esta planta até o momento.

As três principais classes de polímeros são os arabinoxilanos, os $\beta$ glucanos e os xiloglucanos, em ordem decrescente de grandeza nas paredes de folha e de colmo de cana-de-açúcar.

A análise da estrutura fina utilizando celulase levou à caracterização de um xiloglucano na fração $4 \mathrm{M}$, provavelmente interagindo com celulose ou com arabinoxilano. A estrutura fina do xiloglucano de cana é típica das gramíneas, segundo Hiasieh et al. (2009) sendo composto principalmente dos oligossacarídeos: XXG, XXGG, XXGGG/XLGG; mas ainda apresentado os oligossacarídeos: XXXG, XLXG/XXLG e XXXXG.

Os $\beta$-glucanos são aqueles típicos de gramíneas, com uma relação entre tri e tetrassacarídeo de 2:1, indicando que a estrutura fina deste polímero é bastante similar aos encontrados em parede celular de milho, trigo, aveia entre outros.

A principal hemicelulose de cana-de-açúcar é o arabinoxilano, e a análise de sua estrutura fina usando hidrólise com endo- $\beta$-xilanase mostrou que esta hemicelulose é composta por sequências de xilanos lineares e xilanos ramificados com arabinose em um padrão em que há pelo menos uma arabinose a cada 4 ou 5 xiloses na cadeia principal. Há variações, sendo possível encontrar porções mais ramificadas com arabinose. A única evidência da presença de ácidos glucurônicos no arabinoxilano foi obtida após hidrólise de uma mistura de oligossacarídeos com glucuronidase. Porém a presença deste tipo de ramificação parece ser bem rara em cana-de-açúcar.

Hidrólises enzimáticas de paredes íntegras do colmo de cana-de-açúcar tanto sequencialmente como em paralelo, revelaram que os arabinoxilanos são menos acessíveis à endo- $\beta$ - xilanase, mas se tornam mais susceptíveis a digestão após o fracionamento com álcali. 
O tratamento com celulase parece ter liberado alguns oligossacarídeos arabinosilados do arabinoxilano, sugerindo que os xiloglucanos possam exercer um papel na resistência dos arabinoxilanos ramificados à hidrólise.

$\mathrm{O}$ fato do tratamento com álcali ter liberado o acesso ao arabinoxilano ramificado pela endo- $\beta$-xilanase sugere fortemente que na parede integra as arabinoses se ligam através de pontes diferúlicas, prevenindo 0 ataque enzimático. O papel do xiloglucano na resistência a hidrólise pode estar envolvido, mas este aspecto terá que ser estudado mais a fundo no futuro.

As conclusões tiradas neste trabalho sobre as estruturas das principais hemiceluloses de cana-de-açúcar e de como os polímeros podem ou não estarem interagindo na parede integra apresentam-se como informações estratégicas para o desenho de futuros processos para a produção de etanol de segunda geração no Brasil, uma vez que a cana-de-açúcar será a principal fonte de matéria prima a ser usada quando estes processos estiverem estabelecidos na indústria.

Além disso, o trabalho trás informações relevantes acerca dos efeitos dos álcalis na parede celular de cana, e o seu efeito na digestibilidade do material. Os dados de estrutura fina e de interação entre os polímeros, sugerem motivos arquitetônicos na parede celular, que podem ser os responsáveis pelo travamento do sistema. 


\section{Bibliografia}

BUCKERIDGE, M. S. 2008. Rotas para o etanol celulósico em um cenário de mudanças climáticas. Opiniões (Rib. Preto), 20: 62 - 64 .

BUCKERIDGE, M. S.; CAVALARI, A. A.; SILVA, G. B. DA. 2008. Parede Celular. In: Gilberto Barbante Kerbauy. (Org.). Fisiologia Vegetal. Rio de Janeiro: Guanabara Koogan, pg 165-181.

BUCKERIDGE, M.S. \& DIETRICH, S.M.C. 1996. Mobilisation of the raffinose family oligosaccharides and galactomannan in germinating seeds of Sesbania marginata Benth. (Leguminosae-Faboideae). Plant Science 117:33-43.

BUCKERIDGE, M.S., SANTOS, H.P. \& TINÉ, M.A.S. 2000. Mobilisation of storage cell wall polysaccharides in seeds. Plant Physiology \& Biochemistry. 38: 141-156. 
BUCKERIDGE M.S., DE SOUZA,A.P., ARUNDALE, R.A., ANDERSONTEIXEIRA K.J., DELUCIA, E. 2011 Ethanol from Sugarcane in Brazil: A "Midway" Strategy for Increasing Ethanol Production while Maximizing Environmental Benefits. Global Change Biology Bioenergy (doi: 10.1111/j.17571707.2011.01122.x)

BUONAFINA, M.M.O. 2009. Feruloylation in grasses: current and future perspectives. Molecular Plant 2: 861-872

DE SOUZA, A. P. 2007. A cana-de-açúcar e as mudanças climáticas: efeitos de uma atmosfera enriquecida em $\mathrm{Co} 2$ sobre o crescimento, desenvolvimento e metabolismo de carboidratos de Saccharum ssp. Dissertação (Mestrado em Biologia Celular) - Universidade Estadual de Campinas.

GOUBET F.; JACKSON P.; DEERY, M. J.; DUPREE P.. 2002. Polysaccharide Analysis Using Carbohydrate Gel Electrophoresis: A Method to Study Plant Cell Wall Polysaccharides and Polysaccharide Hydrolases, Analytical Biochemistry, Volume 30, Pages 53-68

CARPITA, N. \& MCCANN, M. 2000. The cell wall. In: B.B. Buchanan, W. Gruissem and R.L. Jones (Eds.), Biochemistry and Molecular Biology of Plants, American Society of Plant Physiologists, Rockville, MD, pp. 52-108.

CARPITA, N.C. 1996. The structure and biogenesis of the cell walls of grasses. Annu Rev Plant Physiol Plant Mol Biol 47: 445-476.

CAVALARI, A. A. 2009. Modificações da parede celular de frutos do mamoeiro (Carica Papaya). 2009. Tese (Doutorado em Biologia Vegetal) Universidade Estadual de Campinas.

COSGROVE, D.J. 1999. Expansive growth of plant cell walls. Plant Physiol. Biochem., 38 (1/2), 109-124. 
FRY, S. C.; YORK, W. S.; ALBERSHEIM, P.; DARVILL, A.; HAYASHI, T.; JOSELEAU, J-P; KATO, Y.; LORENCES, E. P.; MACLACHLAN, G. A.; MCNEIL, M.; MORT, A. J.; REID, J. S. G.; SEITZ, H. U.; SELVENDRAN, R. R.; WHITE, A. L. 1993. An unambiguous nomenclature for xyloglucanderived oligosaccharides. Physiologia Plantarum 89: 1-3.

GORSHKOVA T. A.; WYATT S. E.; SALNIKOV V. V.; GIBEAUT D. M.; IBRAGIMOV M. R.; LOZOVAYA V. V.; CARPITA N. C. 1996. Cell-Wall Polysaccharides of Developing Flax Plants. Plant Physiol. 110: 721-729.

GRABBER, J.H., HATFIELD, R.D. AND RAOLPH, J. 1997. Diferulate crosslinks impede the enzymatic degradation of non-lignified maize walls

GROHMANN, K.; MITCHELL, D.J.; HIMMEL, ME.; DALE, B.E.; SHROEDER, H.A. 1989. The role of ester groups in resistance of plant cell wall polysaccharides to enzymatic hydrolysis. Applied Biochemistry and Biotechnology. 20/21:45-61.

HAYASHI, T.; KAIDA R. 2010. Functions of Xyloglucan in Plant Cells.Molecular Plant. 1-8.

HSIEH, Y. S. Y.; HARRIS, P. J. 2009. Xyloglucans of Monocotyledons have diverse structures. Molecurar Plant 1-23.

KATO Y.; NEVINS D. J. 1986. Fine structure of $(1 \circledast 3),(1 \circledast 4)-b-D-g l u c a n$ from Zea shoot cell-walls. Carbohydr. Res. 147:69-85

KOCH, F. C.;McMEEKIN, T.L. 1924. A new direct nesslerization micro Kjeldahl method and a modification of the Nessler-Folin reagent for ammonia, J. Am. Chem. Soc. 46 2066-2069.

KOOIMAN P.. 1960. On the occurence of amyloids in plant seeds, Acta Bot. Neerl. 9 208-219. 
KORMELINK, F. J. M.; HOFFMANN, R. A.; GRUPPEN, H.; VORAGEN, A. G. L.; KAMERLING, J. P.; VLIEGENTHART, J. F. G. 1993. Characterisation by H NMR| spectroscopy of oligosaccharides derived from alkali-extractable wheatflour arabinoxylan by digestion with endo-(1-4)-B-d-xylanase III from Aspergillus awamori. Carbohydrate Research 249: 369-382.

LAEMMLI U.K. 1970. Cleavage of structural protein during the assembly of the head of bacteriophage T4. Nature, 223, 680-685.

LI,Y.; JONES, L.;MCQUEEN-MASON. 2003. Expansins and cell growth. Current Opinion in Plant Biology, 6:603-610.

LIMA, D.U. \& BUCKERIDGE, M.S. 2001. Interaction between cellulose and storage xyloglucans: the influence of degree of galactosylation. Carbohydrate Polymers 46:157-163.

LIMA, D.U., CHAVES, R.O. \& BUCKERIDGE, M.S. 2003 Seed storage hemicelluloses as wet-end additives in papermaking. Carbohydrate polymers 52:367-373.

LIMA, D.U., LOH, W. \& BUCKERIDGE, M.S. 2004 Xyloglucan-cellulose interaction depends on the side chains and molecular weight of xyloglucan. Plant Physiology and Biochemistry 42(5):389-394.

MASLEN, S. L.; SADOWSKY, P.; ADAM, A.; DUPREE, P.; STEPHENS, E.. 2007. Oligosaccharide relative quantitation using isotope tagging and normalphase liquid chromatography/mass spectrometry. Carbohydrate Research 342: 724-735.

MITCHELL, D.J.; GROHMANN, K.; HIMMEL, M.E. 1990. Effect of the degree of acetylation on he enzymatic digestion of acetylated xylans. J. Wood Chem. Tech. 10:111-121. 
RYAN, S.E.; NOLAN, K.; THOMPSON, R.; GUBITZ, GM.; SAVAGE, A.V.; TUOHY, M.G. 2003. Purification and characterization of a new low molecular weight endoxylanase from Penicillium capsulatum. Enzyme and Microbial Technology. 33:775-785.

SAKAMOTO, T.; OGURA, A.; INUI, M; TOKUDA, S; HOSOKAWA, S.; IHARA, H; KASAI, N. 2009. Identification of a GH62 a-I-arabinofuranosidase specific for arabinoxylan produced by Penicillium chrysogenum. Applied Microbiology and Biotechnology Volume 90, Number 1 ,

SILVA, C. O. 2001. Papel da $\beta$-galactosidase no mecanismo de degradação do xiloglucano de parede celular durante a mobilização de reserva em cotilédones de Copaifera langsdorffii. Dissertação (Mestrado em Biologia Celular e Estrutural) - Universidade Estadual de Campinas.

SILVA, G. B. ; IONASHIRO, M. ; CARRARA, T. B. ; CRIVELLARI, A. C. ; TINÉ, M. A. S. ; PRADO, J. ; CARPITA, N. C. ; BUCKERIDGE, M. S. 2011. Cell wall polysaccharides from fern leaves: Evidence for a mannan-rich Type III cell wall in Adiantum raddianum. Phytochemistry, v. 72, p. 2352-2360.

SOCCOL, C. R.; VANDENBERGHE, L. P. DE S.; MEDEIROS, A. B. P.; KARP, S. G.; BUCKERIDGE, M.; RAMOS, L. P.; PITARELO, A. P.; FERREIRA-LEITÃO, V.; GOTTSCHALK, L. M. F.; FERRARA, M. A.. Bioethanol from lignocelluloses: Status and perspectives in Brazil. Bioresource Technology, v. 101, p. 4820-4825, 2010.

SØRENSEN HR; JØRGENSEN CT; HANSEN CH; JøRGENSEN Cl; PEDERSEN S, MEYER AS. 2006 A novel GH43 alpha-L-arabinofuranosidase from Humicola insolens: mode of action and synergy with GH51 alpha-Larabinofuranosidases on wheat arabinoxylan. Appl Microbiol Biotechnol. Dec;73(4):850-61. 
SOUSA, C. R. 2011. Caracterização da Mobilização dos Polissacarídeos da Parede Celular em Palhada de Cana-de-açúcar submetidas às condições de campo. Dissertação (Mestrado em Biotecnologia) - ICB-USP.

TJEERDSMA, B..F., MILITZ, H. (2005) Chemical changes in hydrothermal treated wood: FTIR analysis of combined hydrothermal and dry heat-treated wood. Holz als Roh- und Werkstoff. 63:102-111

TINÉ M. A.; LIMA D. U.; BUCKERIDGE M. S. 2003. Galactose branching modulates the action of cellulose on seed storage xyloglucans. Carbohydrate Polymers 52 135-141.

TINÉ, M.A.S., SILVA, C.O., LIMA, D.U., CARPITA, N.C. \& BUCKERIDGE, M.S. 2006. Fine structure of a mixed-oligomer storage xyloglucan from seeds of Hymenaea courbaril Carbohydrate Polymers 66: 444-454.

VAN GOOL, M.P.; VANCSÓ, I., SCHOLS; HA., TOTH, K.; SZAKACS, G.; GRUPPEN, H. 2011. Sceening for distinct xylan degrading enzymes in complex shake flask fermentation supernatants. Bioresource Technology 102:60396047.

VINCKEN, J-P; KEIZER, A.; BELDMAN, G.; VORAGEN, A. G. J. 1995. Fractionation of xyloglucan fragmentes and their interaction with cellulose. Plant Physiol 108: 1579-1585. 
Anexo 


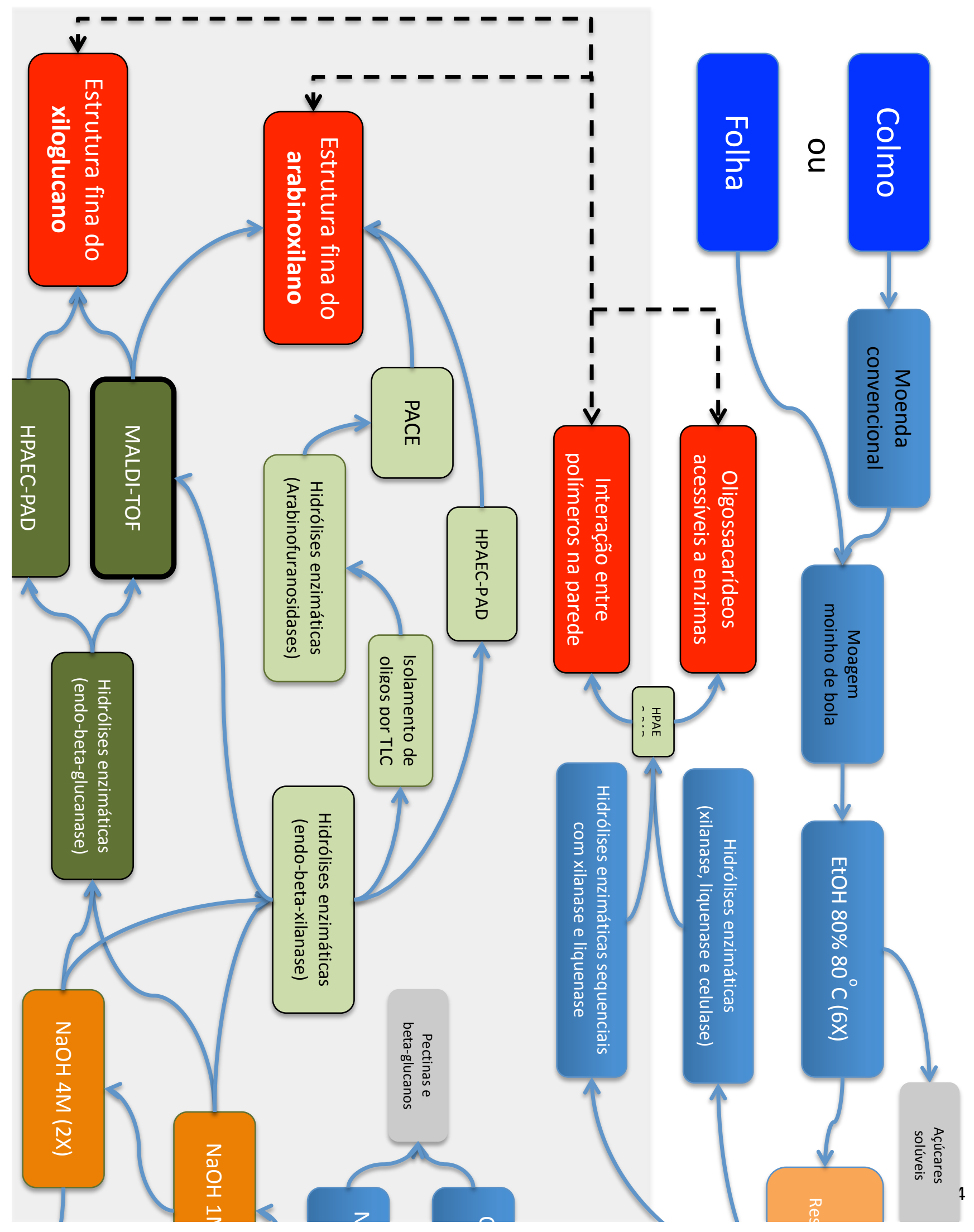


Figura 19: Esquema de todos os experimentos realizados. 